PROPERTY OF LIBRARY, DEPARTMENT OF AGRICULTURE, WEST BLOCK, OTTAWA

\title{
A SUMMARY OF THE
}

PREVALENCE OF PLANT DISEASES

IN THE

DOMINION OF CANADA

1920-1924

COMPILED BY

F. L. DRAYTON, B.S.A.

PLANT PATHOLOGIST

OTTAWA

630.4

C212

DOMINION OF CANADA

DEPARTMENT OF AGRICULTURE

BULLETIN No. 71-NeW SERIES

DIVISION OF BOTANY

DOMINION EXPERIMENTAL FARMS

$B \neg 1$

new ser.

Printed by direction of the Hon. W. R. Motherwell, Minister of Agriculture Ottawa, 1926 


\title{
DOMINION EXPERIMENTAL FARMS
}

\author{
E. S. ARCHIBALD, Director
}

\section{DIVISION OF BOTANY}

\section{H. T. GÜssOW, Dominion Botanist}

\section{ECONOMIC BOTANY}

Botanists...

J. Adams

H. Groh

Junior Botanist and Librarian.

R. A. Inglis

\section{PLANT PATHOLOGY}

Central Laboratory, Ottawa:

Plant Pathologists............................... L. Drayton

J. B. MacCurry

A. W. McCallum

Assistant Plant Pathologist.

Irene Mounce

Charlottetown, P.E.I.

Assistant Plant Pathologist....................... R. Hurst

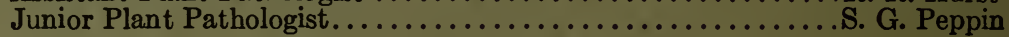

Kentville, N.S.

Plant Pathologist............................... Fockey

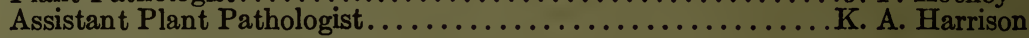

Fredericton, N.B.

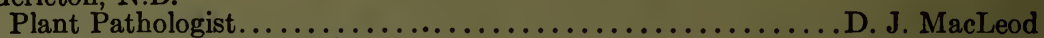

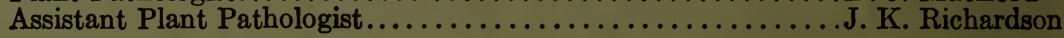

Ste Anne de la Pocatière, Que.

Plant Pathologist................................... Racicot

St. Catharines, Ont.

Senior Plant Pathologist. .......................... Herkeley

Assistant Plant Pathologists............................. Jackson

Winnipeg, Man.

G. C. Chamberlain

Senior Plant Pathologist............................. Bailey

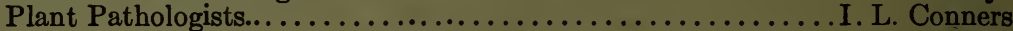

V. H. Craigie

Margaret Newton

Assistant Plant Pathologists.

F. J. Greaney

W. L. Gordon

Saskatoon, Sask.

T. Johnson

Senior Plant Pathologist. ........................ Vacant

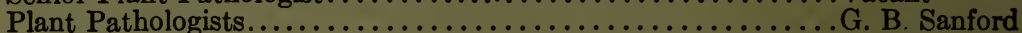

Pla P. Simmonds

Assistant Plant Pathologists....................... A. Scott

Summerland, B.C.

R. C. Russell

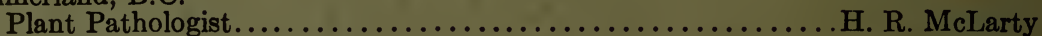

Assistant Plant Pathologist.......................... Woolliams 


\section{TABLE OF CONTENTS}

Introduction

Collaborators

Diseases of Cereal Crops.

Diseases of Forage and Fibre Crops.

Diseases of Fruit Crops.

Diseases of Vegetable and

Diseases of Forest and Shade Trees

Diseases of Ornamental Plants.

Diseases of Miscellaneous Plants.

\section{APPENDICES}

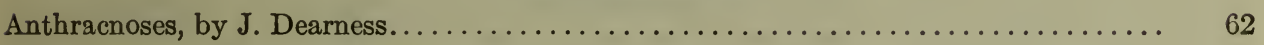

The Parasitic Fungi found in Manitoba, by G. R. Bisby, D. L. Bailey, and I. L. Conners. . 77

Index. ... 



\section{A Summary of the Prevalence of Plant Diseases in the Dominion of Canada, 1920-1924}

\section{INTRODUCTION}

A plant disease survey functions as an intelligence service for plant pathology. Information on the geographical distribution of the plant diseases of a country is gradually built up, the economic importance of each disease is recorded, their spread or stationary character in any given locality can be traced, their prevalence and dates of occurrence in successive years can be noted and often correlated with the prevailing weather conditions. Notes are also made on observed differences in varietal susceptibility and resistance. It serves as a medium for recording the appearance of diseases new to the country and stimulates a keenness for the observation of new diseases. It aids in the selection of problems for study, especially for anyone who is new to a district; and indicates the problems which require special demonstrations and extension work relative to control measures. Lastly, it helps to educate the public on the importance of plant diseases, thereby assisting in the granting of money for research and extension work leading to the formulating of control measures and their adoption.

It is obvious that the information required for a plant disease survey of any country cannot be collected by any one institution. In Canada, the Dominion Plant Pathological Service is the obvious medium for the collection and publication of such a survey, but the members of its staff are necessarily too few in number to make the survey in any way comprehensive and we have been fortunate in obtaining active co-operation from other sources in the collection of data. These include provincial institutions in which plant pathological and botanical work is being conducted, a privately endowed university, Dominion Experimental Farms and Stations, and certain private individuals who are capable of giving reliable information. We have a country of immense size, comparatively thinly populated, and at the best the number of collaborators with sufficient knowledge of plant diseases to supply information for such a survey is necessarily small, in proportion with the area to be covered, but we feel that a good start has been made, and as time goes on, these conditions will improve and the value of the survey will become cumulative.

We would like to take this opportunity to express our great appreciation of the assistance which is being given to the Division of Botany by workers outside of its staff, in the collection of data which serve as the basis of the survey. The names of the collaborators who are responsible for the material incorporated in this survey of the years 1920 to 1924 inclusive, are listed at the end of this introduction.

In this first printed publication dealing with the prevalence of plant diseases in Canada, it would seem fitting to briefly describe the history of this work. It started as the result of action taken by the Canadian Branch of the American Phytopathological Society at its first annual meeting in Guelph in 1919. Messrs. W. P. Fraser and W. H. Rankin, at that time members of the staff of the Division of Botany, were appointed a committee to undertake this work if the necessary authority could be obtained. This was readily granted by the Dominion Botanist, Mr. H. T. Güssow, and with the help of the members of the society and others interested, mimeographed annual reports were published covering the years 1920 and 1921. Dr. Rankin left the Division of Botany in 1922, and the work was transferred to the Central Laboratory at Ottawa and placed in the Author's charge. Since then the third and fourth annual mimeographed reports have been published, and this service is now a permanent part of the routine work of the Division of Botany. 
During the preparation of the fifth annual report, it was thought advisable to give a more permanent form to each quinquennial report by its publication in print, summarizing the information collected during the preceding five years.

In the arrangement of this summary, the host plants have been grouped; these groups and the number of host plants and diseases dealt with in each are as follows:-

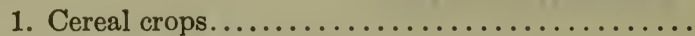

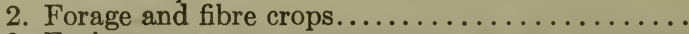

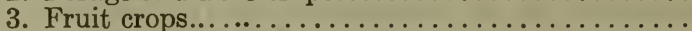

4. Vegetable and field crops....................

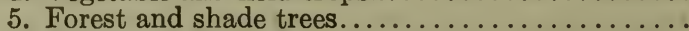

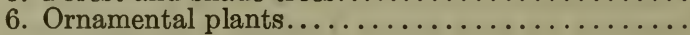

7. Miscellaneous plants....................

Total...........................

\begin{tabular}{cc} 
Host Plants & Diseases \\
4 & 55 \\
16 & 55 \\
13 & 100 \\
22 & 136 \\
19 & 61 \\
23 & 44 \\
106 & 131 \\
\hline 203 & 582
\end{tabular}

Under each host plant the diseases are dealt with in the following order:-

1. Those caused by fungi.

2. Those caused by bacteria.

3. The virus diseases and those of physiological and climatic origin.

This publication also contains two appendices which are valuable contributions to our knowledge of the plant diseases occurring in Canada. They are as follows:-

I. The Anthracnoses, prepared by John Dearness, of London, Ontario.

II. The Parasitic Fungi of Manitoba, prepared by Messrs. G. R. Bisby, D. L. Bailey, and I. L. Conners, of Winnipeg, Manitoba.

\section{British Columbia-}

\section{COLLABORATORS}

P. A. Boving, University of British Columbia, Vancouver.

A. T. Davidson, Court House, Vancouver.

J. W. Eastham, Department of Agriculture, Vancouver.

R. Glendenning, Entomological Laboratory, Agassiz.

H. R. McLarty, Dominion Laboratory of Plant Pathology, Summerland.

E. M. Straight, Dominion Experimental Station, Saanichton.

C. Tice, Department of Agriculture, Victoria.

Alberta-

W. D. Albright, Dominion Experimental Station, Beaver Lodge.

A. H. Brinkman, Craigmyle.

G. H. Cutler, University of Alberta, Edmonton.

G. E. DeLong, Dominion Experimental Station, Lacombe.

W. H. Fairfield, Dominion Experimental Station, Lethbridge.

Saskatchewan-

W. P. Fraser, University of Saskatchewan, Saskatoon.

C. H. Holmes, formerly of Dominion Laboratory of Plant Pathology, Saskatoon.

H. S. MacLeod, Dominion Laboratory of Plant Pathology, Saskatoon.

C. E. Maguire, Dominion Laboratory of Plant Pathology, Saskatoon.

R. C. Russell, Dominion Laboratory of Plant Pathology, Saskatoon.

J. W. Scannell, Dominion Laboratory of Plant Pathology, Saskatoon.

H. A. Scott, formerly of Dominion Laboratory of Plant Pathology, Saskatoon.

P. M. Simmonds, Dominion Laboratory of Plant Pathology, Indian Head.

J. C. Taggart, Dominion Experimental Station, Swift Current.

Manitoba-

D. L. Bailey, Dominion Laboratory of Plant Pathology, Winnipeg.

G. R. Bisby, Manitoba Agricultural College, Winnipeg.

I. L. Conners, Dominion Laboratory of Plant Pathology, Winnipeg.

J. H. Craigie, Dominion Laboratory of Plant Pathology, Winnipeg.

F. J. Greaney, Dominion Laboratory of Plant Pathology, Winnipeg.

V. W. Jackson, Manitoba Agricultural College, Winnipeg.

W. R. Leslie, Dominion Experimental Station, Morden. 
Ontario-

G. H. Berkeley, Dominion Laboratory of Plant Pathology, St. Catharines.

G. C. Chamberlain, Dominion Laboratory of Plant Pathology, St. Catharines.

R. F. Crossgrove, Dominion Laboratory of Plant Pathology, St. Catharines.

J. Dearness, London.

D. D. Digges, Dominion Experimental Station, Harrow.

F. L. Drayton, Division of Botany, Ottawa.

J. H. Faull, University of Toronto, Toronto.

H. Groh, Division of Botany, Ottawa.

H. T. Güssow, Division of Botany, Ottawa.

J. E. Howitt, Ontario Agricultural College, Guelph.

A. B. Jackson, Dominion Laboratory of Plant Pathology, St. Catharines.

W. T. MacClement, Queen's University, Kingston.

J. B. MacCurry, Division of Botany, Ottawa.

T. G. Major, Tobacco Division, Ottawa.

A. W. McCallum, Division of Botany, Ottawa.

Irene Mounce, Division of Botany, Ottawa.

G. Partridge, Division of Botany, Ottawa.

W. H. Rankin, formerly of Dominion Laboratory of Plant Pathology, St. Catharines.

A. G. Richmond, Dominion Laboratory of Plant Pathology, St. Catharines.

D. R. Sands, Ontario Agricultural College, Guelph.

C. M. Slagg, Tobacco Division, Ottawa.

R. E. Stone, Ontario Agricultural College, Guelph.

J. Tucker, c/o Ontario Agricultural College, Guelph.

Quebec-

B. Baribeau, Dominion Laboratory of Plant Pathology, Ste Anne de la Pocatière.

P. E. Bryce, formerly of Macdonald College.

F. S. Browne, Dominion Experimental Station, Lennoxville.

J. H. Coulson, Macdonald College.

B. T. Dickson, Macdonald College.

K. A. Harrison, Macdonald College.

M. D. McCharles, Dominion Experimental Station, Lennoxville.

A. McTaggart, Macdonald College.

H. N. Racicot, Dominion Laboratory of Plant Pathology, Ste Anne de la Pocatière.

T. C. Vanderpool, Macdonald College.

New Brunswick-

A. A. Brown, Dominion Laboratory of Plant Pathology, Fredericton.

G. C. Cunningham, formerly of Dominion Laboratory of Plant Pathology, Fredericton.

C. H. Godwin, Dominion Laboratory of Plant Pathology, Fredericton.

D. J. MacLeod, Dominion Laboratory of Plant Pathology, Fredericton.

J. K. Richardson, Dominion Laboratory of Plant Pathology, Fredericton.

Nova Scotia-

W. W. Baird, Dominion Experimental Farm, Nappan.

S. A. Hilton, Dominion Experimental Farm, Nappan.

J. F. Hockey, Dominion Laboratory of Plant Pathology, Kentville.

A. Kelsall, Dominion Entomological Laboratory, Annapolis Royal.

W. K. McCulloch, Dominion Laboratory of Plant Pathology, Kentville.

S. C. Partridge, formerly of Dominion Laboratory of Plant Pathology, Kentville.

R. J. Robertson, Dominion Experimental Farm, Nappan.

Prince Edward Island-

R. Creed, Dominion Laboratory of Plant Pathology, Charlottetown.

E. W. C. Foster, formerly of Dominion Laboratory of Plant Pathology, Charlottetown.

J. L. Howatt, Dominion Laboratory of Plant Pathology, Charlottetown.

R. R. Hurst, Dominion Laboratory of Plant Pathology, Charlottetown.

G. O. Madden, formerly of Dominion Laboratory of Plant Pathology, Charlottetown.

J. Mustard, formerly of Dominion Laboratory of Plant Pathology, Charlottetown.

S. G. Peppin, Dominion Laboratory of Plant Pathology, Charlottetown. 


\section{DISEASES OF GEREAL GROPS}

\section{WHEAT}

Stem Rust-Puccinia graminis Pers.

British Columbia.-Of little importance. The amount of wheat grown is comparatively small, the average annual yield for the five-year period 1918-22 being 980,800 bushels. A small amount of rust was reported from the mixed farmins districts in 1923. Eastham states that no barberries were found in this region, which may account, in part at least, for the comparative freedom from the disease.

Alberta.-A small amount was reported each year during the five-year period. In 1923, it was most prevalent, the areas in which it had been reported in previous years being much extended; the infection, however, was too late to make much reduction in the yield. In 1920 the date of the earliest reported infection on wheat was August 12, and in 1921, August 16. The average annual yield for the five-year period 1918-22 was 51,961,600 bushels, and the yield for 1923 was $166,834,000$ bushels.

Saskatchewan.-This province produces the largest amount of wheat in the Dominion, the average yield for the five-year period 1918-22 being 146,757,860 bushels, and the yield for 1923 was $252,622,000$ bushels.

During the five-year period under review, there was great variation in the prevalence of stem rust and in the losses incurred. It was worst in 1923, when the late crops, especially, suffered severely, resulting in a loss estimated at 20 per cent or over $60,000,000$ bushels. In 1922 and 1924 , the losses were negligible, due largely to the dry weather during July and August. In 1920 the late grain was badly infected, but the damage was small. An unusual feature of the 1921 infection was its localized nature. It was severe in the south and east, resulting in some loss, but in the north, the dry weather in August checked its development.

The dates of the first appearance of this disease on wheat were as follows:-

1920

July 9

1921

July 5

1922

July 12

1923

July 11

1924

July 29

Manitoba.-The frequency with which serious stem rust attacks occur in the Red River Valley makes this province the most important in dealing with a survey of this disease, and each year in the five-year period will be reviewed separately. The average annual yield for the five years 1918-22 was 45,162,680. bushels.

1920

The total yield was $37,542,000$ bushels. Stem rust developed during July and the first week in August, becoming abundant and causing considerable damage to the late planted wheat. It did not develop as rapidly in the west as it did in the Red River Valley, there being only traces in the west until July 19, when a week of rainy weather led to abundant development and some loss to late wheat in local areas.

1921

The total yield was $39,054,000$ bushels. From observations made in various parts of the province the general trend of the infection was first in the west and later in the east. The loss was estimated at 15 per cent, or nearly $7,000,000$ bushels.

1922

The total yield was $60,051,000$ bushels. The distribution was strikingly irregular, there being no way of accounting for its presence in some localities and absence in others. The losses were small. 
1923

The total yield was $32,804,000$ bushels. Spring floods delayed the seeding, the temperature was high during July, and by July 18, in the central and southern sections, infection was universal and the severity as high as 70 to 80 per cent. Throughout the province it was serious, resulting in a loss of 50 per cent of the crop or a reduction in yield of over $30,000,000$ bushels. This was the worst year since 1916.

1924

The total yield was $45,000,000$ bushels. Both wheat and rust were late. In the latter half of July, conditions were ideal for rust development, by July 26 it was general, and it seemed as if a repetition of the 1923 epidemic was inevitable. However, weather conditions changed in August, the rainfall remaining abundant, but the temperature much lower, thus providing conditions somewhat more favourable for the wheat than for the rust. In addition, conditions in the earlier part of the season had resulted in a limited growth of the wheat, composed of hard straw, which probably had some effect in limiting the subsequent development of the rust.

The infection generally was localized and there was some loss, but it was small compared with 1923. The reduction in yield was estimated at 10 per cent or a loss of $5,000,000$ bushels.

The dates of the first appearance of this disease on wheat were as follows:-

$\begin{array}{ccccc}1920 & 1921 & 1922 & 1923 & 1924 \\ \text { June } 30 & \text { June } 27 & \text { July } 3 & \text { July } 6 & \text { July } 16\end{array}$

Ontario.-The average annual yield for the five years 1918-22 was 18,876,000 bushels, and the yield for 1923 was 18,537,000 bushels.

The survey of this province was not extensive, but the reports received indicated that, in the northern sections, the damage was more severe. The central and eastern counties have been free from serious loss. In the southwestern peninsula it was prevalent in 1921 and 1923, but the loss, generally, was slight. In the province as a whole it was least prevalent in 1924 .

Quebec.-The average annual yield for the five years 1918-22 was 3,865,800 bushels, and the yield for 1923 was 1,194,000 bushels.

Occasional severe outbreaks, such as in Matane and Sherbrooke in 1923, were reported, but on the whole, the recorded loss from this disease was slight.

New Brunswick.-The average annual yield for the five years 1918-22 was 570,130 bushels, and the yield for 1923 was 275,000 bushels. The reports indicated that stem rust was rarely of economic importance, its prevalence in 1921 and 1922 being decidedly less than in the other years.

Nova Scotia.-The average annual yield for the five years 1918-22 was 469,900 bushels, and the yield for 1923 was 239,000 bushels. Stem rust is of common occurrence, but rarely severe. In 1923, a severe local attack occurred at Piedmont and Merigomish.

Prince Edward Island.-The average annual yield for the five years 1918-22 was 589,060 bushels, and the yield for 1923 was 575,000 bushels.

In 1920 the disease was most severe, causing considerable loss in Prince county, with a moderate loss in Queen's county, and practically no loss in King's county. On account of the dry weather in 1921, there was little or no damage, and in the other years, there were general, moderate infections with slight losses.

LEAF RUST-Puccinia triticina Eriks.

Reported from every province except British Columbia. In 1920 it was of no importance in the Prairie Provinces, while in the east it was severe, and caused considerable leaf injury. In 1921, however, wheat in Saskatchewan and Manitoba was seriously injured, being the worst attack experienced for a number of years. The loss was estimated at 2 per cent. In 1922, 1923, and 1924, it 
was general, but losses in the west were by no means as great as in 1921 . The fall wheats and Kota are apparently more susceptible than the commonly grown varieties of spring wheat.

Bunt or Strnking Smut—Tilletia laevis Kühn and Tilletia Tritici (Bjerk.) Wint.

Although reported from every province except Nova Scotia the losses were never great, formalin seed treatment giving good control.

There was a striking difference between the years 1922 and 1923 in its occurrence in the West. In the former, conditions were evidently suitable for its development, as shown in untreated fields and check plots in experimental work, where considerable occurred; in the latter year, it was unusually rare even in fields where the seed had not been treated.

Loose Smut-Ustilago Tritici (Pers.) Jens.

This caused much greater loss than the stinking smut. It occurred in every province and was somewhat more prevalent in the East than in the West. In Manitoba the infections were general each year, but the losses rarely exceeded 2 per cent; here, the variety Kota is apparently more susceptible than Marquis. The largest loss was reported from Kamouraska county, Quebec. In Prince Edward Island it was present, generally, during the five years, and losses from 1 to 3 per cent were reported.

Engot-Claviceps purpurea (Fr.) Tul.

Of little or no importance. Its presence was reported from the Prairie Provinces, New Brunswick, and Prince Edward Island. In Alberta and Saskatchewan there was more of it than usual in 1923, but it was by no means general.

ScAB-Gibberella Saubinetii (Mont.) Sacc.

Reported from all the provinces except British Columbia, Alberta, and Nova Scotia. At Winnipeg, in 1921, the variety Ruby had 10 per cent of the plants affected, other varieties showed much less. In Manitoba, in 1923, Messrs. Bisby and Bailey found the perfect stage on old corn stalks. It was not a serious disease, the infections were never general nor the losses appreciable.

PoWdery MILDEw-Erysiphe graminis DC.

Reported from Alberta, Saskatchewan, Ontario, Quebec, and Prince Edward Island. It was not destructive. In 1923, at Macdonald College, there was a bad outbreak, this being the only severe infection reported, although each year there was some present.

Glume Blotch-Septoria nodorum Berk.

British Columbia was the only province from which it was not reported. In 1923 it was bad in the Prairie Provinces, the Red River Valley in Manitoba being the only district in which no specimens could be found. In New Brunswick it was reported as one of the chief causes of poor crops during the period 1920 to 1922. Here, Dawson's Golden Chaff exhibited resistance. Some loss undoubtedly occurred where the infection was bad, but these were infrequent and scattered.

Leaf Spот-Septoria Tritici Desm.

One report received from Manitoba in 1924, where it was common and occasionally severe, especially on the lower leaves. The damage was slight.

STRIPE Rust-Puccinia glumarum (Schum.) E. et H.

It was found at Stettler, Alberta, in 1920, on Hordeum jubatum, and in 1919 , on the same host at Edmonton. On both occasions, attempts were made to infect wheat in the greenhouse, but without success. 
TAKE ALL-Ophiobolus cariceti (Berk. et Br.) Sacc. (=Ophiobolus graminis Sacc.) The first report was in 1923 , when a severe infection was found in a field in Northern Saskatchewan. In 1924 it was found again in the same province, in the district of Annaheim, where it was present on 10 per cent of the plants.

Fоот Roт—Wojnowicia graminis (McAlp.) Sacc. et D. Sacc.

Late in the fall of 1924 a field at Senlac, Saskatchewan, was reported to be attacked by foot rot. Mr. Hurst collected stubble from the diseased areas. On the base of the stems and the adhering sheaths, the pycnidia of Wojnowicia graminis were present. This fungus was later found to be associated with the Ophiobolus foot rot. This suggested that it may be the pycnidial stage of the Ophiobolus. The growth in culture, however, is so different, that it does not seem probable that it is related.

Pathogenic studies in the laboratory by Mr. Russell indicated that it is a weak parasite, but the studies were not extensive enough to draw definite conclusions.

On the host, this fungus resembles Ophiobolus cariceti in the massing of dark mycelium, and the beaked conidia bear a close resemblance to the perithecia of Ophiobolus. The pycnidia usually develop more abundantly in the free leaf sheaths than the perithecia of Ophiobolus, and are surrounded by loose wefts of mycelium. The presence of bristles around the ostiole of the pycnidium is also a distinguishing character. (W. P. Fraser.)

Head Blight and Foot Rot-Helminthosporium sativum P. K. et B.

Noted in the three Prairie Provinces. In 1921, in Manitoba, it caused considerable leaf injury and the plants were attacked so early that the heads never filled. In Saskatchewan, in 1922, it was common on stems and heads, causing a blight and rot of the base of the stems, especially on the Durum wheats. In Alberta it has not caused much damage, but in 1923 it was common, especially as a foot rot, in a number of fields.

Root and Foot Rots-Fusarium and Helminthosporium spp.

Occurred in the Prairie Provinces. In 1924 they were more common than usual, infections ranging from 2 to 20 per cent.

Mr. Oval Fleming, writing to the Canadian Pacific Railway Agricultural Department, stated, "Wheat root rots caused the farmers near Aldair, Saskatchewan, thousands of dollars loss this year."

FUSARIUM Blight-Fusarium spp.

Reported from Alberta and Saskatchewan in 1923 and 1924. It was prevalent but not severe.

\section{Bacterial Diseases}

Basal Glume Rot—Bacterium atrofaciens McCulloch.

Reported from the Prairie Provinces in each of the five years, 1921 and 1923 being the worst years, when as high as 5 per cent of the plants in various fields were affected. At Lacombe, Alberta, the varieties worst affected were Red Bobs, Early Red Fife, and Early Triumph.

BLACK ChAFF-Bacterium translucens undulosum S.J. et R.

No reports were received until 1923, when some specimens were collected in Manitoba, where slight damage resulted. It occurred in this province again in 1924, the damage being about the same as that of the previous year.

KRINKLE JOINT

NON-PARASITIC DISEASES

This is marked by a kink or abrupt bend on the lower internodes of the stem. As the plants mature, the stem breaks at this point and the plants fall over. In 
Saskatchewan, this was found especially on the varieties Major and Preston in 1922 and 1923. It was also observed at Lacombe, Alberta, and the surrounding districts in 1922.

White Tip

In 1921 and 1923, it was prevalent in the drought affected districts of Manitoba, and in 1924 in Saskatchewan.

Frost InJury

The only report of this type of injury was to late wheat in Northern Manitoba in 1924, where there was considerable loss.

\section{OATS}

Stem Rust-Puccinia graminis Pers.

It occurred in every province except British Columbia.

Alberta.-The outstanding year was 1921 when it was common in the wheat stem rust areas, resulting in serious damage. There were trace infections during the other years, but it was of little importance.

Saskatchewan.-In this province, also, the damage was serious in 1921. During the other years it lessened the yield of late oats in some localities.

Manitoba.-In 1923 it was late in making its appearance. July 19, as compared with June 27 in 1921, when the loss was estimated at 5 per cent. In general it was the late oats only which suffered any appreciable loss.

Ontario.-Reports indicate losses every year, particularly in 1922, when some of the late oats were worthless except for green feed.

Quebec.-Such early varieties as Daubeney and Alaska evidently escaped injury, but there was considerable loss in the later varieties.

New Brunswick.-Reported as consistently present during the five years, the damage being somewhat worst in 1922 .

Nova Scotia.- Heavy losses in isolated areas were reported, but on the whole it was not responsible for much damage.

Prince Edward Island.-It was general in its occurrence, but not severe or causing much loss.

Leaf or Crown Rust-Puccinia coronata Cda.

Reported from every province, except British Columbia. In the Prairie Provinces it was of little importance in Alberta, but in the other two provinces it was consistently severe in fields adjoining buckthorns. In Ontario and Quebec it caused greater losses than the stem rust, being severe on late oats. In the Maritime Provinces it was of general occurrence but not injurious.

Smuts-Ustilago levis (K. et S.) Magn. and Ustilago Avenae (Pers.) Jens.

These are by far the most destructive of the cereal smuts. They occur in all of the provinces, the amount depending on whether the seed oats were treated or not.

British Columbia.-They were general. In 1923 infections as high as 40 per cent with an average of 5 per cent were reported. The covered type evidently predominated.

Alberta.-Found as far north as Beaverlodge in the Peace River district. Losses during the five years ranged from a trace to 15 per cent in various localities.

Saskatchewan.- The covered type was more common than the loose. The worst year was 1923 when infections as high as 25 per cent were reported; the average of the other years was about 2 per cent.

Ontario.- It was bad in the northwestern sections in 1922 and 1923; infections as high as 20 per cent were reported. The province as a whole suffered an average loss of about 1 per cent during the five years.

Quebec.-Moderate infections occurred in all the years except in 1924 when they were unusually prevalent, with an average of 6 per cent loss reported. 
New Brunswick.- Some fields planted with untreated seed showed as high as 25 per cent infection, but an average loss for the five years would not exceed 3 per cent.

Nova Scotia.-Liberty (hulless) oats showed marked susceptibility. The smuts occur fairly generally with infections ranging from 5 to 20 per cent.

Prince Edward Island.-Generally present and destructive; losses average about 2 per cent.

ScAB-Gibberella Saubinetii (Mont.) Sacc.

Reported from New Brunswick only. First noted in 1920 at the Fredericton Experimental Station where as high as 5 per cent was found in the plots. In 1922 , out of 25 fields examined, 5 showed infections of 5 to 1 per cent, not serious. PowDERY MILDEw-Erysiphe graminis DC.

The only report is from Macdonald College, Quebec, where a severe infection occurred in 1923.

Anthracnose-Colletotrichum cereale Manns.

One report from Saskatchewan in 1923, when it was found in the south. The nodes and bases of the leaves were most affected. At Indian Head 60 per cent of the plants were affected. It was less severe and common in other districts.

LeAF Sрот BцотCH-Leptosphaeria avenaria Weber.

Found at the Brandon Experimental Farm, Manitoba, in 1923 by Mr. Conners. Typical conidia of Septoria Avenae Frank were found scattered among the telia of crown rust. An ascomycete agreeing with Weber's description of Leptosphaeria avenaria was also found. This observation was corroborated by Dr. Bisby.

Leaf Discoloration-Helminthosporium sp.

Reported from Saskatchewan and Ontario in 1924. In Essex county from one to six lesions per leaf on every plant in twelve fields were found. In Saskatchewan it was found at Buchanan in 1924 and in 1923 it was common in the southern sections of the province.

Root Rot-Fusarium sp.

In 1920 it was found at Edmonton, Alberta, and severe in a small plot at Saskatoon, Saskatchewan. In 1924 it was reported as general in parts of Manitoba, 2 per cent of infected plants being common.

Halo Blight-Bacterium coronafaciens Elliott

Reported from the three Prairie Provinces, where it is occasionally common, but not causing much loss.

In 1924, at Brandon, Manitoba, all varieties showed a bacterial leaf spot which Conners thinks is distinct from halo blight. He states: "Bacterial crusts on the epidermis at the centre of the infections were quite noticeable. The spots were more oval than those of halo blight, and apparently the veins did not limit the diseased areas in the same way. Alaska, an early variety, showed 5 per cent of the leaf surface affected in the early part of the season, with other varieties about 2 per cent. Later in the season new growth showed no sign of the disease and apparently little damage was done."

\section{LEAF BLight}

\section{Non-Parasitic Diseases}

In the rotation experimental plots at the Central Experimental Farm, Ottawa, one field has failed to yield healthy oat plants during a period of eleven years. In the early summer of 1923 the diseased condition again appeared. When the plants are four or five inches high, the leaves develop pale patches with brown or reddish edges and finally droop and wither. Large dead areas occurred in the field, which quickly became filled with weeds, principally Poly- 
gonum pennsylvanicum. This apparently is the same disease as the one described in Europe as "Grey Speck" or "Yellow Tip". Vide abstracts in the Review of Applied Mycology, Vol. I, pp. 417 and 421. Dr. Dickson reported a similar disease occurring in the oat plots at Macdonald College in the same year. The losses there ranged from 20 to 80 per cent in the affected plots.

\section{Blasting of Heads}

The panicles contain a number of sterile flowers, the glumes of which are white and dead. Varying amounts of this were reported from Saskatchewan and Manitoba. In Prince Edward Island it was of fairly general occurrence in 1924 , but not causing much loss.

\section{BARLEY}

Loose Smut—Ustilago nuda (Jens.) K. et S.

Reported from every province except Nova Scotia. It was quite common in the Prairie Provinces, the greatest losses occurring in 1920. At Beaverlodge, in northern Alberta, it was prevalent, but good results were obtained from the hot water treatment. In a variety test at Brandon, Manitoba, in 1924, the varieties Junior, O.A.C. No. 21, Chinese Ottawa No. 60, and Beaver were apparently most susceptible. In Ontario and Quebec it occurred to a small extent in most barley fields. In Prince Edward Island it was general and in some fields severe.

Covered Smut-Ustilago Hordei (Pers.) K. et S.

It was not reported from the Maritime Provinces or British Columbia. In the Prairie Provinces it was general but not as common as the loose smut. Infections ranged from a trace to 5 per cent, with occasional fields having 10 per cent.

In Ontario and Quebec, occasional infections were noted, the average being about 1 per cent, the exception being in Frontenac county, in 1921, where it was more prevalent than usual, about 5 per cent loss.

Stem Rust-Puccinia graminis Pers.

No reports were received from British Columbia, Nova Scotia, or New Brunswick. In the Prairie Provinces it was common during the five years and developed abundantly, but usually the crop matured before any serious damage had occurred. In Ontario and Quebec occasional severe attacks were found but the damage on the whole was slight. In Prince Edward Island it was common, but of no importance.

LeAF Rust-Puccinia simplex (Koern.) Eriks. et Henn.

It was found at Winnipeg, Manitoba, in 1922, but no specimens could be found in the following years. A slight infection was reported from Ontario and Quebec in 1920.

Stripe Rust-Puccinia glumarum (Schm.) Eriks. et Henn.

Prior to 1924, collections were made by Mr. Fraser at a number of points in Alberta on Hordeum jubatum. In 1924, C. E. Maguire made collections of barley leaves at Vermilion, Alberta, which had netted blotch; the rust was not found on this material until a careful examination was made of it in the winter, so that a survey of its prevalence could not be made in this district. This is the only report of this rust on cereals in Canada.

STRIPE-Helminthosporium gramineum Rab.

It occurred every year in the Prairie Provinces. In 1920 it was the worst barley disease, and in 1924 it was much less than usual, only being found occasionally. In the other years it was fairly common, but of little importance.

It was also reported from Ontario, Quebec, Nova Scotia, and Prince Edward Island, but the observations were too few to draw any conclusions as to losses. 
Net Blotch-Helminthosporium teres Sacc.

Reported from the Prairie Provinces during each of the five years. In 1923 the worst infection occurred, as high as 50 per cent of the leaf surface destroyed in some fields. The varieties Manchurian and Stella were the most susceptible.

Sрот ВцотсH-Helminthosporium sativum P.K. et B.

So far reported only from the Prairie Provinces, being worst in Manitoba, where it was found in every barley field examined in 1921 and 1923, with infections ranging from 7 to 40 per cent. The losses on the whole were slight.

FALSE STRIPE-cause unknown

In 1924, at the Brandon Experimental Farm, Manitoba, in fifteen varieties of barley grown in one-fortieth acre plots, Mr. Conners collected what he has tentatively called "false stripe". He states: "The markings were not typical of the true stripe, caused by Helminthosporium gramineum Rab. The stripes were not limited by the veins, but tended to coalesce, forming elongated V's. The upper part of the leaf was usually a normal green, until it began to die, having been cut off from water by the lower diseased portion. The base of the leaf was usually affected all the way across, and the diseased area ran up the leaf for one-third to one-half of its length, where the stripes tapered off into the elongated V's mentioned before. Specimens collected late in the season showed heavy sporulation of Heterosporium, also the earlier collection, when placed in a moist chamber. Specimens were submitted to Mr. Fraser; he had observed the trouble but had found that inoculation with Heterosporium spores failed to infect. My observations would lead me to believe that the disease is systemic, and that possibly the Heterosporium is secondary."

"Another striking difference from the true stripe is in the abundant production of heads in diseased plants, these appearing normal and sound in every way."

"Bark's Excelsior showed 3.5 per cent and O.A.C. No. 2115 per cent, being the average of a number of counts in two plots of each variety."

LEAF SPOT-Rhynchosporium Secalis (Heins.) Davis

Reported from the provinces of Alberta and Saskatchewan. This disease is a serious one in the Mississippi Valley, and was first found in Canada at Edmonton, Alberta, in 1921. In 1922 collections were made at Edmonton again, when it was severe in spots, but not general. In 1923 it was found at Scott, Lacombe, and other districts in northern Alberta, as well as at Indian Head, Saskatchewan; at the latter, 10 per cent of the plants were affected and in some cases severely. In 1924 it was again found at Lacombe, Bark's Excelsior being markedly susceptible. In 1924 it was also found at Scott, Saskatchewan.

PowDERY MILDEW-Erysiphe graminis DC.

The only report of this was from Macdonald College, Quebec, where they had a severe infection in 1923.

ERGOT-Claviceps purpurea (Fr.) Tul.

In Manitoba it was found at Brandon and Morden in 1920 and 1923 respectively. At the latter place it was common, but not severe, 2 per cent of the plants being affected. In 1923 and 1924 it was found at Indian Head and Swift Current, Saskatchewan.

Leaf Blotch-Septoria Passerinii Sacc.

Nineteen hundred and twenty-three was the only year in which it was reported. It was common at Macdonald College, Quebec, on the leaves of some unthrifty varieties, being of no importance on any varieties which were suited to the climatic conditions.

It was general, but of little importance, in Saskatchewan, and collected at Boissevain, Manitoba.

$23056-3$ 
Dilophospora graminis Desm.

This was reported by P. M. Simmonds, who states: "In a field of barley at Carlyle, Saskatchewan, several plants were noticed to have twisted and otherwise distorted heads. A careful examination revealed on some of these heads a rather firm and distinct fungous growth, as well as a considerable number of dark spots on the leaves in which pycnidia were found. A microscopical examination revealed the presence of an unusual fungus. This was later determined by Dr. J. J. Davis, of the University of Wisconsin, as Dilophospora graminis Desm., a fungus not uncommonly occurring on grasses, but apparently it has not been reported to any great extent on cereals. The disease was not common, being present in a small area near the edge of a field, where it may have come from nearby grasses. The plants attacked, however, were severely injured."

BACterial Blight-Bacterium translucens J. J. et R.

Reported from Manitoba only, where it was observed in 1920,1923 , and 1924. It apparently did little damage.

\section{RYE}

Stem Rust-Puccinia graminis Pers.

Reported as present in Manitoba, Ontario, and Quebec. It is not of much importance, being present to a small extent on spring rye, and more severely late in the season on plants which were not harvested, and on volunteer growth.

LeaF Rust-Puccinia dispersa Eriks.

It occurred in the Prairie Provinces, Ontario, and Quebec. Infections were slight to severe, but little or no damage resulted. It was somewhat more prevalent on winter rye than on spring sown plants, but even on these plants the damage was only slight.

ERGoT-Claviceps purpurea (Fr.) Tul.

This was reported from every province except Prince Edward Island. Most of the infections were from 1 to 3 per cent with exceptional instances when 25 per cent was found.

Powdery MILDEW-Erysiphe graminis DC.

Reported from the Prairie Provinces and Quebec. It caused little or no damage, although it was abundant, especially in 1920 and 1923.

Downy Mildew-Peronospora Trifoliorum deBary

Mr. W. P. Fraser reported this disease in 1923 as quite severe on some plots at Lacombe, Alberta; not observed elsewhere.

Smut-Urocystis occulta (Wallr.) Rab.

In southern Alberta six infected heads were collected in 1921. In 1924 it was collected in Lincoln county, Ontario, and in one field south of Lake Clementi, Manitoba. 


\title{
DISEASES OF FORAGE AND FIBRE GROPS
}

\author{
ALFALFA
}

Leaf Spot-Pseudopeziza Medicaginis (Lib.) Sacc.

Reported from every province. Wherever alfalfa was grown it was apparently present, but no appreciable damage was noticed. It was more prevalent on the second growth, in some districts causing some defoliation of the lower leaves.

Rоот Roт-Sclerotinia Trifoliorum Eriks.

In British Columbia it caused severe injury to limited areas in East Kootenay and in the breeding blocks at Point Grey. A few specimens were collected in Alberta and Manitoba. In Ontario and Quebec, in 1924, 6 per cent of the plants were destroyed in breeding blocks at the Central Experimental Farm and Macdonald College respectively.

\section{Downy MiLdew-Peronospora Trifoliorum deBary}

It was found occasionally along irrigation ditches and in wet spots in British Columbia, but it is of no economic importance. It was also found in Alberta and Manitoba, causing a slight amount of yellowing of the leaves.

\section{Yellow Leaf Blotch-Pyrenopeziza Medicaginis Fckl.}

This was the most noticeable disease of alfalfa at the Brandon Experimental Farm, Manitoba, in 1923. The imperfect stage (Sporonema phacidiodes Desm.) was collected in abundance. It was apparently the cause of a small amount of leaf drop. It was also found at Indian Head, Saskatchewan, and at Winnipeg, Manitoba.

Leaf Spot—Pleosphaerulina Briosiana Pollacci

Mr. I. L. Conners states: "In 1923 a new spot was found at the Brandon Experimental Farm, Manitoba. It is characterized by a white centre with brown to black, slightly raised margin. Black perithecia were visible in the large spots (4 mm. in diameter). Dr. Bisby kindly verified the determination. This parasite has been reported in the United States Plant Disease Survey as occurring in Georgia and other southern states."

LeAF Spот-Ascochyta Medicaginis Bres. in 1923.

Messrs. Bisby and Bailey reported a trace as found in southeastern Manitoba Rust-Uromyces Medicaginis Pass.

Mr. T. G. Major states: "In Essex county, Ontario, in 1923, in one field up to ten sori were found on every leaf."

White Spot

Presumably a physiological disease and identical with the disease described by C. H. Crabhill in Phytopathology, Vol. 6, page 91 . In 1920 it was not uncommon at Winnipeg, Manitoba, early in the season. The affected plants, however, produced a good crop.

It was also reported from British Columbia and Prince Edward Island in 1921 as quite common, but apparently resulting in no damage.

\section{CLOVERS}

Powdery Mildew-Erysiphe Polygoni DC.

A Dominion-wide epidemic of this disease occurred during the years 1921 to 1924 , Alberta being the only province from which no reports were received as to its occurrence; it being described as "general," "extremely prevalent," or "present to an astonishing extent," in all the other provinces. In 1924, the reports indicated a slight reduction in its prevalence, as compared with the two years previous.

23056-3! 
While it is spectacular, it does not seem to cause much loss, although some stunting of the plants and slight reduction of seed has been observed. No cases of stock poisoning from the mildewed hay were reported. The presence of the perfect stage of the fungus has not yet been recorded in Canada, although it has been collected in a number of the western states and in West Virginia.

Decided resistance has been observed in certain strains of clovers, so that its ultimate control is possible.

\section{Rusts-Uromyces spp.}

The reports received relative to these rusts did not always indicate which species of Uromyces was concerned. Two systems of classification have been recorded, one by W. H. Davis in Phytopathology 14:33, January, 1924, and another by J. C. Arthur in the North American Flora, 7:3, pages 254-255. These are given in the following table:-

\begin{tabular}{|c|c|c|}
\hline Kind of Clover & \multicolumn{2}{|c|}{ Rusts } \\
\hline 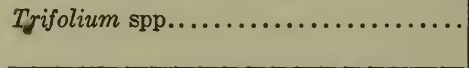 & $\begin{array}{l}\text { Davis } \\
\text { Uromyces spp. }\end{array}$ & $\begin{array}{c}\text { Arthur } \\
\text { Nigredo spp. }\end{array}$ \\
\hline 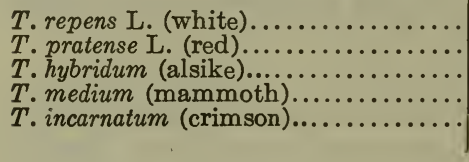 & 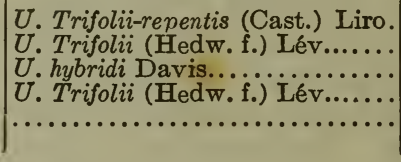 & $\begin{array}{l}\text { N. Trifolii (Hedw. f.) Arthur } \\
N . \text { fallens (Desmaz.) Arthur } \\
N . \text { Trifolii (Hedw. f.) Arthur } \\
N . \text { fallens (Desmaz.) Arthur } \\
N . \text { fallens (Desmaz.) Arthur } \\
N . \text { Trifolii (Hedw. f.) Arthur }\end{array}$ \\
\hline
\end{tabular}

These rusts have been reported from every province. Occasional killing of the leaves has been observed, but the injury on the whole is slight.

In Manitoba, aecia were found in late June and early July on white clover.

Rоoт Rot-Sclerotinia Trifoliorum Eriks.

Reported from British Columbia, where the injury was severe in limited areas; slight infections in Manitoba, and in Ontario. At the Central Experimental Farm, Ottawa, in 1924, 7 per cent of the plants were destroyed in the breeding blocks.

Leaf Spot-Pseudopeziza Trifolii Fckl.

Reported from all the provinces except the three Prairie Provinces. There was apparently little or no loss involved with these infections, except in New Brunswick in 1922, where the infections were bad enough to cause some loss in the quantity and quality of the crop.

Sooty Spot-Phyllachora Trifolii (Pers.) Fckl.

It is frequently found in Ontario and Quebec, and has been collected in Manitoba. It is apparently of no importance.

ANTHRACNOSE-Gloeosporium caulivorum Kirch

The only report is from the Central Experimental Farm, Ottawa, where 16 to 60 per cent of the plants in various plots were killed. The seed from which these plants were grown was of European origin.

\section{Mosaic}

In British Columbia, it was serious at Point Grey, causing much trouble in breeding blocks. It was also found in Manitoba, Ontario, and Quebec.

\section{CORN}

Sмuт-Ustilago Zeae (Beck.) Ung.

Reported from all provinces except British Columbia, Alberta, Nova Scotia, and Prince Edward Island. It was common in the provinces in which it was found, being somewhat worst in Ontario and Quebec, infections as high as 4 per cent being reported. 
Rust-Puccinia Sorghi Schw.

Manitoba is the only province from which reports have been received of its occurrence. In 1920 it was not found, but it was severe in 1921, and common but not serious in the other three years.

EAR AND Root Rots-Fusarium spp.

These were reported as present in Manitoba, but not common. In 1922 they were not observed in this province, but Messrs. Bisby and Bailey found the perfect stage of Gibberella Saubinettii (Mont.) Sacc. on old corn stalks in a wheat field.

BaCterial Buight-Bacillus Sorghi Burr.

This was found at Swift Current, Saskatchewan, and St. Vital, Manitoba.

\section{FLAX}

Rust-Melampsora Lini (Schum.) Desm.

Reported from the Prairie Provinces and Ontario. In Alberta, in 1920, it was collected as far north as the Peace River district. The infection was general in these provinces, and though the yield of seed was not lessened, the value of the fibre was undoubtedly impaired. In Manitoba, in 1923, there was a great difference in ${ }^{-}$varietal susceptibility, N.D. 114 having been. injured severely.

\section{WrLT-Fusarium Lini Bolley}

Found in Saskatchewan, Manitoba, and Ontario. In the first two provinces it was not general, but there were fields in which the losses were serious.

At the Central Experimental Farm, Ottawa, it made its first appearance in 1923, causing serious injury to 33 of the one-fortieth-acre plots. The infection progressed during the season along the lines of surface drainage, apparently indicating a spread by water in the soil. In 1924 the plots were again seriously damaged.

Stem BrEak-Polyspora Lini Lafferty

In 1923 it was severe in. two one-fortieth-acre plots at Saskatoon, Saskatchewan. The determination was made by W. E. Brentzel. In 1924, in the same province, it was found again at seven points. The extent of the infection was moderate. Vide Jour. Dept. of Agr. for Ireland, Vol. XXI, No. 2, 1921.

\section{HEAT CANKER}

In Manitoba in 1923 these cankers did considerable injury and were apparently the result of the hot weather in late June and early July. In the same year they were also observed at the Central Experimental Farm, Ottawa, doing considerable damage to the experimental plots.

\section{GRASSES (Cultivated)}

In this section the diseases of the grasses under cultivation only are reviewed. The diseases of the wild grasses will be found in the section dealing with the diseases of miscellaneous plants.

\section{Awnless Brome (Bromus inermis Leyss)}

ERGOT-Claviceps purpurea (Fr.) Tul.

Found in Manitoba in 1923.

Rust-Puccinia Clematidis (DC.) Lag.

Found in Manitoba.

LeAF Spot-Septoria bromigena Sacc.

Has been prevalent in Western Canada for several years. It is an active parasite. 
Kentucky Blue-(Poa pratensis L.)

Ergot-Claviceps purpurea (Fr.) Tul.

Found in Manitoba.

Meadow Fescue (Festuca elatior L.)

Leaf Spot-Helminthosporium dictyoides Drechsler

In plots grown at the Central Experimental Farm, Ottawa, in 1920, from seed imported from Sweden, 90 per cent of the plants were affected with this disease.

Orchard Grass (Dactylis glomerata L.)

ERgot-Claviceps purpurea (Fr.) Tul.

Found in Manitoba.

Rust-Puccinia graminis Pers.

Found in Manitoba:

Perennial Rye (Lolium perenne L.)

ERGOT-Claviceps purpurea (Fr.) Tul.

Found in British Columbia.

Sudan Grass (Holcus Sorghum sudanensis (Piper) Hitchc.)

Piricularia grisea (Cke.) Sacc.

Found in Manitoba.

LEAF SPOT-Pseudomonas sp.

Found in Manitoba.

TALL OAT (Arrhenatherum elatius (L.) Beauv.)

Smut-Ustilago perennans Rostr.

Found in British Columbia.

\section{Тімотну (Phleum pratense L.)}

ErgoT-Claviceps purpurea (Fr.) Tul.

Found in Manitoba.

Rust-Puccinia graminis Phlei-pratensis Eriks. et Henn.

Reported from all provinces except Nova Scotia and New Brunswick. It is occassionally severe but the loss is apparently small.

Leaf Spot-Heterosporium Phlei Gregory.

A small amount found at Winnipeg, Manitoba, in 1923.

LEAF SPOT-Scolecotrichum graminis Fckl.

Some found in southeastern Manitoba in 1923; the damage was slight.

\section{Western Rye (Agropyron tenerum Vas.)}

ERgot-Claviceps purpurea (Fr.) TuI.

Found in Manitoba.

Rust-Puccinia Clematidis (DC.) Lag.

Reported from Saskatchewan and Manitoba.

Rust-Puccinia graminis Pers.

Found in Saskatchewan and Manitoba. 
Rust-Puccinia montanensis E. et E.

One affected plant found in the Craigmyle district, Alberta.

Smut-Ustilago Agropyri Clinton

Reported from the Prairie Provinces. In 1924, one field in Saskatoon, Saskatchewan, had a 10 per cent infection. In that year it was also found at Wadena and Rosthern in the same province.

\section{MILLET}

Suut-Sorosporium Syntherismae (Peck.) Farl.

Collected at Lacombe, Alberta, Saskatoon, Saskatchewan, and Keyes, Manitoba.

\section{- SUNFLOWER}

Rust-Puccinia Helianthi Schw.

Reported from all the western Provinces, Ontario, and Quebec. Every report indicates its general occurrence in these provinces. The injury was not severe, being confined to a defoliation of the lower part of the plants. Some plantations in Manitoba, in 1923, had as high as 100 per cent of the leaves affected.

WiLt or Drop-Sclerotinia sclerotiorum (Lib.) Mass. (=Sclerotinia libertiana Fckl.)

This was the most serious disease of sunflowers. It was reported from every province except Saskatchewan and New Brunswick, and in every province from which it was reported the attacks were serious during one or more years of the five-year period. In 1923 at Brandon, Manitoba, a wind-break was observed with 50 per cent of the plants affected, and one field in Prince Edward Island had 75 per cent of its plants killed. - In 1922, at the Central Experimental Farm, Ottawa, it caused the death of 45 per cent of the plants in a two-acre field. Around Kamloops, and in the Okanagan Valley, British Columbia, in 1923 the losses were considerable.

In 1923 a sample of seed was sent to the Central Laboratory, Ottawa, from Quilchena, British Columbia, containing large numbers of sclerotia, some of these were of the shape which would conform to the spaces between the seeds on the head. Seed contaminated in this way would be difficult to free from the sclerotia, because of their similarity of size and shape to that of the seed. Plants from seed of this kind would have little chance of escaping infection.

Powdery MILDew-Erysiphe Cichoracearum DC.

Reported from Manitoba only. The attacks were local and there was little or no damage.

Downy Mildew-Plasmopara Halstedii (Farl.) Berl. et de Toni

Found to a small extent at Brandon, Manitoba, and Ottawa, Ontario.

Leaf Spot—Septoria Helianthi Ell. et Kell.

Found at Winnipeg, Morden, and Brandon, in Manitoba. In 1924, it did not develop until late in the season.

Gray Mold-Botyrtis sp.

Found attacking the leaves and growing points at Lacombe, Alberta, in 1923 and 1924.

Chlorosis

This was very marked on about 25 per cent of the plants at the Scott Experimental Station, Saskatchewan, in 1923. 


\section{SWEET CLOVER}

Stem Canker-Ascochyta caulicola Law.

It was not found until 1923, when it occurred in the Prairie Provinces. At Olds, Alberta, 6 per cent of the plants were affected and 2 per cent killed. In Saskatchewan it was found at Indian Head and Saskatoon in 1923, and in 1924 at Indian Head it was severe on the yellow sweet clover, while in adjoining plots the infection on the white kind was only slight.

STEM Rot-Botrytis sp.

In the year 1923, near Summerland, British Columbia, one field was found to be dying from this disease.

Leaf Spot-Cercospora Davisii Ell. et Ev. noted.

Found by Dr. Bisby near Dauphin, Manitoba, in 1924. No damage was

Mosaic

This was common at Summerland, British Columbia, and occasionally found in Manitoba, in 1923.

\section{DISEASES OF FRUIT GROPS}

\section{APPLE}

$\mathrm{SCAB}-$ Venturia inaequalis (Cke.) Wint.

This was reported from every province except Saskatchewan and Alberta. It is of such importance that the provinces in which it occurred will be reviewed separately.

British Columbia.-The worst infections occurred during 1920 and 1923. J. W. Eastham states: "It was widespread on Vancouver island and the lower mainland, absent from the dry belt between North Bend and Salmon Arm, including the orchard area at Wallachin, and reappeared at Salmon Arm and along the upper Okanagan valley. At Vernon, where irrigation begins, it is only serious on McIntosh Reds and similarly susceptible varieties, or in a wet season. From Vernon, south, the Okanagan and Similkameen districts are almost free. Occasionally a little appears at Kelowna on McIntosh Reds on the flats, or where air drainage is poor. At Summerland, Naramata, Penticton, and Keremeos, I have never seen the slightest indication of it on fruit or foliage. In the boundary country it occurs on susceptible varieties, but in the Kootenay, Arrow lake section, and Creston valley, it is the worst enemy of the apple, although sprays will generally give 95 per cent control, even on McIntosh Reds. The variety Ontario appears to be the most resistant."

In 1923, in the Kootenays, unsprayed McIntosh Reds showed 100 per cent infection and the sprayed 10 to 25 per cent.

In 1921, 1922, and 1924, the infections were less than usual owing to the prevalence of dry weather. In 1922 unsprayed McIntosh Reds had only 5 to 10 per cent infection.

Manitoba.-It is of common occurrence, but usually not severe enough to warrant spraying.

Ontario.- Unsprayed and poorly sprayed trees suffered severely, particularly in the southern portion. 1924 was perhaps the worst year for scab, particularly on McIntosh Reds. At Vinemount the fruit on some of the trees was worthless and not picked. Severe infections occurred during the year in Essex county.

Quebec.-Complete control is obtained where the orchards are properly sprayed; heavy infections occurred in 1922, where the trees were unsprayed. 
New Brunswick.-It was present throughout the five-year period; spraying reduced the infections, but did not eliminate them. Baldwins showed decided resistance as compared with McIntosh Reds.

Nova Scotia.-Leaf and fruit infections were bad throughout the period, varying with the thoroughness of the spraying and the efficiency of the fungicide employed. Liquid sprays were generally more successful than the dusts in 1924, the infections being more severe in that year than in 1923. At Kentville, Gravensteins and Kings showed 4 per cent on the leaves, one variety, Smokehouse, showed 25 per cent on the fruit. At Telford all varieties showed infection more or less severely, Astrakan having 75 to 100 per cent of the fruit diseased.

Prince Edward Island.--Infections were general during the five years, but not severe, except in 1922 when an average of 26 per cent on the leaves and 58 per cent on the fruit was reported.

\section{Black Rot CANKer-Physalospora Cydoniae Arn.} Scotia.

Reported from Manitoba, Ontario, Quebec, New Brunswick, and Nova

It was by no means as serious as scab. In Manitoba, although present, was not severe and cankers were rare. No severe fruit infections occurred in Ontario; it was not important in the Niagara peninsula. In unpruned orchards in Quebec it apparently followed winter injury; little was observed on the fruits. In New Brunswick it was reported as the most destructive fungus of apple orchards, being especially active in producing cankers; leaf infections were common and materially assisted in early defoliation. It is reported as prevalent in the Annapolis Valley, Nova Scotia, particularly in neglected orchards, causing considerable damage to the leaves and twigs. Leaf infections varied from a trace to 55 per cent, with an average of 9 per cent, and twig infections from 3 to 25 per cent, with an average of 13 per cent.

ANthracnose-Neofabraea malicorticis (Cord.) Jack.

Reported from British Columbia only. In 1920 it was destructive on Vancouver island and the lower mainland, rare in the dry belt, bad at Salmon Arm, absent from the Okanagan, south of Vernon, and from the boundary country, but found slightly at Creston and elsewhere in the Kootenays. Occasionally young trees were killed outright, and sometimes trees in full bearing.

In 1921, as a result of the heavy rains during the previous fall, a serious development of cankers occurred at Vernon in the dry belt. During the remaining years of the five-year period, no new infections occurred, the condition in 1924 being that in unsprayed orchards a great deal occurred on Vancouver island and in the coastal region, further inland only at Salmon Arm, where good control was obtained from spraying.

Powdery MiLdEW-Podosphaera leucotricha (E. et E.) Salm.

Reported from British Columbia only. It was not considered of any importance until 1918, and is still of little importance where climatic conditions render regular spraying for scab a necessity. In the dry belt, however, where scab is almost or quite absent, it was serious when weather conditions favoured the fungus. The loss from this disease is difficult to estimate, for while there is little direct injury to the fruit, there is often a marked stunting of the tree.

SILVER LEAF-Stereum purpureum Pers.

So far it has been reported from British Columbia, Manitoba, Ontario, Quebec, New Brunswick, Nova Scotia, and Prince Edward Island.' The infections in the last six provinces were slight and only isolated cases were found; in British Columbia, however, it is prevalent, as the following reports show:-

"In 1919 and 1920, it was prevalent and caused considerable uneasiness among the fruit growers. During 1921 and 1922 many of the trees infected in previous seasons failed to show symptoms. It was, however, present in practically every orchard, probably not exceeding 1 per cent of the trees."

23056-4 
"In 1923, a silvery sheen on the foliage was present in many orchards. No fruiting bodies of the fungus were found. It is considered that this appearance is due chiefly to a certain type of root injury."-H. R. McLarty.

In 1924, some severe cases were noticed on Northern Spy at East Robson, in which there was not only a general silvering of the leaves, but also a mottling and extensive silvering of the fruit. No fruiting bodies of Stereum or other fungi were found. In the Okanagan, Stereum purpureum was collected in one orchard on trees which had previously suffered from winter injury.

European CANKer-Nectria galligena Bres.

In British Columbia it was present on a few trees in Vancouver, but is of no economic importance. In Nova Scotia it was prevalent in the Annapolis Valley and some other places, causing considerable twig injury. In 1923 it was reported as increasing in the same district and apparently associated with the apple bug.

CANKERS-Nectria spp.

On most of the trees that have suffered from winter injury, this type of canker occurred in British Columbia. In New Brunswick in 1922 cankers on young trees were noted; these may follow winter killing; the fungus associated is usually Nectria cinnabarina (Tode) Fr.

Bitrer Rot-Glomerella cingulata (Stonem.) S. et v.S.

In Quebec two orchards were found with slight infections. In several sections of New Brunswick, in 1922, it caused considerable injury as a bitter rot of the fruit and cankers on the branches. In Nova Scotia, in 1924, considerable pitting, due to this fungus, was found on Gravensteins, after being held in storage for a few weeks.

Collar Rot-Armillaria mellea (Vahl) Quél.

In 1922 it was estimated that thousands of trees were lost every year from this cause in the Okanagan Valley, British Columbia. In 1923 and 1924 it attracted attention again in this province, in some orchards the loss being 15 per cent of the trees. It was considered to be due largely to frost injury; in only a few cases were the rhizomorphs of Armillaria mellea found on the decaying roots.

Fruit Spot-Phoma Pomi Pass.

Reported from New Brunswick and Nova Scotia. In the former province it was prevalent and caused considerable loss in some seasons. In 1919 some orchardists reported 100 per cent of the fruit infected on some trees.

LEAF SPOT-Phyllosticta sp.

One report of this from Quebec. In one orchard it was present to the extent of 100 per cent.

F'LY SPEck-Leptothyrium Pomi (Mont. et Fr.) Sacc.

Reported from Nova Scotia as present, but generally of minor importance.

Sооту BцотсH-Gloeodes pomigena (Schw.) Colby

Found occasionally in Ontario in neglected orchards. Northern Spy seemed to be most susceptible, with infections ranging up to 12 per cent of the fruit.

HEart Rot-Fomes igniarius (L.) Gill. Ontario.

A few cases observed in 1924 in various sections of the Niagara peninsula,

JunIPER Rust-Gymnosporangium Juniperi virginianae Schw. and Gymnosporangium germinale (Schw.) Kern

One or two cases reported from the Niagara peninsula, Ontario; present also in Nova Scotia; not important. 
Brown Rot-Sclerotinia cinerea (Bon.) Schr. (= Sclerotinia fructicola (Wint.) Rehm.) (Sclerotinia americana (Wormald) Norton et Ezekiel).

This has been noted from many sources in Quebec on Yellow Transparent and Montreal apples.

BARK CANKer-Myxosporium corticolum Edg.

Reported as common, but not severe, in the Niagara peninsula, Ontario.

\section{Bacterial Diseases}

Fire Blight-Bacillus amylovorus (Burr.) Trev.

Not reported from Saskatchewan or Alberta.

British Columbia.- "Apparently confined to the Okanagan and Grand Forks districts, Salmon Arm, and the Kootenays. Owing to rigid inspection, better management of irrigation, elimination to a large extent of Transcendent Crabs and Spitzenbergs, the disease has been fairly well under control since 1915."J. W. Eastham (1920).

In 1922 there was an increased amount on the west arm of the Kootenay lake, especially at Harrop, but no new areas were reported. It was again serious in the Salmon Arm and northern Okanagan districts. South of Kelowna it was kept well in hand.

In 1923 it was serious in orchards near affected pear trees, and in 1924 it was not as bad as usual on account of the dry weather at flowering time. severe.

Manitoba.-Apparently general where apples are grown; occasionally

Ontario.-In 1920 the average number of twigs per tree infected in ninetyone orchards in Lincoln county was 1.5 per cent. Since then the disease has spread through the province, it being extremely prevalent and destructive in the Ottawa district during 1923 and 1924 . During these years, in the Niagara peninsula, as high as 70 per cent of the Tolman blossom spurs were destroyed, and about 5 per cent of the twigs destroyed in all varieties. Baldwin and Spy were reported as mark:edly susceptible.

Quebec.-The dar age in this province was evidently not as bad as in Ontario, the reports indicated light infections in a few places, except in 1924, when Transcendent Crabs were reported as badly infected at Macdonald College, and at Centreville a 40 to $: 0$,

Maritime Provin es ---In these three provinces only slight infections were reported.

Crown GaLL-Bacil us 'umefaciens E.F.S. et Town.

In removing fill $r$ irom the Summerland Experimental Station, British Columbia, in 1924, a lat pe percentage was found to be affected. In the same year some cases were rep rted from the Niagara peninsula, Ontario.

Bitter Pit

\section{Non-Parasitic Diseases}

In British Columbia it was severe throughout the Okanagan and Salmon Arm districts, several carloads being ruined by it each year. In 1924 it was more severe than usual, evidently caused by a dry spring followed by heavy irrigation.

In the Niagara peninsula, Ontario, occasional severe attacks have been encountered, principally on Baldwins.

It is reported as of minor importance in Nova Scotia.

Drought Spot

Reported from British Columbia only. Losses were considerable in the Okanagan Valley and the Salmon Arm district, in some orchards as high as 75 $23056-4 \frac{1}{2}$ 
per cent in 1922. In 1923 and 1924 the losses were not as great. Mr. McLarty states: "A point worthy of notice was that it occurred in certain orchards where corky core was bad the previous year."

\section{CORKY Core}

Mr. McLarty describes the trouble as follows: "It is characterized by a few corky spots in the neighbourhood of the vascular ring at the core, and by a somewhat water cored appearance inside this vascular ring. The injury apparently occurs at some time before thinning."

In 1922, in the Salmon Arm district, British Columbia, an exceedingly heavy loss was incurred through this trouble. Fully 25,000 boxes of Wealthies, and from 30 to 40 per cent of the Jonathan and McIntosh were found to be unmarketable.

In 1923, it was practically absent from the Salmon Arm district, but was present in several orchards scattered through the Okanagan valley. The losses sustained were as high as 30 to 40 per cent of the crop, in some instances.

In 1924, in the same districts it occurred in several orchards; the corky tissue appearing more in the flesh of the apples, being not as closely confined to the core as formerly. In the Kootenay district, core browning and similar physiological troubles were particularly severe. In one or two cases the produce of McIntosh orchards was almost worthless.

In 1924, at the Experimental Station at Ste. Anne de la Pocatiere, Quebec, internal browning and the breakdown of flesh around the cores occurred in apples in storage. It was the first year in which it was observed, there being no apparent cause. The weather was favourable, neither drought nor too much rain.

\section{WINTER INJURY}

British Columbia.-Considerable injury occurred in the Salmon Arm and Okanagan districts during the years 1922 to 1924. In 1924 in the northern end of the Okanagan valley, late maturing varieties such as Newtown and Delicious were severely affected, in some instances as many as 90 per cent of the trees were killed. In 1923, the lack of maturity of the wood, caused by heavy rains after a dry summer, resulted in considerable loss from this cause.

- Prince Edward Island.-In orchards near Charlottetown, a considerable amount of injury occurred in some varieties in 1924.

\section{APRICOT}

SILVER LeaF

H. R. McLarty states: "In 1923 a silvered appearance to the foliage occurred in the Naramata district of British Columbia. The cause was considered to be a type of root injury."

\section{WINTER INJURY}

In 1922 considerable damage to the crown and roots occurred in the Okanagan valley and Salmon Arm, British Columbia.

\section{BLACKBERRY}

ORANGE Rust-Gymnoconia interstitialis (Schl.) Lag.

It is reported as the principal disease of this fruit in the Niagara peninsula, Ontario. It is the largest factor against the cultivation of this berry. It is widespread in this area, with infections ranging from 1 to 25 per cent.

In Quebec it was found in Hull county and at Macdonald College.

In New Brunswick it is plentiful on wild blackberries from June 20 to July 15,100 per cent on roadside patches. None was found in the cultivated patches.

In Nova Scotia it was found at Kentville and Hall's Harbour. 
LEAF Spot-Septoria Rubi West.

It is common in the Niagara peninsula, Ontario, but not important.

ANTHRaCNose-Gloeosporium venetum Speg.

Found in Halton county, Ontario.

Crown Gali-Bacillus tumefaciens E.F.S. et Town.

Common in the Niagara peninsula, Ontario; in some patches as high as 60 per cent. In most districts, however, it is not important.

Mosaic

Reported from Macdonald College, Quebec.

\section{CHERRY}

Brown Rot—Sclerotinia cinerea (Bon.) Schr. (=Sclerotinia fructicola (Wint. Rehm.) (Sclerotinia americana (Wormald) Norton et Ezekiel)

British Columbia.-It occurred in the Fraser Valley, where it is often severe, and in the coastal area. There was little on the fruit, but as a blossom blight it was bad, destroying up to 75 per cent of the flowers in some years. On the Saanich peninsula it caused a serious blossom blight on sour cherries in each of the five years, being destructive also on the variety Olivet in the same- district in 1924. The spraying programme recommended for Oregon did not give satisfactory control on Vancouver island. The most susceptible varieties were Black Tartarian, Beauty of Ohio, Empress Eugenie, and Napoleon.

Saskatchewan.-Common on wild choke cherries at Prince Albert and Saskatoon, causing a twig blight.

Manitoba.- Present to a limited extent on sour cherries at Morden.

Ontario.-Blossom blight occurred every year in the Niagara peninsula, some years destroying up to 75 per cent of the blossoms in some orchards. The loss, however, was not serious in years when there was an abundance of bloom. In 1922, sweet cherries rotted badly in transportation.

Nova Scotia.-It occurs generally, being more abundant than usual in 1923.

Prince Edward Island.-Present, the loss from affected fruit averaged 1.5 per cent in 1922 .

SHot Hole or Yellows-Coccomyces hiemalis Higgins

Considerable defoliation occurred in the Niagara peninsula, Ontario, during the months of July and August, particularly on the sweet cherries. 1922 was a good year for the comparison of spraying versus not spraying; where the orchards were sprayed, defoliation was slight, while in those unsprayed, there was 75 to 100 per cent defoliation. Bordeaux mixture gave better control than lime sulphur in 1921.

Infections were fairly general in Nova Scotia, with slight defoliation, and it is present to a limited extent in Prince Edward Island.

Powdery MrLDEw-Podosphaera Oxyacanthae (Fr.) de B.

It occurred in British Columbia, Saskatchewan (on sand cherries), Manitoba, Ontario, and Quebec. It was common, but not severe.

\section{CurI-Exoascus Cerasi Fckl.}

In British Columbia one case was observed in the Penticton district in 1922. Occurred at points in the Fraser valley in 1923, but not in commercial orchards. In the same year one tree was found to be badly injured at Summerland. In the Niagara peninsula, Ontario, it is scarce.

Black KNot-Plowrightia morbosa (Schw.) Sacc.

Reported from British Columbia, Manitoba, Ontario, Quebec, Nova Scotia, and Prince Edward Island. The attacks were slight on cultivated cherries, more common on the wild form. 
Blight-Coryneum Beijerinckii Oud.

Reported from Saskatchewan only. From 1922 to 1924 it was common and destructive to the leaves and fruit of cultivated sand cherries at Saskatoon.

BREAKDOWN

Mr. H. R. McLarty states: "In 1923 cherries from the Okanagan, British Columbia, broke down badly in shipments. Examination of such fruit failed to show the presence of any one fungus. It is considered that the tissues were unusually weak, due to the different climatic conditions that prevailed this season."

WINTER IN.JURY

In 1924, in the Okanagan valley, British Columbia, severe cases were found where the trunks of cherry trees were killed by frost.

\section{CURRANT}

Leaf Spots-Mycosphaerella Grossulariae (Fr.) Lind. and Pseudopeziza Ribis Kleb.

Reported from every province. It was evidently of common occurrence wherever currants are grown. On the whole there was little loss, but occasionally they were responsible for heavy defoliation, drought at the time of the infection sometimes accentuating the damage. The white kinds were apparently more susceptible than the reds or blacks.

Buister Rust-Cronartium ribicola F. de Wald.

Reported from all the provinces except the three Prairie Provinces. Severe attacks occasionally occurred, with some defoliation, but on the whole the infections result in little or no loss. See also under White Pine.

Rust-Puccinia Pringsheimiana Kleb.

Reported from Saskatchewan, Manitoba, Ontario, and Prince Edward Island. It occurred on both wild and cultivated forms. It was of little or no importance.

Powdery Mildew-Sphaerotheca Mors-uvae (Schw.) B. et C.

Reported from all the provinces, Ontario and west. It was severe on the twigs of black kinds in Saskatchewan in 1922 and 1923, and the losses were sometimes great in British Columbia. In Ontario it was of no importance.

ANgular Leaf Spot-Cercospora angulata Wint.

One record of severe spotting on nearly all leaves of plantations in Colchester county, Nova Scotia, in 1924.

Cane Blight-Nectria cinnabarina (Tode) Fr.

Reported from southeastern Manitoba as sometimes found in injured canes.

\section{GOOSEBERRY}

Powdery Mildew-Sphaerotheca Mors-uvae (Schw.) B. et C.

Reported from British Columbia, Saskatchewan, and all the provinces, Ontario and east. The European varieties were most severely affected; in British Columbia these varieties have to be discarded on this account. In this province, at Burnaby, in 1921, the variety Industry was not affected, although the plantations were never dusted. In New Brunswick, patches dusted with sulphur, and others not dusted, showed 5 per cent and 75 per cent infections respectively.

Leaf Spots-Mycosphaerella Grossulariae (Fr.) Lind. and Pseudopeziza Ribis

Kleb.

No reports were received from Alberta or Quebec. It was present in the other provinces, and responsible for some defoliation, but in general was of little or no importance. 
Rust-Puccinia Pringsheimiana Kleb.

Slight infections on the cultivated varieties, and occasionally common on the wild forms, in Saskatchewan, Manitoba, Quebec, New Brunswick, and Nova Scotia.

\section{GRAPE}

BLACK Rot-Guignardia Bidwellii (Ell.) V. et R.

It is reported as common on the wild forms in Quebec. In the Niagara peninsula, Ontario, it is present in poorly kept graperies and those in dead air pockets, but it is well controlled by spraying and is not of economic importance.

Dead ARM-Cryptosporella viticola (Red.) Shear

The only reports are from the Niagara peninsula, Ontario. It was not observed here until 1921. Since then it has become general, and is an important disease, many of the graperies showing 5 per cent infections. As a control measure, heavy pruning was employed successfully.

Powdery Mildew-Uncinula necator (Schw.) Burr.

Reported as present in the Niagara peninsula, Ontario. It was not serious enough to cause any appreciable loss.

Downy Mildew-Plasmopara viticola (B. et C.) Berl. et de Toni.

Occasionally common in Quebec. Present in the Niagara peninsula, Ontario, but unimportant.

\section{PEACH}

LEAF CURL-Exoascus deformans (Berk.) Fckl.

Reported from British Columbia, Ontario, and Nova Scotia. In the first and last named provinces there was some loss in unsprayed orchards, but in the Niagara peninsula it was of greater importance. In this district, in 1920, a long spring gave better opporiunity for thorough spraying, and a count of thirty orchards gave an average of only 5 per cent infection. During the other years the losses were more serious, with occasional serious defoliation and infections ranging from 50 to 100 per cent. Where fall and early spring spraying was practised, good control resulted.

Brown Rot-Sclerotinia cinerea (Bon.) Schr. (= Sclerotinia fructicola (Wint.) Rehm.)

(Sclerotinia americana (Wormald) Norton et Ezekiel).

In British Columbia it did not occur in the principal fruit districts. In the Niagara peninsula it was common, with bad blossom and twig infections occasionally, the variety Mountain Rose being apparently susceptible to ihis type of infection. As a rule this disease is not as serious on peaches as it is on cherries.

ScAB-Cladosporium carppohilum Thüm.

Reported only from the Niagara peninsula, Ontario. In 1922 and 1924 it was of little importance, but in 1921 and 1923 it was troublesome and caused some reduction in the quality of the fruit. The varieties St. John, Elberta, and Smock, were apparently most susceptible.

Powdery MILdEw-Sphaerotheca pannosa (Wal.) Lév.

In British Columbia it used to do much damage, but with the introduction of compulsory spraying with lime sulphur for the Peach Twig Borer, it was much reduced and was of little importance during the period under review.

In the Niagara peninsula, Ontario, it was fairly severe in orchards with poor air drainage, but, on the whole, was unimportant.

Bacterial Blight-Bacterium Pruni E.F.S.

Rather common in the Niagara peninsula, Ontario, but unimportant. 
Crown Gali-Bacillus tumefaciens E.F.S. et Town.

In many sections of the Niagara peninsula, Ontario, where trees were being uprooted, it was found.

\section{Yellows and Little Peach}

Reported only from the Niagara peninsula, Ontario. The system of inspection and eradication carried on by the Ontario government is responsible for the comparative freedom from these diseases during the five years under review.

\section{Drought Spot}

Mr. H. R. McLarty states: "In 1923, in British Columbia, a spotting of the fruit occurred in many orchards. Examination showed the absence of any fungus. The provincial entomologist stated that the injury was not due to any insects. Examination of the root systems showed extensive injury to the fibrous roots."

SCAB-Venturia pyrina Aderh.

\section{PEAR}

In British Columbia, in 1922, the fruit was usually clean, but in 1923 it was bad at the coast. In some orchards, unsprayed Bartletts and Flemish Beauty showed 75 per cent and 100 per cent respectively. In 1924 it was severe on these susceptible varieties only.

It is of general occurrence in the Niagara peninsula, Ontario, but is of no great economic importance. Flemish Beauty was found in Halton county to be susceptible. In the occasional severe cases it is accompanied by cracking of the fruit.

In Nova Scotia and Prince Edward Island it also occurs, particularly on late varieties.

LEAF SPoT-Mycosphaerella sentina (Fr.) Schr.

Present in Ontario and Nova Scotia, but not important.

Powdery MiLdew-Podosphaera leucotricha (E. et E.) Salm.

In the Okanagan valley, British Columbia, it was general in many orchards, in 1924, causing some defoliation of the tips and russetting of the fruit.

LEAF Blight-Fabraea maculata (Lév.) Atk.

Its presence was reported from Rosthern, Saskatchewan, and it occurred in the Niagara peninsula, Ontario; not important.

Fire Blight-Bacillus amylovorus (Burr.) Trev.

In British Columbia, in 1921, it appeared to be under control in most districts, but it appeared at Salmon Arm in epidemic form for the first time, and was also severe in Kelowna and the southern Okanagan. In 1922 it reappeared in the above mentioned districts, but was under control in Penticton and Summerland. In 1923 the infections were, on the whole, more severe than in 1922, it having reappeared in the Creston district after being absent for four years. In 1924 the losses were not as serious as usual.

In Ontario it is common and severe. In some cases the trees were killed.

It was also reported from Quebec and Nova Scotia.

Crown GaLL-Bacillus tumefaciens E.F.S. et Town.

One record of a small orchard in Grantham township, Ontario, where several trees were killed, a large number of galls being found on the roots. This soil had been planted to raspberries previously.

\section{Drought Spot}

H. R. McLarty states: "In 1923 an injury similar to the drought spot of apple occurred in several pear orchards in southern Okanagan. The causes were considered to be the same as those in the apple." 
Core Rot

H. R. McLarty states: "This trouble appears to be of a physiological nature and is characterized by a breaking down of the fruit at the calyx end, and by the formation of an abnormal number of stone cells in the flesh. In the Penticton district one orchard was affected where about 5 per cent of the fruit was lost."

\section{PLUM}

Brown Rot-Sclerotinia cinerea (Bon.) Schr. (= Sclerotinia fructicola (Wint.) Rehm.

(Sclerotinia americana (Wormand) Norton et Ezekiel.

It was reported from every province except Alberta, Saskatchewan, and New Brunswick.

In British Columbia it was of little importance on the whole, although severe infections occurred in the Fraser Valley in 1920, and in the Agassiz and Mission districts in 1923. In the latter districts the variety Grand Duke was found to be somewhat resistant.

In Manitoba it does some damage; the native plums appear to be immune, while the hybrids having Prunus triflora blood are markedly susceptible.

In the Niagara peninsula, Ontario, in every year except 1921 there were losses of 2 to 4 per cent. In 1924 the varietics Bradshaw and Reine Clude were most susceptible.

In Quebec, Nova Scotia, and Prince Edward Island, occasional severe attacks were noted, but on the whole the loss was not great.

Plum Pockets-Exoascus Pruni Fckl.

Reported from Saskatchewan, Manitoba, Ontario, Quebec, Nova Scotia, and Prince Edward Island. It was prevalent especially during the last three years on both wild and cultivated forms.

SHот HoLE-Coccomyces prunophorae Higgins.

Occurred occasionally in Saskatchewan and Manitoba. In the Niagara peninsula, Ontario, it was common in unsprayed orchards, particularly on the Japanese varieties. Serious defoliation was reported from some orchards in Quebec.

BLACK KNoт-Plowrightia morbosa (Schw.) Sacc.

Reported from every province except Alberta and Saskatchewan. It was of common occurrence on wild plums, and in unsprayed and unpruned orchards. In well kept orchards it was of no importance.

ScAB-Cladosporium carpophilum Thüm.

Dr. B. T. Dickson states: "In 1923, at Macdonald College, Quebec, a shot hole disease, caused by this fungus, occurred, the trees being 100 per cent affected. The trees appeared quite brown at a distance, and many branches of some of them were completely defoliated." In 1924 there was only very little of it present on these trees.

In 1923, at Brandon, Manitoba, it was collected on cultivated plums, seriously affecting the appearance of the fruit.

\section{Silver LEAF}

Dr. Bisby, 1920, states: "Seriously affecting a few trees at Winnipeg, Manitoba."

\section{Drought Spot}

Very severe in the northern end of the Okanagan valley, British Columbia, especially in very dry orchards or those suffering from seepage. 


\section{QUINCE}

LeAf Spot—Fabraea maculata (Lév.) Atk.

In the Niagara peninsula, Ontario, it was common and did considerable damage where spraying was neglected. In 1923, severe infection of the black spot or fruit spot stage was reported from the Queenston district, where shipments of fruit showed marked deterioration due to this disease.

RusT-Gymnosporangium germinale (Schw.) Kern.

Present in the Niagara peninsula, Ontario, but of little importance.

\section{RASPBERRY}

Cane Blight—Leptosphaeria Coniothyrium (Fckl.) Sacc.

Reported from Ontario, Quebec, and Nova Scotia. In some plantations it was quite severe, particularly on Herberts.

Blue Stem-Acrostalagmus caulophagus Law.

Occurred in the Niagara peninsula, Ontario, in 1922, on black raspberries. The organism was isolated, and its identity established.

In 1923, Dr. G. H. Berkeley reported in the same district that a cane disease was present in three-quarters of the plantations, with infections as high as 10 per cent. It is not certain what proportions of this were due to Leptosphaeria Coniothyrium (Fckl.) Sacc., and Acrostalagmus caulophagus Law. Internal isolations from five plantations have in most cases given blue stem cultures from red as well a black raspberries. Observations in the field showed that the bulk of this disease may be due to blue stem. In any case this was the first report of the occurrence of blue stem on red raspberries.

In 1924, this disease was common and apparently on the increase, infections running as high as 75 per cent in some plantations, the average being about 10 per cent, it being found in the Niagara peninsula as well as in western Ontario.

Anthracnose-Plectodiscella veneta (Speg.) Burk. (Gloeosporium venetum Speg.)

Reported from British Columbia, Ontario, Quebec, New Brunswick, Nova Scotia, and Prince Edward Island.

With the exception of two reports in 1923 from Macdonald College, Quebec, and the Fredericton Experimental Station, New Brunswick, the damage caused by this disease was small.

Black raspberries and the red variety Herbert, seemed to be the most susceptible.

SPUR Blight-Mycosphaerella rubina (Pk.) Jacz.

Reported to be of common occurrence in Manitoba, Ontario, Quebec, Nova Scotia, and Prince Edward Island.

The injury to the canes was superficial, some of the lateral buds being killed, but the resultant loss was slight.

Powdery Mildew-Sphaerotheca Humuli fuliginea (Schl.) Sal.

One report only, from Manitoba, where it was found to be abundant on Latham and slight on Ohta, with Herberts free.

Leaf Spot-Mycosphaerella Rubi (West.) Roark. (Septoria Rubi West.)

Slight injury reported from Manitoba and Ontario. Herberts were found to be somewhat more susceptible.

Orange Rust-Gymnoconia interstitialis (Schl.) Lag. Scotia.

Slight infections reported from British Columbia, Ontario, and Nova 
Yellow Rust-Phragmidium imitans Arth.

Described in the North American Flora, Vol. 7, Part 3, page 165.

In 1919 it caused some alarm in the Fraser Valley, British Columbia, but in subsequent years it proved to be of little importance.

Crown Gall-Bacillus tumefaciens E.F.S. et Town.

Found in British Columbia, Ontario, and Prince Edward Island. It was of little or no importance.

Mosaic

Alberta was the only province from which this disease was not reported.

British Columbia.--In 1922 it was noticed in the Burnaby district, near the mouth of the Fraser river. In 1923 a severe case was found at Nelson, and it occurred at Salmon Arm and in the Fraser and Okanagan valleys. In 1924 it was general in the Okanagan.

Saskatchewan.-In 1924 a small garden at Rosthern showed a noticeable amount.

Manitoba.-In 1920 it was found affecting a considerable percentage of plants, since then it has become widely distributed.

Ontario.- It has been epiphytotic in this province during the whole period under review. It was of great importance and caused large losses wherever susceptible varieties were grown. In 1922, a survey of its occurrence showed a considerable spread. The system of inspection and certification of nursery stock commenced by the Division of Botany in this year, showed results in 1923 and 1924 , in that the disease, although still bad, had not spread to nearly the same extent as it did in 1922.

In Quebec, New Brunswick, Nova Scotia, and Prince Edward Island, it is common on the susceptible varieties, infections ranging from 10 to 90 per cent were reported in various plantations. In Prince Edward Island the gradual spread during the years 1922 to 1924 was marked.

LEAF CURL

Reported from all the provinces, Manitoba and eastward.

Like mosaic, it is of great importance, although the percentage of affected. plants was not as high as those affected with mosaic. The inspection and. certification of nursery stock is helping to eradicate this disease also.

Varietal susceptibility and resistance was practically the same as that recorded for mosaic, with the addition of King and Newman No. 24 to those showing some resistance to leaf curl.

WINTER INJURY

Injury of this type was prevalent in many localities in Ontario during the years 1922 to 1924 , particularly in plantations three years old and older.

\section{STRAWBERRY}

LeAF Spot—Mycosphaerella Fragariae (Schw.) Lin.

Reported from all the provinces of the Dominion, and apparently present in almost all plantations, but with only small resultant loss, except where the plantations are maintained for more than two years. In British Columbia, where in many sections the practice of short rotations, and cutting and burning of the foliage is necessary for the control of the root weevil, this disease is of no importance.

At the Central Experimental Farm, Ottawa, where a large number of varieties are grown, the following have shown marked resistance: Portia, Pokamoke, Parson's Beauty, and Lavinia.

Mr. A. Kelsall states: "In Annapolis county, Nova Scotia, in 1923, the areas dusted or sprayed with Bordeaux mixture for the control of the weevil, contained much less leaf spot than the patches not so treated. Where sulphur compounds were used, control was noted, but not to the same extent as with the Bordeaux." 
LeAF Scorch.-Mollisia earliana (E. et E.) Sacc.

Reported from Ontario and the three Maritime Provinces. In the latter provinces, slight, localized infections were reported. In Ontario, in 1921 and 1922 , it was regarded as the most serious disease of strawberries, early infections of petioles and laminae causing serious defoliation, with its consequent result on the quality and quantity of fruit. Many patches showed 100 per cent infection. In 1923 and 1924, however, only a few cases were noticed, and it was far less important.

Powdery Mildew-Sphaerotheca Humuli (DC.) Burr.

Reported from Saskatchewan, Ontario, and the three Maritime Provinces. ance.

Occasional severe attacks were noted, but on the whole it is of minor import-

In New Brunswick, the varieties President, Beans, American, Sample, and Parson's Beauty, showed marked susceptibility; and Portia, Viola, and Splendid, considerable resistance.

Fruit Rots-Botrytis and Rhizopus spp.

Found in Manitoba, Ontario, New Brunswick, and Nova Scotia. Plants with dense foliage from heavy fertilization or other causes, had a considerable number of their fruits rotted.

BLACK RoOT

Caused by frost injury. Found in some localities in Ontario where in the majority of seasons some injury of this type occurs if the plants are not covered with straw after the ground first freezes.

Root Rot

The definite cause of this is so far undetermined, although it is thought to be of bacterial origin. It was reported from Ontario, Quebec, New Brunswick, and Prince Edward Island. In isolated cases it was responsible for the death of 20 per cent of the plants.

\section{DISEASES OF VEGETABLE AND FIELD CROPS}

\section{ASPARAGUS}

Rust-Puccinia Asparagi D.C.

It was found late in the season in Manitoba, Ontario, and Quebec. The injury to the plants was slight, if any. In British Columbia it was looked for, but could not be found. No doubt it occurred in the other eastern provinces, but was not reported.

Rusty Tips

A rusty browning of unknown cause was found on the marketable tips in gardens and on the stock offered for sale in British Columbia, Ontario, Quebec, and New Brunswick. There was no indication of reduction in yield, but many of the tips were unmarketable.

\section{BEAN}

Anthracnose-Colletotrichum Lindemuthianum (Sacc. et Magn.) Br. et Cav.

The most important bean disease. It occurred in every province.

In the provinces from Manitoba west severe local infections were noted, the worst being at Brandon, Manitoba, in 1923, when all varieties, except Canadian Wonder, had infections up to 100 per cent.

In Ontario and Quebec it was common and destructive, particularly in 1922, when weather conditions were ideal for its development and spread. In Quebec, the varieties Hodson Long Pod, Stringless Green Pod, and Refugee, showed some resistance. 
In New Brunswick it was common and of great importance on bush beans, being rarely found on pole beans. On the whole the losses here were worse than in Ontario and Quebec.

In Nova Scotia and Prince Edward Island it was prevalent, and serious losses occurred in certain localities.

Stem Rot oR Wilt-Sclerotinia sclerotiorum (Lib.) Mass. (=Sclerotinia libertiana Fckl.)

Reported from Ontario, Quebec, New Brunswick, and Nova Scotia. In New Brunswick in some sections, in 1922, the crop was completely destroyed.

At Ste. Anne de la Pocatière, Quebec, in 1924, practically every plant in the fields at the Agricultural College was affected, stems, leaves, pods, and the surface of the ground having sclerotia and mycelium.

Rust-Uromyces appendiculatus (Pers.) Lév.

Reported from the three Maritime Provinces. Apparently more abundant on pole than on bush beans. In New Brunswick, when a bad attack occurred, it was more destructive than anthracnose.

Pod SpoT-Phyllosticta phaseolina Sacc.

This was reported for the first time in Canada by Mr. K. A. Harrison as follows: "It was found on wax podded, black kidney beans in Central Florence, Annapolis county, Nova Scotia, in 1924. It affected the stem, leaves, flowers, flower buds and pods. The greatest loss was sustained through the destruction of the flowers."

Stem Rot—Rhizoctonia sp.

In 1923, at Raymond and Vauxhall, Alberta, it was found affecting many fields with a loss as high as 10 per cent.

Rоoт Rot-Fusarium sp.

Reported from Manitoba and New Brunswick in 1920, causing losses which did not exceed 2 per cent.

Bacterial Blight.-Bacterium Phaseoli E.F.S.

Reported from every province except British Columbia. In the three Prairie Provinces it was widespread, and especially severe in 1921. The irrigated districts of Lethbridge, Vauxhall, and Brooks in Alberta, suffered badly in 1923.

In the remaining provinces severe, localized infections occurred, but on the whole it was not responsible for as much loss as anthracnose.

Mosaic

Reported from Manitoba, Ontario, Quebec, New Brunswick, and Prince Edward Island.

It was common, with infections ranging from 2 to 10 per cent. In New Brunswick, seed is obtained from Ontario, and the amount of mosaic present depends on its prevalence in Ontario the previous year. There was not much spread observed in this province.

\section{BEET}

LEAF Spot-Cercospora beticola Sacc.

Reported from all the provinces, Manitoba eastward. It was evidently common, but no serious injury has been reported since 1918, when in southern Ontario several fields showed many of the older leaves dead and badly infected with some injury to the crop.

Rot and Leaf Spot-Phoma Betae Frank

In British Columbia, in 1923, it did some damage at Duncans and Lulu Island, the causal fungus being identified by isolation. The only other report is from Manitoba, in 1924, considerable loss in storage occurring at St. Vital. 
Rоoт Rot-Rhizoctonia sp.

Reported from Ontario and New Brunswick, where occasional localized infections occurred.

$\mathrm{ScAB}-$ Actinomyces scabies (Thax.) Güssow

Isolated cases were reported from Ontario, Quebec, and New Brunswick. It was of little or no importance.

\section{CABBAGE}

Club Root-Plasmodiophora Brassicae Wor.

Reported from British Columbia and all the provinces Ontario eastward. It was worst in Nova Scotia, the losses being on the whole slight in the other provinces.

RoT—Sclerotinia sclerotiorum (Lib.) Mass. (= Sclerotinia libertiana Fckl.)

One report only, from Ste. Anne de la Pocatiere, Quebec, in 1924, where it was found in a field in which the fungus had been present on beans, radishes, and cucumbers, four years before. The attack was not severe.

LeaF Spot-Alternaria Brassicae (Berk.) Sacc.

One report only, from the Niagara peninsula, Ontario, where this disease occurred to a slight extent in 1924.

BLAck Rot—Bacterium campestre (Pammel) E.F.S. Island.

Reported from British Columbia, Ontario, Quebec, and Prince Edward

In a few instances it was serious and caused some loss, but on the whole it was not important.

SoFT Rot-Bacillus carotovorus Jones.

In 1923, in British Columbia, after a wet period in July, it occurred in all patches from Kelowna south, severely damaging the outer leaves; the dry weather following, however, checked its spread.

In 1923, in Manitoba, there was a moderate amount of damage.

At Fredericton, New Brunswick, in 1924, there was a slight primary injury. This, however, spread rapidly when the cabbages were piled awaiting shipment.

\section{CANTALOUPE}

LeAF Spot-Alternaria Brassicae (Berk.) Sacc.

In 1923 it caused considerable damage to two or three patches in the Niagara peninsula, Ontario.

Downy Mildew-Peronoplasmopara cubensis (B. et C.) Clint.

It did some damage to frame-grown plants at Morden, Manitoba, in 1923. WiLT-Bacillus tracheiphilus E.F.S.

In 1920, in southern and eastern Ontario, it was serious in many fields, with losses ranging from 5 to 25 per cent.

In 1923 , it affected about 2 per cent of the plants at the Experimental Station, Morden, Manitoba.

\section{CARROT}

Rot-Sclerotinia sclerotiorum (Lib.) Mass. (=Sclerotinia libertiana Fckl.)

In 1920 and 1921 it was found in New Brunswick. It caused a yellowing and browning of the top, a browning of the crown, and a storage rot. The fungus was isolated from the diseased material.

Storage Rot-Rhizoctonia sp.

G. C. Cunningham states: "In 1922 this fungus frequently caused a storage rot of carrots. It was not found in the field, but infection undoubtedly took place before or at the time of harvesting. It was not important. 


\section{CAULIFLOWER}

Club Root-Plasmodiophora Brassicae Wor.

In 1922 specimens of this disease were sent from Outremont, Quebec. No report was given as to the extent of the infection.

BLACK RoT-Bacterium campestre (Pammel) E.F.S.

Reported from Quebec in 1924.

SoFt Rot-Bacillus carotovorous Jones

One report from Manitoba in 1923. It was causing moderate damage.

\section{CELERY}

Late Blight-Septoria Petroselini Desm. var Apii Br. et Cav.

Reported from all the provinces, Ontario eastward. It was found fairly generally, with severe cases occasionally. In 1922, in Ontario, some damage was reported in storage beds. Paris Golden was evidently markedly susceptible, and Golden Self Blanching somewhat resistant.

Early Blight-Cercospora Apii Fr.

Reported from British Columbia, Ontario, Quebec, and New Brunswick. It was not common or ordinarily destructive, but one or two severe outbreaks were noted.

Yellows-Fusarium sp.

One case reported from London, Ontario.

SoFт Rot-Bacillus carotovorous Jones

In British Columbia and Manitoba it caused some damage in 1923. In New Brunswick it occasionally became troublesome late in the season.

\section{CUCUMBER}

Anthracnose-Colletotrichum lagenarium (Pass.) E. et H.

Reported from New Brunswick and Nova Scotia. In the former, in 1920 several fields were severely attacked and caused heavy loss; in 1921 and 1922 it was present but not severe. In the latter, a bad attack occurred at Hantsport in 1924 , the farmer estimating his loss at $\$ 500$.

Sтем Rot-Sclerotinia sclerotiorum (Lib.) Mass. (=Sclerotinia libertiana Fckl.)

One report only from Charlottetown, Prince Edward Island, in 1924, where there were several cases. It spread rapidly and destroyed the patches in a few days.

ScAB-Cladosporium cucumerinum Ell. et Arth.

Up to 1924, it was only reported from St. Vital, Manitoba.

WiLT-Fusarium sp.

In 1923, it was noted in Manitoba. In Ontario, it was found in the Niagara peninsula, in 1924, and in 1920, at Temagami Station, the crop was a total loss from this cause.

WILT-Bacterium tracheiphilus E.F.S.

Reported as fairly common in Ontario, Quebec, and New Brunswick. In Essex county, Ontario, in 1923 and 1924, it caused up to 20 per cent loss in some greenhouses.

ANGUlar LeaF Spot-Bacterium lachrymans E.F.S. et Bryan.

Reported only from St. Vital, Manitoba.

Mosaic

Found in Manitoba, Ontario, Quebec, New Brunswick, and Prince Edward Island. The outstanding attack was in the Niagara peninsula, in 1924, where in one small greenhouse and several garden patches the crop was a complete failure. 


\section{HORSE RADISH}

Leaf Spot-Cercospora Armoraciae Sacc.

One garden badly diseased at Lacombe, Alberta, in 1923.

Leaf Spot—Ramularia Armoraciae Fckl. 1924.

Caused a very conspicuous leaf spotting at Valley River, Manitoba, in

\section{LETTUCE}

Drop-Sclerotinia sclerotiorum (Lib.) Mass. (= Sclerotinia libertiana Fckl.)

Reported from Manitoba, New Brunswick, and Prince Edward Island. The infections were generally slight, with the exception of two fields in Prince Edward Island in 1923, where 75 per cent infections were noted.

In New Brunswick it almost invariably developed on plants left in the field until the flower stalk formed.

Downy MiLdew-Bremia Lactucae Regel.

Reported only from Ontario, where it caused trouble in a few fields and greenhouses.

Gray Mold-Botrytis cinerea Pers.

At St. Vital, Manitoba, in 1924, considerable occurred, causing injury to head lettuce. First found on July 24.

Anthracnose-Marssonia Panattoniana (Berl.) Magnus.

In Ontario it was chiefly a disease of greenhouse lettuce, but is sometimes injurious to plants grown out of doors.

Rust-Puccinia hieraciata (Schw.) Jackson.

At St. Vital, Manitoba, in 1924, the aecia were quite common, but the damage was slight.

Sоғт Rот-Bacterium viridilividum Brown

One report of a 20 per cent loss in Essex county, Ontario, in a patch containing about 600 heads.

TIP BURN

In 1924, it was severe on head lettuce in the Okanagan Valley, British Columbia. It is a limiting factor in the commercial production of the crop throughout this area.-(H. R. McLarty).

\section{MANGEL}

Rоoт Rot-Phoma Betae (Oud.) Frank

In the Okanagan Valley and Vancouver island, British Columbia, it occurred in districts where mangels are grown for seed. It caused a leaf spot and crown injury. There was also a considerable amount found at St. Vital, Manitoba, in 1924.

Crown Gall-Bacillus tumefaciens E.F.S. et Town.

A specimen of this was sent from Apohaqui, New Brunswick, in 1923.

Soft Rot-Bacillus carotovorus Jones

In 1923, it caused considerable damage in the Summerland district, British Columbia.

\section{Root Blight}

J. W. Eastham states: "In 1923, a disease of seedling mangels was observed on Lulu Island, British Columbia. It was apparently identical with that described by Sorauer under the name of 'root blight' (Eng. Ed. pages 226 et seq). It is noteworthy that it was most marked when, owing to weather and labour conditions the soil had been allowed to bake or form a hard crust around the plants." 
Smut-Urocystis Cepulae Frost

\section{ONION}

Reported from Manitoba, Ontario, and Quebec.

In Manitoba it was fisst found in 1922 in a garden near Winnipeg; in 1924 a trace appeared in a field nearby. The growers state that it has been present in a small quantity for five or six years. It was of slight importance.

In Ontario, it was first reported in 1920 from Essex county. In Mersea and Leamington townships of Essex county it was again reported in 1924 as a serious disease.

The worst infestation of this disease occurred in Quebec, on the island of Montreal. In 1922 and 1923 it was so bad that some fields had to be ploughed up. In 1924 it was not as bad as formerly near Montreal, but it was common in fields in Rosemount and in Dorchester County.

Downy Mildew-Peronospora Schleideni Ung. in 1923

In British Columbia it was reported from Chilliwack in 1920 and Agassiz

In Ontario it was common and occasionally caused serious loss.

In Quebec and Prince Edward Island it occurred in a few areas.

Neck Rot-Botrytis Alii Munn

In British Columbia, in 1924, it was common in the Okanagan Valley, where storage conditions were unfavourable, and in storage where improper ventilation prevailed.

It was present in stored onions at Saskatoon, Saskatchewan, in 1922, and a serious infestation occurred in one case at Winnipeg, Manitoba, in 1924.

Pink Root-Fusarium Malli Taub.

Present and serious in Quebec in 1922.

PEA

Leaf and Pod Spots-Mycosphaerella pinnodes (Berk. et Blox.) Stone

Reported from Alberta, Saskatchewan, Manitoba, Ontario, and Nova Scotia. It was not responsible for any serious losses, moderate infections with slight losses being noted.

Blight—Septoria Pisi West.

Found in Alberta, Saskatchewan, Manitoba, Ontario, and Prince Edward Island. The only serious infection reported was at the Central Experimental Farm in 1924, where there was a 100 per cent infection of all plots. The plants ripened prematurely, but no noticeable reduction in yield was observed.

Root Rot-Fusarium and Pythium spp.

In Ontario this disease was of extreme importance, as is shown by the following reports:-

1922- "Out of 3,000 acres in the Wellington district of Prince Edward county, about 14 per cent loss was sustained, an estimated loss of $\$ 12,000$." (J. F. Hockey).

"In certain parts of the province, especially in Prince Edward county, there has been a great deal of trouble with wilt and blight of canning peas. This trouble is probably due to a Fusarium, at least in part, the exact species I am not prepared to state. It is present to some extent in other canning regions, but not quite as bad as in Prince Edward county."-(R. E. Stone.)

1923- "This disease is reported from Prince Edward and Hasting counties again this year. The amount of infection is not quite as extensive as it was last year, as more care was taken in selecting fields which had either not grown peas recently or had not shown any previous symptoms of the trouble."-(R. E. Stone.) 
The variety Little Marble was reported as susceptible, while Horsfood Improved and Telephone were somewhat resistant.

Powdery Mildew-Erysiphe Polygoni D.C.

Reported from all provinces except Nova Scotia and New Brunswick. The infection was general in these provinces, but not serious.

Anthracnose-Colletotrichum Pisi Pat.

Mr. I. L. Conners states: "In 1923, in southwestern Manitoba, it was epidemic, causing premature dying with considerable reduction in yield. This disease has been reported from Wisconsin only."

In 1924 it was slight at Brandon, Manitoba, and Dr. Dearness reported its presence in Ontario.

Rust-Uromyces Pisi (Pers.) Wint.

The only report is from Manitoba, where there was a moderate infection late in the season in 1923.

Leaf Spot-Septoria flagellifera $\mathrm{E}$. et $\mathrm{E}$. 1924.

Small amounts of this were found at Brandon and Winnipeg, Manitoba, in

Bacterial Blight-Bacterium Pisi Sack.

Some leaf spotting noted at St. Vital, Manitoba, in 1924.

Mosaic

Reported from Ontario and Quebec. At Macdonald College, Quebec, the varieties Golden Vine, Canadian Beauty, Prussian Blue, and Chancellor were markedly susceptible.

\section{PEPPER}

Rот-Alternaria sp. 1921.

Occurred at Winnipeg, Manitoba, causing considerable loss, in 1920 and

Blossom End Rot

In British Columbia, in 1922, it caused considerable damage wherever peppers were grown; in one case the loss was 45 per cent of the crop.

It also occurred in Manitoba, where it was common, and in some varieties serious, in 1923.

\section{POTATO}

The importance of the potato crop in the Dominion of Canada, and the relative importance in the various provinces, can be seen from the figures on acreage, yield, and value, given in the following table:-

\begin{tabular}{|c|c|c|c|}
\hline Provinces & $\begin{array}{c}\text { Area } \\
\text { Average } \\
\text { 1918-23 }\end{array}$ & $\begin{array}{l}\text { Yield } \\
\text { Average } \\
1918-23\end{array}$ & $\begin{array}{l}\text { Value } \\
\text { Average } \\
1918-23\end{array}$ \\
\hline & Acres & Cwt. & Dollars \\
\hline 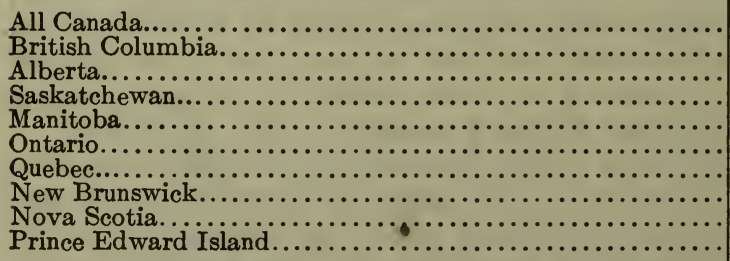 & $\begin{array}{r}652,871 \\
17,719 \\
42,677 \\
53,082 \\
34,350 \\
164,136 \\
210,855 \\
58,847 \\
37,845 \\
33,357\end{array}$ & $\begin{array}{r}61,588,940 \\
2,021,522 \\
4,257,096 \\
4,701,554 \\
2,716,342 \\
11,393,562 \\
22,475,080 \\
6,852,606 \\
4,208,500 \\
2,953,678\end{array}$ & $\begin{array}{r}76,538,940 \\
2,839,030 \\
3,805,970 \\
5,180,390 \\
2,698,330 \\
16,755,220 \\
28,757,600 \\
8,130,480 \\
5,968,400 \\
2,413,520\end{array}$ \\
\hline
\end{tabular}


The survey of potato diseases for the five years, 1920 to 1924, here dealt with, is based largely on information obtained through the inspection and certification service carried on in all the provinces by the Division of Botany, Dominion Department of Agriculture. The following tables show the extent of the work performed by this service and the inspection standards for certified seed:-

POTATO INSPECTION AND CERTIFICATION IN ALL PROVINCES OF CANADA EXCEPT BRITISH COLUMBIA

\begin{tabular}{|c|c|c|c|}
\hline Year & $\begin{array}{c}\text { Acres } \\
\text { inspected }\end{array}$ & $\begin{array}{c}\text { Acres } \\
\text { certified }\end{array}$ & $\begin{array}{l}\text { Bushels } \\
\text { certified }\end{array}$ \\
\hline $\begin{array}{l}1920 \ldots \ldots \ldots \ldots \ldots \ldots \\
1921 \ldots \ldots \ldots \ldots \ldots \ldots \ldots \\
1922 \ldots \ldots \ldots \ldots \ldots \ldots \ldots \\
1923 \ldots \ldots \ldots \ldots \ldots \ldots\end{array}$ & $\begin{array}{r}7,613 \\
7,900 \\
11,250 \\
9,681 \\
18,942\end{array}$ & $\begin{array}{r}3,956 \\
4,290 \\
6,991 \\
7,100 \\
13,716\end{array}$ & $\begin{array}{r}333,517 \\
469,658 \\
525,000 \\
735,298 \\
1,275,000\end{array}$ \\
\hline
\end{tabular}

British Columbia did not come under the Dominion administration of this service until 1924, when 296 acres were inspected, and 219 certified.

INSPECTION STANDARDS FOR CERTIFIED SEED, 1925

FIELD

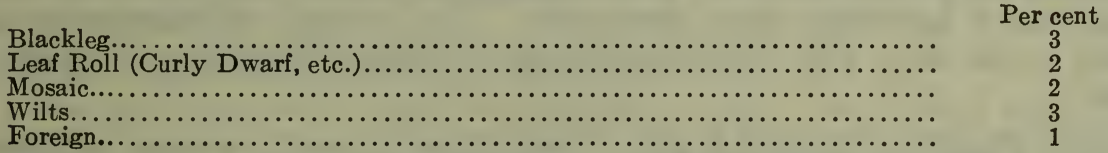

Providing that in no case shall a total of more than 6 per cent be allowed.

TUBER

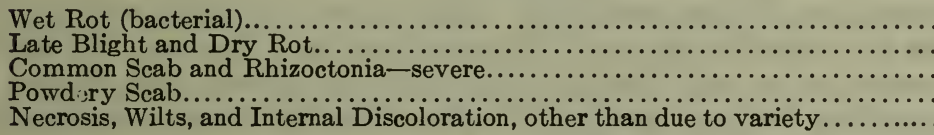

Per cent
2
3
5
1
5

Providing that in no case shall a total of more than 10 per cent be allowed.

Not more than 2 per cent of the tubers shall be foreign, badly off type, or damaged by sunburn, cuts, cracks, bruises, insects, etc.

No frost injury shall be allowed.

Not more than 5 per cent by weight of the tubers shall be below three ounces or above twelve ounces.

Late Blight-Phytophthora infestans (Mont.) De Bary

On account of dry atmospheric conditions in the Prairie Provinces, it is rarely present, the only specimens collected and reported in the five years were in 1922, when trace infections were found.

In British Columbia, it was occasionally found in the Lower Fraser Valley, also in the Chilliwack and Delta areas, and on Vancouver island. On the mainland it was not found east of Agassiz and Chilliwack. In the districts mentioned some severe losses were sustained in 1921 and 1922 . In these cases the attack was late, but it resulted in considerable tuber infection, in several cases as high as 50 per cent.

In Ontario and Quebec the infections were moderate during the first four years, but much worse in 1924 . In this year a late infection, coupled with wet weather at digging time, caused considerable loss in storage, out of all proportion to the amount of leaf infection. 
In the Maritime Provinces the amount of infection with the resultant losses were far greater than in any other part of the Dominion. P. A. Murphy made the following estimate of the percentage of the possible crop which was lost from this cause and the corresponding loss in bushels, during the years 1915 to $1919:-$

\begin{tabular}{|c|c|c|}
\hline Province & $\begin{array}{l}\text { Per cent of } \\
\text { possible } \\
\text { crop lost }\end{array}$ & Bushels \\
\hline 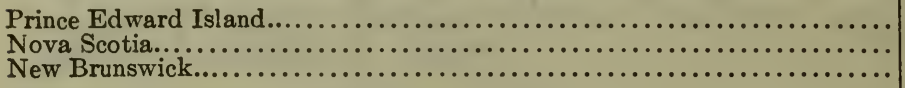 & $\begin{array}{l}43 \\
30 \\
25\end{array}$ & $\begin{array}{l}3,900,000 \\
2,800,000 \\
2,833,000\end{array}$ \\
\hline
\end{tabular}

During the period under review, the reports indicate that while the losses were serious they were not as high as those during the previous five years, as estimated above.

The only mention of varietal resistance in the reports, points out the greater susceptibility of Green Mountain as compared with Irish Cobbler.

EARLy Blight-Alternaria Solani (E. et M.) J. et G.

Reported from every province, with occasional loss from defoliation and premature ripening of the leaves. There was, on the whole, no marked difference between the provinces in the extent of its occurrence, and in no one or more years was it uniformly more destructive. The average of infections would be below 1 per cent, with exceptional cases of higher infection and considerable loss.

Wilts-Fusarium oxysporum Schl. Verticillium albo-atrum Reinke et Berth.

These two diseases are dealt with jointly, for most of our reports cover the wilt diseases without differentiation between the two kinds. There is no doubt that the former is the more prevalent.

They occurred in all the provinces. The worst infection was in British Columbia, where it is regarded as one of the serious potato diseases. In Manitoba the organisms seem to be well distributed in the soils there, the disease being of common occurrence but not serious. In the other provinces a small amount occurred every year, but was not serious.

Rhizoctonia-Corticium vagum B. et C.

Reported from every province, but it was far more prevalent in Manitoba than in any of the others. It was one of the most troublesome diseases in this province and no sections are known to be free from it. It was responsible for many misses in the field; stem lesions, tuber sclerotia, and the perfect stage being abundant. Experiments with early digging have demonstrated its advantage as a means of reducing the number of sclerotia on the tubers; 1 to 5 per cent affected tubers on September 1, were found to increase to 70 to 75 per cent by October 20.

In the other provinces it was common and of varying severity, but not a prominent factor in the reduction of yield.

\section{Silver ScurF-Spondylocladium atrovirens Harz}

It was reported from every province except Nova Scotia; it was fairly common, but of little or no economic importance.

Drop-Sclerotinia sclerotiorum (Lib.) Mass. (=Sclerotinia libertiana Fckl.)

It was reported from Quebec, New Brunswick, and Prince Edward Island. The only report of loss from this cause was in Restigouche county, New Brunswick, in 1922, where a premature wilting resulted from the attack of this fungus. 
Gray Mold-Botrytis cinerea Pers.

One report from New Brunswick in 1922, where in a number of fields premature death of plants was associated with the presence of this fungus.

DRY RoT-Fusarium oxysporum Schl.

A fairly common storage rot wherever potatoes were grown occurred frequently in tubers with mechanical injuries. Considerable loss from this cause was reported from Manitoba in 1921.

BLAcK Doт-Colletotrichum tabificum (Hallier p.p.) Pethybridge

Quebec is the only province from which it was reported, but it is no doubt present in other provinces. In 1922 and 1923, bad attacks were noted in Quebec, it being of frequent occurrence during the latter part of the seasons. In some fields as high as 5 per cent was reported. The amount of injury depends upon what stage in the development of the plants the stolons are attacked.

ARMILlaria Rot-Armillaria mellea (Vahl.) Quél.

In northern Manitoba in 1921, in a crop grown on new land, several tubers were found bearing strands similar to those illustrated in Bisby and Tolaas' bulletin "Potato Diseases in Minnesota."

Powdery SCAB-Spongospora subterranea (Wallr.) Johns.

Reported from every province except Saskatchewan and Manitoba. During the five years under review no serious spread has been observed, and so far it has not been responsible for any appreciable loss. It was not nearly as prevalent as the common scab.

Skin Spoт-Oospora pustulans Owen et Wakf.

A few specimens were found in Manitoba in 1921. In 1923, it was found, for the first time, in Prince Edward Island, where in stored potatoes slight to severe infections were found on some tubers of McIntyre, Irish Cobbler, and Green Mountain.

ScAB-Actinomyces scabies (Thax.) Güssow

It was found in every province and is generally prevalent; in some fields the crop showed 100 per cent infection. Considering the general prevalence of this disease and the number of severe infections, the resultant loss was not great, the greatest money loss being in the failure to obtain certification in otherwise sound stock.

All varieties were apparently equally susceptible. The soil alkalinity produced by the applications of mussel mud in Prince Edward Island, and the dry seasons in the Prairie Provinces, appeared to be factors in increased infections. So far, in Canada, there has been no reported control obtained from the use of sulphur.

BLACK LEG-Bacillus solanisaprus Har.

It was found in every province. The usual infection reported varies from a fraction of 1 per cent up to 2 per cent, with occasionally 4 per cent. The most serious infections occurred in 1922, when in the three Prairie Provinces 443 acres were rejected for certification on this account. In the Maritime Provinces also it was more abundant than usual, and caused considerable loss. In 1924, in Nova Scotia, differences from a trace infection to 5 per cent were observed between fields where seed treatment and rogueing had been employed as compared with those in which no control measures had been adopted.

\section{Mosaic}

Found in every province and the cause of much loss every year. While the average percentage of infection in fields offered for certification is only about. 4 per cent, this figure does not represent the actual percentage in the crop as a. whole, for the information is obtained largely from fields which are grown from. 
the best seed, in order to have them qualify for certification. It is frequent to have reports of infections as high as 50 per cent, and occasionally 100 per cent. Estimates on the reduction of yield would be at the best a guess, but if the basis for computing losses in relation to percentage of infection used in the United States was applicable to conditions in Canada, it would indicate an average loss from this cause of at least 8 per cent annually in the Dominion as a whole.

The varieties Green Mountain, McIntyre, Sir Walter Raleigh, Mill's Pride, Garnet Chili, Bliss Triumph, and White Rose apparently showed decided susceptibility, while King Edward, Edzell Blue, Barnhouse Beauty, Majestic, and King George, exhibited some resistance in some localities.

\section{LEAF ROLL}

It was reported from all provinces. The percentage of infections and the probable reduction in yield of crop, although fairly high, are not as high as the figures computed for mosaic, being about 6 per cent. This is computed on the basis of a 30 per cent infection causing a 20 per cent reduction in yield, as used in the United States.

The Irish Cobbler showed marked susceptibility to this disease, and Green Mountain considerable resistance.

CUrLy DwarF

It was found occasionally in all the provinces west of, and including, Quebec. It was of little importance and not a decided factor in the reduction of yields.

\section{STREAK}

There was only one report, which states that it was found on a few plants of Spaulding Rose and Beauty of Hebron in New Brunswick.

SPINDLING TUBER

In New Brunswick, during the years 1919 to 1923 , a trouble resulting in low yields, long pointed tubers, with a large number of deep eyes, similar to the description given by Shultz and Folsom in J.A.R. 25:2, was found. It was chiefly noticeable in Irish Cobblers and Spaulding Rose. Only three strains of Irish Cobbler are known to show less than 5 per cent, and many fields showed from 25 to 50 per cent. The Green Mountains were, apparently, quite free from the trouble.

An effort is being made in New Brunswick to get rid of the susceptible strains by selling them for table stock. This disease is of major importance to seed buyers in the United States, hence the necessity of eliminating the diseased stock.

\section{WrTches' Broom}

This was found at Summerland, British Columbia, and in the Rainy River district, Ontario, in 1924.

\section{Net Necrosis}

Small percentages were reported from all the provinces except British Columbia, Nova Scotia, and Prince Edward Island. Notable exceptions to the usual small percentage found were in northern Ontario in 1920, and in Manitoba in 1922, when it was remarkably prevalent.

\section{Tip and Hopper BurN}

Reported from every province. The damage incurred was slight on the whole, but in Manitoba and Ontario it was occasionally severe, with a resultant loss in yield. It was most prevalent when a long dry season prevailed, but was also found when it was wet and cold, with an abundance of hoppers.

\section{Hollow Heart}

This was not of much consequence, although it was bad enough occasionally in the Maritime Provinces to justify a recommendation for closer planting. It occurred most frequently in the Irish Cobblers. 
ARSENical InJury

In Manitoba, in 1921, this occasionally occurred. In one field some plants were girdled at the surface of the ground and many others were affected less severely. The Paris Green could be recognized by its colour in the soil.

Bronzing

Under this term a trouble was reported as occurring on several farms in the Dauphin district, Manitoba, in 1921. In most cases it appeared on longcropped, rather light soils; but in one case a newly broken, almost peaty soil in a slight hollow. Where worst, the yield was seriously reduced on all but certain clearly marked areas scattered through the fields, probably representing the location of burned straw piles; in these the vines remained green. The main crop first became bronzed or purplish, and later brown, reduced in size and died prematurely. The suggestion is offered that the trouble was a form of "potash hunger."

\section{RHUBARB}

LeAf Spot-Ascochyia Rhei E. et E.

At Macdonald College, Quebec, this was present to a considerable extent in 1923.

LeAF Spot-Phyllosticta straminella Bres.

This caused some damage in southwestern Manitoba in 1923.

Anthracnose-Colletotrichum erumpens Sacc. in 1923.

There was considerable petiole infection at Macdonald College, Quebec,

Stem Rot-Botrytis $s p$.

Present at Summerland, British Columbia, in 1924, causing a distinct rotting of the petioles.

\section{Crown Rot}

A severe disease of this type and of unknown cause was reported as being severe and increasing in Saskatchewan during the five years. In 1923 it was also reported from Summerland, British Columbia, and Brandon, Manitoba.

Rоoт Rot-Fusarium sp.

\section{SOY BEAN}

A few plants were found to be affected at St. Vital, Manitoba, in 1924.

LeaF Spot-Bacterium glycineum F. C. Coerper

In 1924 it was reported as common at St. Vital, Manitoba, and in some of the variety plots at the Harrow Experimental Station, Ontario.

\section{Mosaic}

Found at Macdonald College, Quebec, in 1923 and 1924. Also at Harrow, Ontario, in 1924.

\section{SPINACH}

Downy Mildew-Peronospora effusa (Grév.) Rab.

I. Found at the Charlottetown Experimental Farm, Prince Edward Island, in one patch to the extent of 80 per cent in 1923; observed again in 1924, but not to the same extent.

Anthracnose-Colletotrichum Spinaciae E. et H.

In 1923, at Macdonald College, Quebec, the second crop was so badly affected that it was unfit for use and ploughed under. In 1924 none was observed

Rust-Puccinia subnitens Dietel

Observed in the Craigmyle District, Alberta, in 1924. 


\section{TOBACCO}

The information in this section was obtained through the courtesy of Messrs. Slagg and Major of the Tobacco Division, Central Experimental Farm, Ottawa. The review covers the years 1923 and 1924 only.

In Canada some tobacco is grown in practically all of the provinces. The commercial plantings are, however, restricted to the following counties:-

In Ontario-Essex, Kent, Elgin, Norfolk, and Middlesex Counties. In Quebec-On the north shore, Joliette, Berthier, Montcalm, L'Assomption, Two Mountains; and on the south shore, Nicolet, Iberville, St. Hyacinth, Rouville, and Missisquoi Counties.

Rоoт Roт-Thielavia basicola (B. et Br.) Zopf

In 1923, in Ontario, the effects were most noticeable towards the end of the season, although traces were found in August in about 10 per cent of the Burley fields. By the first week of September, it was fairly general in the Burley districts, but the total loss was slight.

In Quebec, in 1923, it was more prevalent than in Ontario. The greatest losses occurred on heavy, poorly drained soils, where tobacco had been cropped continuously.

In 1924 it was serious in the beds, many of them failing to produce plants fit for transplanting. In the field, it was the most destructive disease of the season, due, no doubt, to the cool and wet weather in July.

WiLT—Fusarium oxysporum (Schl.) Wolm. var. Nicotianae John.

In 1923 this type of infection was found twice in Ontario and once in Quebec.

Damping OFF-Rhizoctonia and Fusarium spp.

In 1923 it was present to a limited extent, especially in glass-covered beds. Approximately 45 per cent of the beds inspected in the Yamaska Valley, Quebec, and 75 per cent in Joliette, Quebec, were affected, with losses up to 40 per cent in infected beds.

In 1924 it was quite prevalent; cool, wet weather in May resulted in slow growth and late transplanting.

Angular Leaf Spot-Bacterium angulatum Froome et Murray

This was found for the first time in Canada in 1922 on two farms in Norfolk county, Ontario, the crops there being almost completely destroyed.

In 1923 none was found, but in 1924 it was common, particularly on the variety Canelle in Quebec, some fields showing close to 100 per cent infection.

In Ontario the disease was apparently confined to the lower leaves; the loss was inappreciable, no difference in varietal susceptibility being noted.

WiLd Fire-Bacterium Tabacum W. et F.

Up to the end of 1924 this disease had not been found in Canada.

Mosaic

In 1923, in Ontario, it was most prevalent in the flue-cured belt in southern Essex county, and to a less extent in the Burley districts of Kent and Elgin counties. Warne, Hickory, Prior, and White Burley were the most severely affected varieties. In Quebec, a small percentage was present in the majority of the fields and a few cases occurred in seed beds in Joliette and Montcalm counties.

In 1924 it was not as prevalent as in 1923. The relationships between tomato and tobacco mosaics, and between the mosaic of Physalis heterophylla Nees and tobacco mosaic were clearly demonstrated.

\section{Frenching}

Affected plants were observed occasionally. 
RING Spot

In 1923 a disease similar to the one described by Fromme, in Virg. Tech. Bull. 23, was found in Essex county, Ontario, in two fields of Broad-leaf Burley to the extent of 60 per cent and 1 per cent respectively. In 1924, it was present to a more limited extent.

RUSTS

The so-called "rusts", of uncertain origin, did no damage except in their association with plants having mosaic, where the loss from mosaic was somewhat increased by their presence.

Sunburn and Fertilizer INJURY

Did occasional damage in the seed beds. In one outstanding instance, an over application of fresh manure resulted in a condition resembling root rot.

EARLY BLOSSOMING

In 1923 an entire ten-acre field of Warne, in Essex county, Ontario, had to be ploughed up because the plants headed out when they were only about 12 inches high.

\section{TOMATO}

LEAF SPOT-Septoria Lycopersici Speg.

Reported from all provinces, Manitoba eastward, except Nova Scotia.

In Manitoba it is scarce, but at Brandon, in 1923, one patch was severely attacked. It is of common occurrence in Ontario and on the whole it caused no serious loss, but in the Niagara peninsula in 1922 many fields were defoliated, with resultant losses up to 75 per cent. In Essex county it was bad in 1924, several fields in the neighbourhood of Leamington being a total loss. In the other provinces there were occasional cases of premature defoliation, but generally of no great importance.

TARget Spot or Black Rot-Alternaria Solani (E. et M.) J. et G.

This was occasionally found in Manitoba and Ontario, but no serious injury was incurred. In Quebec, considerable damage occurred to the fruits; at Ste. Anne de la Pocatiere in 1924, 25 to 30 per cent was the estimated reduction in the crop. In New Brunswick and Prince Edward Island it occurred but the damage was slight.

LEAF Mold-Cladosporium fulvum Cke.

In a greenhouse at St. Vital, Manitoba, it caused considerable damage, and a few cases were found at the Fredericton Experimental Station, New Brunswick.

Downy MILDEw-Phytophthora infestans (Mont.) de Bary

Reported for several years in New Brunswick. It is probably more prevalent than observation would indicate.

BUCKEYE-ROT-Phytophthora terrestris Sherb.

One report, from Victoria, British Columbia, where it caused a slight loss in a greenhouse.

Wilt-Sclerotinia sclerotiorum (Lib.) Mass. (=Sclerotinia libertiana Fckl.)

In New Brunswick it was the cause of the premature death of a number of plants during the years 1920 to 1922 .

ANTHRACNose-Colletotrichum phomoides (Sacc.) Chest.

Frequently observed at the Fredericton Experimental Station, New Brunswick, in 1920 and 1921 , but none seen since.

Grand Rapids Disease-A planobacter michiganense E.F.S.

One case reported from Kelowna, British Columbia, where a small acreage was affected in 1924.

Mosaic

A few cases were noted in British Columbia and Manitoba. In Ontario it was common both in the field and in greenhouses; but the loss was small. 
In 1924, in Essex county it was present in most of the fields, with infections ranging from 2 to 65 per cent. The field having 65 per cent bordered on a patch of Burley tobacco which had a 62 per cent mosaic infection.

In Quebec it was somewhat more prevalent and destructive than in Ontario.

In New Brunswick and Prince Edward Island it occurred fairly generally, but was not severe.

Blossom ENd Rot

Reported from British Columbia, Manitoba, Saskatchewan, Ontario, and Quebec. By far the most serious losses occurred in Manitoba, and the irrigated sections of British Columbia. It is regarded there as the worst tomato disease.

\section{Streak or Winter Blight}

There was one report of its presence in Alberta. In Ontario and Quebec it was fairly common in greenhouses, and occasionally occurred in the field. When present it was responsible for a considerable reduction in the crop.

Western Yellow Blight

It was found in British Columbia, scattered throughout the tomato-growing districts from Summerland south. The average loss was 20 per cent. In 1920 it was serious in the southern Okanagan, not infrequently causing a 20 to 25 per cent loss.

\section{TURNIP}

\section{Downy MILDew-Peronospora parasitica (Pers.) de Bary}

Reported from New Brunswick only, where it is nearly always present late in the season, but with apparently no injury.

Rhizoctonia-Corticium vagum $\mathrm{B}$. et $\mathrm{C}$.

The only case recorded is in Wellington county, Ontario, where it caused considerable damage; in some fields 25 to 30 per cent of the plants were destroyed.

White Rust-Albugo candida (Pers.) Ktz.

Noted on several occasions in New Brunswick, but of no importance.

Club Root-Plasmodiophora Brassicae Wor.

Reported from all the provinces Ontario and east. In Ontario and Quebec, it is frequently found, but the reduction in yield is slight. In the Maritime Provinces, however, it is serious and responsible for much loss. No section of New Brunswick is free from it, most of the soils being somewhat acid; in the mixed farming and live stock sections, the losses are great.

In Nova Scotia an average of 25 per cent infection occurred. In Colchester county an interesting experiment was conducted, in which one-half of a field was limed and the other half not; in the former there was a trace infection and in the latter the crop was a total loss. Some resistance has been exhibited by the variety Bangholm Club Resistant.

In Prince Edward Island it was common and occasionally serious.

Storage Rots, Various

In New Brunswick there was frequently 10 to 25 per cent loss from this cause, particularly where the roots were not kept cool and well ventilated. This is believed to be due to the fact that the plants do not always mature well before harvest.

BLACK Rot-Bacterium campestre (Pammel) E.F.S.

It was present in most of the fields in New Brunswick to the extent of one-half to 1 per cent, but was not considered serious.

\section{SoFt Rot-Bacillus carotovorus Jones}

Reported from British Columbia, Manitoba, and New Brunswick. There were rare instances of a field being completely destroyed, but usually the loss did not exceed 2 per cent. 


\title{
DISEASES OF FOREST AND SHADE TREES
}

\author{
Prepared by A. W. McCallum, Forest Pathologist, Ottawa
}

ASH (Fraxinus spp.)

Lear Spots- Piggotia Fraxini B. et C.
Septoria Besseyi Pk.
Phyllosticta viridis E. et K.
Reported from Manitoba.

BALSAM FIR (Abies balsamea (L.) Miller)

Red Heart Rot-Stereum sanguinolentum Alb. et Schw.

Reported from Ontario, Quebec, and New Brunswick. This is the most serious decay affecting balsam fir. On a representative area in the Lake St. John country in Quebec where the decays of this species were studied systematically in 1923 , it was found that 28 per cent of the trees analyzed were infected with this fungus. The stand suffered no loss from this rot until the age class 61-70 was reached, but from then onward the percentage of cull steadily increased until in the age class 181-190 the amount of loss was 40 per cent of the merchantable volume of the stand. This was principally-probably 90 per cent-due to the occurrence of red rot. For the total number of tre es cut the loss from decay was approximately 20 per cent of the merchantable volume. During 1924 a similar study was carried out in the Lake Metis Seigneurie in eastern Quebec. In this district red rot was not nearly as prevalent. No loss occurred until the age class 71-80 and a negligible amount until the 101-110 year age class. The percentage of loss for the stand was 11-principally due to red rot but in part to feather rot and brown rot.

Feather Rot-Poria subacida Pers.

Present in Ontario and Quebec. This is the most important butt rot occurring in balsam fir. In the first study referred to under red heart rot, it was found that 33 per cent of the trees cut were affected with feather rot. Its importance, however, does not lie in the amount of loss which it causes directly as a result of its action in decaying wood, but rather in its rôle as a contributory cause of windthrow of affected trees. Some observations in tais connection are of interest. On an area of $2 \frac{3}{8}$ acres it was found that thirty-seven balsam firs had been first decayed by this fungus and then broken off by the wind. At this rate, in a square mile of similar forest there would be 9,970 such trees.

BRown Rot-Polyporus balsameus Pk.

Present in Ontario and Quebec. In the lake St. John region this butt rot was not found, but at Metis lake it was very common.

RED BRANCH

"The commonest theory for the cause of this disease is that of snow pressure, but it has been found that the most frequent cause is a combination of two factors, namely, insect gnawing of the bark and the subsequent drying out of the living tissues at the same level.

"This disease is of frequent occurrence in Eastern Canada. The dead, red-needled branches are conspicuous against the dark green setting of normal, living foliage.

"The insects concerned are bark beetles of the genus Monohamus. The so-called Spike Branch disease of Spruce is brought about by the same cause."(J. H. Faull.)

Partridge Rot—Trametes Pini Fr. Rare in Ontario and Quebec. 
HEART Rot-Armillaria mellea (Vahl.) Quel.

Occasionally found in Ontario as the cause of a decay of the butt.

Rooт Rot-Armillaria mellea (Vahl.) Quel.

Frequent in Ontario, apparently causing decay and death of roots.

Rusts

"Among these, the rusts which have various ferns as their secondary hosts cause the greatest damage, especially to seedlings and younger trees. The other rusts are probably of little or no economic importance at any time.

"Caeoma arctica with the alternate phase Melampsora arctica on willows has been found on balsam in Nova Scotia, but has not yet been reported from Ontario.

"The following is a list of the balsam rusts found in the Temagami Forest Reserve with their alternate hosts.

Abies Balsamea

Peridermium columnare (O and I)

Blueberry Rust of balsam

Peridermium pustulatum (O and I) Fireweed rust of balsam

Peridermium balsameum (O and I) Fern rusts of balsam
Alternate Hosts

Calyptospora columnaris (III), on Vaccinium pennsylvanicum and V. canadense

Pucciniastrum pustulatum, on Epilobium angustifolium (II and III) and E. adenocaulon (II and III)

Uredinopsis Osmundae (II and III), on Osmunda claytoniana and $\mathrm{O}$. cinnamomea

U. mirabilis II and III, on Onoclea sensibilis

U. Struthiopteridis II, on Onoclea struthipoteris

U. Phegopteridis (II and III), on Phegopteris Dryopteris

U. Atkinsonii (II and III), on Asplenium filix-foemina

Peridermium pycnogrande Bell. (O and I) U. polypodophila Bell. (II), on PolyFern rust of balsam podium vulgare

(Connection with balsam not yet established by artificial inoculations)

Peridermium pycnoconspicuum Bell. (O and I)

Fern rust of balsam

Peridermium elatinum (O and $\mathrm{I}$ )

Chickweed rust of balsam
Hyalospora Aspidiotus (II), on Phegopteris Dryopteris

Melampsorella elatina (II), on Cerastium vulgatum and Stellaria graminea"

-(J. H. Faull.)

\section{BASSWOOD (Tilia americana L.)}

Anthracnose-Gloeosporium Tiliae Oud.

Moderate infection in Prince Edward Island.

\section{BIRCH (White ANd Yellow)}

(Betula alba var. papyrifera (Marsh) Spach. and B. lutea Michx.)

Heart Rot-Fomes fomentarius Fr.

Fomes igniarius Fr.

On a representative area in northern Quebec, twenty-five average trees were selected and felled in order to secure data upon the wood rots affecting. them. In reality the birch in this area is over-mature, and from a silvicultural. 
point of view should have been taken out fifty years ago. Every tree examined was badly decayed-71 per cent by Fomes fomentarius, 8 per cent by Fomes igniarius, and 21 per cent in which both forms were present.

Somewhat similar conditions were found at lake Metis though the percentage of infected trees was not as high, the birch being on the whole not as old.

\section{BUTTERNUT (Juglans cinerea L.)}

LeAF Spot-Gnomonia leptostyla (Fr.) Ces.

Common at Macdonald College, Quebec, during 1922, 1923, and 1924, causing premature defoliation.

White Heart Rot—Fomes igniarius Fr.

Observed in Ontario.

CEDAR (Thuja occidentalis L.)

RED BRANCH (see under balsam fir)

LeAF Blight-Keithia thujina Durand

Ontario. Common in the Temagami Forest Reserve in 1919.

Rоoт Rot (see under balsam fir)

HEART Rot (see under balsam fir)

BRown Rot (see under balsam fir)

Partridge Rot (see under balsam fir)

\section{CHESTNUT (Castanea dentata (Marsh) Borkh.)}

Blight—Endothia parasitica (Murr.) And.

"This disease has practically destroyed the chestnuts in the United States, and has now made its appearance in Ontario. At the present time there are many trees diseased in Welland county, and the disease is also known to occur in Norfolk county. It is possible that it will cause very serious losses in any section where the chestnut appears in any quantity."-(R. E. Stone).

\section{CRATAEGUS spp.}

RusT-Gymnosporangium globosum Farl. Common in eastern Ontario.

\section{ELM (Ulmus americana L.)}

LeAF Stot-Gnomonia ulmea (Sacc.) Thüm.

Quebec, Ontario, and Manitoba. In eastern Quebec many trees were fairly heavily infected.

Twig Canker-Gnomonia ulmea (Sacc.) Thüm.

In a nursery at Preston, Ontario, plants 3 to 6 feet high were severely attacked.-(J. E. Howitt.)

White Heart Rot-Fomes igniarius Fr.

Observed in Ontario.

\section{HORSE CHESTNUT (Aesculus Hippocastanum L.)}

LEAF SPOT-Phyllosticta sphaeropsidea E. et E.

Ontario and Nova Scotia. In 1922 causing heavy defoliation in midsummer in southern Ontario.

\section{IRONWOOD (Ostrya virginiana (Mill.) Koch)}

White Heart Rot-Fomes igniarius Fr.

Ontario and Quebec. Very common on this species. 


\section{JUNIPERS}

RED Juniper (Juniperus virginiana L.)

Rust-Gymnosporangium globosum Farl.

Observed in Ontario.

Rocky Mountain Juniper (Juniperus horizontalis Moench.)

Rust-Gymnosporangium juvenescens Kern.

Reported from British Columbia.

MAPLES (Acer Negundo L.)

Leaf Spots-Phyllosticta Negundinis Sacc. et Speg. Septoria Negundinis Ell. et Ev.

Reported from Manitoba.

Twig Blight-Coryneum Negundinis B. et C.

In the vicinity of Guelph, Ontario, the Manitoba maples show a blighting of the young twigs caused by the above-named fungus. This is apparently the first report of this blighting in Ontario.-(R. E. Stone.)

SILVER MAPLE (Acer saccharinum L.)

TAR SPot-Rhytisma acerinum $\mathrm{F}$.

Reported from Quebec.

WrLt—Verticillium sp.

Acer saccharum Marsh.

Present in Ontario and Quebec. This injury is being observed and reported more frequently from year to year, and it will probably be found that it is an important disease of shade trees. In its early stages the symptoms resemble leaf scorch. Small trees may be killed in from two to three months from the time of infection.

LEAF SCORCH-excessive transpiration

Present in Ontario and Quebec. This form of injury is very common on the sugar maple. In dry seasons it is, of course, more pronounced, but every year a good deal of it occurs.

LeAF Spot-Phyllosticta minima (B. et C.) E. et E.

In 1923 prevalent in Stanstead county, Quebec.

\section{SYCAMORE MAPLE (Acer pseudoplatanus L.)}

LeAF SPот-Rhytisma punctatum Fr.

Reported from Quebec.

\section{OAK (Quercus macrocarpa Michx.)}

LeAF SpoT-Phyllosticta livida E. et E.

In 1923 reported from Manitoba.

\section{Quercus rubra L.)}

Brown Heart Rot-Polyporus sulphureus Fr.

Ontario and Quebec.

LEAF SCORCH-excessive transpirazion

Observed in the Temagami Forest Reserve, Ontario, in 1919. Not common on oaks.

RusT-Cronartium cerebrum (Peck) Hedge et Long

Common in the Temagami Forest Reserve. 


\section{PINES}

Pinus strobus L.

Blister Rust-Cronartium ribicola F. de Wald.

British Columbia.-Rust on white pine was observed in Stanley Park, Vancouver, in 1921 and at Agassiz in 1922.

Ontario.-Throughout southern Ontario, i.e., south of the Ottawa and French rivers, rust is widespread on both wild and cultivated Ribes though not yet observed on native pines excepting in the Niagara peninsula. In 1923 the Rainy River district was scouted, but rust was not found on either host.

Quebec.-In that part of the province south of the St. Lawrence as far east as Kamouraska county, rust is generally present on Ribes. Also, along the north shore of the St. Lawrence and up the Ottawa as far at least as opposite Mattawa.

New Brunswick.- Infection of Ribes is fairly common in southeastern New Brunswick, and diseased pines have been found in two localities.

Nova Scotia.-Infected Ribes have been reported from a number of widely separated localities, which indicates general infection. Rust on pines has been found at three different points.

Prince Edward Island.-Both pine and Ribes have been found diseased. In this province white pine is of value only as an ornamental.

\section{Pinus monticola Dougl.}

British Columbia.-Infection is now general on both hosts throughout the range of white pine on the coast. Rust on Ribes has been found about 100 miles up the coast from the nearest known white pines. The indications are that the effects of rust on western white pine will be even more marked than on the eastern species. Considerable damage has already been done to the young growth in certain localities. Rust was common on Ribes in the Dry Belt in 1923, and general throughout southeastern British Columbia. Pine infection occurs to a limited extent as yet in this part of the province.

Pinus albicaulis Engelm.

In 1923 a single infected tree of this species was found at Point Grey, near Vancouver, B.C.

Needle Blight

Pinus strobus L.

This disease is characterized by the death of the distal portion of the leaf for about half its length, though the entire leaf may die. The injury is first apparent about the time that the new leaves have completed their growth, when they suddenly assume a disuinct reddish-brown colour. This injury is connected with the death of a portion of the root system, which in turn is probably caused by a combination of shallow soil and drought. This disease is common in Ontario and Quebec.

Partridge Rot-Trametes Pini Fr.

Fairly common in Ontario.

\section{Pinus ponderosa Dougl.}

Rust—Cronartium pyriforme (Peck) Hedgc. et Long. Collected in British Columbia.

Rust-Peridermium Harknessii Moore Reported from British Columbia 
Pinus banksiana Lam.

Rust-Cronartium cerebrum (Peck) Hedgc. et Long.

Reported from several localities in Ontario. In 1919 the alternate stage of this rust was very common in the Temagami Forest Reserve, Ontario, on Quercus rubra.

Rust-Cronartium Comptoniae Arth.

The alternate stage on Myrica asplenifolia and $M$. gale has been found in the Temagami Forest Reserve, Ontario, and also at several points south of this.

\section{POPLAR}

Populus tremuloides Michx.

Blight—Napicladium Tremulae (Frank) Sacc.

Common in Manitoba, Ontario, and Quebec.

Rust-Melampsora Medusae Thüm.

Reported from Manitoba and Ontario.

LeAF Spot—Cladosporium subsessile Ell. et Barth.

Reported from Manitoba.

White Heart Rot-Fomes igniarius Fr.

Observed in Ontario and Quebec.

\section{Populus grandidentata}

Blight-See under $P$. tremuloides

White Heart Rot-See under $P$. tremuloides

Populus balsamifera L.

Leaf Spot-Septoria musiva $\mathrm{Pk}$.

Reported from Manitoba.

Populus nigra L. var. italica Duroi (Lombardy poplar)

CANker-Dothichiza populea Sacc. et Briard

Reported from Ontario and New Brunswick.

Populus sp. (Russian poplar)

Rust-See under $P$. tremuloides

Manitoba and Saskatchewan.

Populus sp.

Canker-Cytospora chrysosperma Pers.

Reported from Saskatchewan.

SASKATOON BERRY (Amelanchier alnifolia Nutt.)

RUsT-Gymnosporangium corniculans Kern

Reported from Manitoba.

Witches' Brooms-Dimerosporium Collinsii (Schw.) Thüm.

Reported from Saskatchewan. 


\section{SPRUCE}

Rusts-Melampsoropsis Cassandrae (Peck et Clint.) Arth.

Melampsoropsis abietina (A. et S.) Arth.

Both reported from Ontario.

Melampsoropsis ledicola (Peck) Arth.

Common at Norway House, Man.

Partridge Rot-Trametes Pini Fr.

Very common in Ontario and Quebec.

Red Branch-See under Balsam Fir.

\section{WILLOW}

Salix Bebbiana Sarg.

Rust-Melampsora confluens (Pers.) Jackson

Reported from Alberta. (Determined by H. S. Jackson.)

Salix spp.

Rust-Melampsora Bigelowii Thüm

Reported from Saskatchewan, Manitoba, and Ontario.

MILDEW-Uncinula Salicis (DC.) Winter

Reported from Manitoba and Ontario.

TAR SPOT—Rhytisma salicinum Fr.

Observed in Manitoba.

\section{DISEASES OF ORNAMENTAL PLANTS}

AMPELOPSIS (Ampelopsis quinquefolia Michx.)

Powdery Mildew-Uncinula necator (Schw.) E. et E.

One report of its occurrence in Bethany, Manitoba.

\section{ASTER (Callistsphus chinensis Nees)}

WiLT-Fusarium conglutinans Callistephi Beach

Reported from every province except Saskatchewan, Nova Scotia, and Prince Edward Island. It was serious, and responsible for considerable losses to amateur and commercial gardeners.

In the Raymond and Vauxhall districts of Alberta, losses up to 75 per cent were reported. Specimens and reports were received from all parts of Ontario, infections varying from 15 to 75 per cent. In Quebec it was serious and general; one infection, in 1924, of 90 per cent was reported. In New Brunswick, at the Fredericton Experimental Station, in 1923 and 1924, infections in various varieties, ranging from 20 to 90 per cent, were noted.

RusT—Coleosporium Solidaginis (Schw.) Thüm.

Slight infections were reported from south-western Manitoba in 1923 and Macdonald College, Quebec, in 1924.

Leaf Spot—Septoria Callistephi Gloyer

Common in southeastern and southwestern Manitoba in 1923, causing up to 40 per cent destruction of the leaf surface. 
Stem Rot-Sclerotinia sclerotiorum (Lib.) Mass.

(= Sclerotinia libertiana Fckl.)

Noted frequently in 1922 at the Experimental Station, Fredericton, New Brunswick.

YeLLOWS

Reported from Manitoba, Ontario, Quebec, New Brunswick, and Prince Edward Island. It was severe and caused a great deal of loss in amateur and commercial plantations. In Manitoba in 1923 and 1924 it was especially serious, entire plantings being destroyed; and the growing of asters is being discontinued in many places on account of its prevalence

\section{AZALEA}

RUST-Exobasidium Vaccinii (Fcl.) Wor.

In 1923, one case was reported from London, Ontario. Several specimens were intercepted by the inspectors at the ports of entry.

\section{BARBERRY}

(See also under Wheat)

Rust-Puccinia graminis Pers.

Reported from all the provinces except Alberta, Saskatchewan, and New Brunswick. The following dates of infection were noted:-

St. Vital, Manitoba, in 1923-June 5.

Ottawa, Ontario, in 1924-June 4.

Truro, Nova Scotia, in 1923-June 20; 1 per cent of leaves affected.

BUCKTHORN

(See also under Oats)

Rust-Puccinia coronata Cda.

Reported from Saskatchewan, Manitoba, Ontario, Quebec, and Prince Edward Island.

\section{CARNATION}

RusT-Uromyces caryophillinus (Sch.) Wint.

Reported from the Niagara peninsula, Ontario, in 1924.

\section{CHRYSANTHEMUM}

LeAF SPOT-Cylindrosporium Chrysanthemi Ell. et Dearn.

Found at Ottawa and London, Ontario. It was occasionally responsible for much defoliation.

\section{CURRANT, FLOWERING (Ribes aureum Pursh.)}

LEAF SPOT-Mycosphaerella aurea Stone (Septoria aurea E. et E.)

Found at Winnipeg, Manitoba, and Indian Head, Saskatchewan.

LeAF Spot—Phyllosticta sp.

\section{CYCLAMEN}

Rоoт Rot-Thielavia basicola (B. et Br.) Zopf

Both of these diseases caused considerable damage in the botanical greenhouses at the Central Experimental Farm, Ottawa, in 1923 and 1924.

Blight—Phoma Dahliae Berk.

\section{DAHLIA}

A specimen of this was received from Hantsport, Nova Scotia, in 1924. 


\section{DELPHINIUM}

Powdery MILDEw-Erysiphe Cichoracearum DC.

Reported as being present, and severe in some cases in British Columbia, Ontario, and New Brunswick.

\section{GLADIOLUS}

HARD RoT-Septoria Gladioli Pass.

Definite cases of this disease occurred in Ontario. Other cases were reported, but the evidence was not conclusive as to whether it was the hard rot or dry rot.

DRY ROT-A sclerotia-bearing fungus, undetermined.

Found in many plantations in Ontario and also in shipments from Holland intercepted at the ports of entry. Experiments at the Central Laboratory, Ottawa, indicate that this disease is capable of causing extensive loss.

ScAB or NeCK Rot-Bacterium marginatum McC.

Common in a number of commercial and amateur plantings in Ontario.

\section{HOLLYHOCK (Althaea rosea Cav.)}

Rust-Puccinia Malvacearum Mont.

Reported from all provinces except the three Prairie Provinces. It was extremely destructive especially in 1924; complete defoliation with abundant stem lesions and sori was common. The reports indicate that almost every plant seen by the collaborators reporting was more or less badly rusted.

LEAF SPOT-Cercospora althaeina Sacc.

Quite abundant in southeastern Manitoba in 1923.

\section{HONEYSUCKLE (Lonicera sp.)}

Powdery Mildew-Microsphaera Alni (Wall.) Salm.

Reported from Manitoba, Ontario, Quebec, and New Brunswick.

\section{IRIS}

LEAF SPOT—Heterosporium gracile (Wal.) Sacc.

Reported as abundant in Manitoba and Ontario. The infection usually occurs during the dormant period in the growth of the plants, so that the effects are seldom serious.

RHIzome RoT-Bacillus carotovorus Jones

It caused much damage in Ontario and Quebec; a small percentage was found in Prince Edward Island. Many cases were found associated with the tunnels of the Iris Rhizome Borer (Macronoctua onusta).

\section{LILAC (Syringa vulgaris L.)}

Powdery Mildew-Microsphaera Alni (Wall.) Salm.

Reported as of common occurrence and occasionally injurious in Manitoba, Ontario, Quebec, and Prince Edward Island.

\section{Blight—Botrytis Paeoniae Oud.}

\section{PEONY (Paeonia spp.)}

Reported from Saskatchewan, Manitoba, and Ontario. The secondary infections on the buds and leaves are often destructive.

Leaf and Stem Spot-Septoria Paeoniae West var. berolinensis Allesch. and 1924 .

Prevalent at Macdonald College, Quebec, during the years 1922, 1923, 
LEAF SPOT—Cladosporium sp.

LEAF SPOT-Alternaria sp.

Rоoт Rot-Fusarium spp.

Reported from Macdonald College, Quebec.

\section{PHLOX}

Powdery MILDEW-Erysiph Cichoracearum DC.

Common and quite destructive in Ontario and Quebec.

\section{ROSE}

PoWDERY MILDEW-Sphaerotheca pannosa (Wallr.) Lév.

It was common and destructive in British Columbia and Ontario. It was also reported from Quebec.

Rusts-Phragmidium spp.

Reported as common and sometimes injurious to both wild and cultivated roses in all the provinces except Alberta, Saskatchewan, and Nova Scotia.

Black Spot-Diplocarpon Rosae Wolf.

Reported as prevalent in Ontario and New Brunswick.

Lear Spot-Cercospora rosicola Pass.

Manitoba.

Destructive on native roses in both southeastern and southwestern

CANKER-Coniothyrium Wernsdorffiae Laubert

The first report of this disease in America was made in 1924, when it was found on the Crimson Rambler and Dorothy Perkins varieties at Owen Sound, Ontario, by Prof. J. E. Howitt. The plants were severely injured.

Crown Gali-Bacillus tumefaciens E.F.S. et Town.

A specimen of this was sent from Meaford, Ontario, in 1923.

\section{SNAPDRAGON}

Rust-Puccinia Antirrhini D. et $\mathrm{H}$.

Abundant and destructive on plants grown both outside and in greenhouses in Manitoba, British Columbia, and Ontario.

SPIREA

Leaf Spot-Septoria Salicifoliae (Trel.) Berl. et Vogl.

Reported from Manitoba in 1923.

Rоoт Rot-Fusarium sp.

SWEET PEA

In Ontario, it was troublesome in both greenhouses and outside.

Powdery Mildew-Microsphaera Alni (Wall.) Salm.

Reported as common in Manitoba, Ontario, and New Brunswick.

Streak-Bacillus Lathyri M. et T. in September.

It was reported from Quebec in 1922 as of frequent occurrence, especially Mosaic

Reported as slight in Quebec, New Brunswick, and Prince Edward Island.

\section{TULIP}

Blight—Botrytis Tulipae (Lib.) Hop.

Quite general, but not serious, on Vancouver Island, British Columbia. A few cases were observed in Ontario, one of which caused much loss to Darwin varieties. 


\section{DISEASES OF MISCELLANEOUS PLANTS}

Agastache Foeniculum (Pursh) Ktze.

Sphaerotheca Humuli (DC.) Burr............Fisher Branch, Man.

Agropyron albicans Scribn. et Smith

Puccinia Clematidis (DC.) Lag............ Craigmyle, Alta.

Puccinia montanensis E. et E................

Agropyron molle (Scribn. et Smith) Rydb........

Claviceps purpurea (Fr.) Tul...............

Agropyron repens (L.) Deauv.

Helminthosporium sativum (P.) K. et B..... Treesbank, Man.

Phyllachora graminis (Pers.) Fcl.............. Melbourne, Que.

Claviceps purpurea (Fr.) Tul................. Ste. Anne de la Pocatière,

Agropyron Richardsonii Schrad. P.Q.

Claviceps purpurea (Fr.) Tul............. Craigmyle, Alta.

Agropyron Smithii Rydb.

Puccinia graminis Pers...........................

Agropyron subvillosum (Hook.) E. Nelson

Claviceps purpurea (Fr.) Tul.............. Craigmyle, Alta.

Alopecurus aristulatus Michx.

Uromyces Alopecuri Seym.............. Yorkton and Ogema, Sask.

Amaranthus retroflexus L.

Albugo Bliti (Biv.) Kze................ Saskatoon, Sask.

Winnipeg, Man.

Ste. Anne de Bellevue, P.Q.

Ambrosia trifida L.

Ontario

Puccinia Xanthii Schw.......................... Man.

Anemone cylindrica A. Gray

Puccinia Clematidis (DC.) Lag............. Craigmyle, Alta.

Anemone globosa Nutt.

Puccinia Clematidis (DC.) Lag.............. “

Arabis sp.

Puccinia monoica Peck................. Treesbank, Man.

Arctium minus Bernh.

Puccinia Bardanae Cda............... Winnipeg, Man.

Artemisia biennis Willd.

Puccinia universalis Arth.............. Craigmyle, Alta.

Artemisia camporum Rydb.

Puccinia universalis Arth................ "

Artemisia Forwoodii S. Wats.

Puccinia universalis Arth................ “ "

Artemisia frigida Willd.

Puccinia universalis Arth................ "

Artemisia gnaphalodes Nutt.

Puccinia universalis Arth................ “ "

Artemisia Purshiana Besser.

Puccinia universalis Arth................. “

Aster cordifolius L.

Erysiphe Asterum.................. Inwood, Man.

Coleosporium Solidaginis (Schw.) Thüm..... Renfrew, Ont.

Avena fatua L.

Puccinia graminis Pers.................... Minto, Man. 
Beckmannia erucaeformis (L.) Host.

Erysiphe graminis DC............... Saskatoon, Sask.

Bromus ciliatus L.

Puccinia Clematidis (DC.) Lag............. Treesbank, Man.

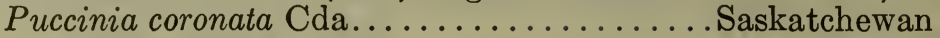

Bromus Porteri (Coult.) Nash.

Puccinia coronata Cda.................Humboldt, Sask.

Bromus Pumpellianus Scribn.

Septoria bromigena Sacc.........................

Calamagrostis inexpansa A. Gray

Puccinia coronata Cda...........................

Calamagrostis sp.

Claviceps purpurea (Fr.) Tul.............Hawoods, Sask.

Calamovilfa longifolia (Hook.) Hack.

Puccinia amphigena Diet.............. Craigmyle, Alta.

Capsella bursa-pastoris (L.) Medic.

Peronospora parasitica (Pers.) de B......... Olds, Alta.

Ste. Anne de Bellevue, P.Q.

Sudbury, N.B.

Charlottetown, P.E.I.

Carex Eleocharis Bailey

Puccinia universalis Arth.............. Craigmyle, Alta.

Chenopodium album L.

Peronospora effusa (Grev.) Rbh............. Humboldt, Sask.

Puccinia subnitens Diet............... Craigmyle, Alta.

Cirsium arvense (L.) Scop.

Puccinia obtegens (L.) Tul............. Ontario

Ogema, Sask.

Charlottetown, P.E.I.

Pyrenochaeta erysiphoides Sacc...........Winnipeg, Man.

Cirsium undulatum (Nutt.) Spreng.

Uromyces Junci Desm................ Craigmyle, Alta.

Comandra pallida A. DC.

Humboldt, Sask.

Cronartium Comandrae Pk............. Craigmyle, Alta.

Convolvulus sepium L.

Puccinia Convolvuli (Pers.) Cast............. Neepawa, Man.

Corylus americana Walt.

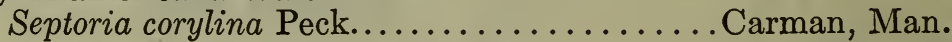

Gnomoniella Coryli (Batsch.) Sacc........... Stonewall, Man.

Corylus rostrata Ait.

Gnomoniella Coryli (Batsch.) Sacc........... Batoche, Sask.

Deschampsia caespitosa (L.) Beauv.

Puccinia coronata Cda.................. Saskatoon, Sask.

Dracocephalum parviflorum Nutt.

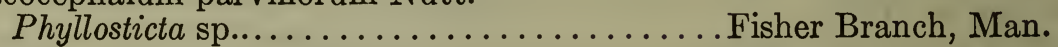

Elaeagnus commutata Bernh.

Puccinia Rhamni (Pers.) Wett........... Craigmyle, Alta.

Elymus canadensis L. Sutherland, Sask.

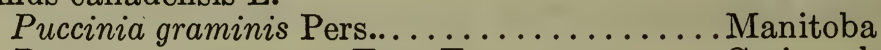

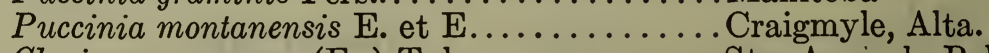

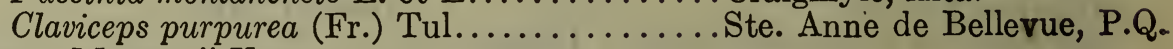

Elymus Macounii Vasey

Puccinia Clematidis (DC.) Lag............ Craigmyle, Alta.

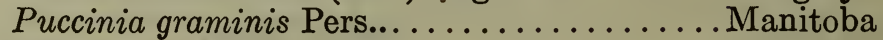

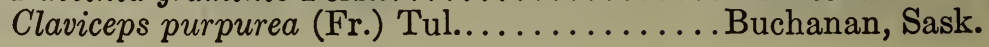


Glycyrrhiza lepidota Pursh.

Uromyces Glycyrrhizae (Rabh.) Magn........ Craigmyle, Alta.

Grossularia setosa (Lindl.) Cov. et Britt.

Puccinia Grossulariae (DC.) Lag........... Craigmyle, Alta.

Halerpestes Cymbalaria (Pursh.) Greene

Puccinia Clematidis (DC.) Lag............. Saskatoon, Sask.

Hedysarum boreale Nutt.

Craigmyle, Alta.

Uromyces Hedysari (DC.) Fckl............Binscarth, Man.

Helianthus Maximiliani Schrad.

Puccinia Helianthi Schw..............Winnipeg, Man.

Helianthus subrhomboideus Rydb.

Puccinia Helianthi Schw............... ggema, Sask.

Helianthus subterosus Bourgeau

Uromyces Junci (Desm.) Tul. . . . . . . . . . Craigmyle, Alta.

Hieracium scabriusculum Schwein.

Puccinia hieraciata (Schw.) Jack........... Crystal Springs, Sask.

Hordeum jubatum L.

Puccinia Clematidis (DC.) Lag............. Yorkton and Aberdeen,Sask.

Puccinia graminis Pers................. Saskatchewan

Manitoba

Ustilago Lorentziana Thüm.............. Craigmyle, Alta.

Scolecotrichum graminis Fcl............... Saskatoon, Sask.

Juncus ater Rydb.

Uromyces Junci (Desm.) Tul. . . . . . . . . Craigmyle, Alta.

Juncus balticus Willd.

Uromyces Junci (Desm.) Tul............. Kelliher, Man.

Lactuca pulchella Pursh.

Puccinia hemispherica (Peck.) Ell. et Ev.... Canora, Sask.

Lathyrus ochroleucus Hooker...

Uromyces Fabae (Pers.) deB..............Fisher Branch, Man.

Phyllosticta and Septoria $\operatorname{spp} \ldots \ldots \ldots \ldots \ldots \ldots$

Lathyrus venosus Muhl.

Uromyces Fabae (Pers.) deB.............. Beaver Creek, Sask.

Lepargyraea argentea (Nutt.) Greene

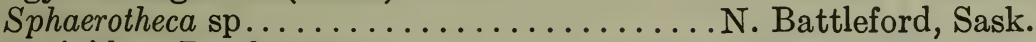

Linum rigidum Pursh.

Melampsora Lini (Pers.) Desm............. Saskatoon, Sask.

Lygodesmia juncea (Pursh.) D. Don.

Puccinia hieraciata (Schw.) Jackson ......... Saskatchewan

Puccinia Lygodesmiae Ell. et Ev. .......... Saskatoon, Sask.

Lycopus asper Greene

Puccinia Eriophori Thüm.............. Sutherland, Sask.

Malva rotundifolia $\mathrm{L}$.

Puccinia Malvacearum Mont...................... Anne de Bellevue, P.Q.

Nemexia lasioneuron (Hook.) Rydb.

Puccinia amphigena Diet......................

Oligoneuron canescens Rydb.

Puccinia Stipae Arth.

Panicularia grandis (S. Wats.) Nash.

Ustilago longissima (Sow.) Tul............ Craigmyle, Alta.

Persicaria Hartwrightii (A. Gray) Greene Saskatoon, Sask.

Puccinia Polygoni-amphibii Pers........... Craigmyle, Alta.

Persicaria Muhlenbergii (Meisn.) Small.

Puccinia Polygoni-amphibii Pers. 
Plantago major L.

Erysiphe lamprocarpa (Wallr.) Lèv..........Grandview and Winnipeg,

Poa interior Rydb.

Man.

Puccinia epiphylla (L.) Wettst............ Craigmyle, Alta.

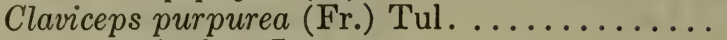

Polygonum aviculare $\mathrm{L}$.

Erysiphe Polygoni DC.............Winnipeg, Man.

Ottawa, Ont.

Ste. Anne de Bellevue, P.Q.

Polygonum Convolvulus L.

Puccinia Convolvuli Pers..............Winnipeg, Man.

Polygonum erectum L.

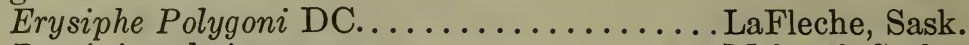

Puccinia subnitens...............................

Polygonum Muhlenbergii Watson

Puccinia Polygoni amphibii Pers...........Melville, Sask.

Polygonum Hartwrightii (A. Gray) Greene

Puccinia Polygoni-amphibii Pers.......... Craigmyle, Alta.

Potentilla bipinnatifida Dougl.

Phragmidium Potentillae (Pers.) Karst....... "6

Potentilla concinna Richards

Phragmidium Ivesiae Syd............... "

Potentilla flabelliformis Lehm.

Phragmidium Ivesiae Syd.............. "

Potentilla glomerata A. Nels.

Phragmidium Ivesiae Syd..............

Potentilla pennsylvanica L.

Phragmidium Potentillae (Pers.) Karst....... "

Prunus melanocarpa (A. Nels.) Rydb.

Podosphaera Oxyacanthae (Fr.) de B........ Beaver Creek, Sask.

Puccinellia Nuttalliana (Shultes) Hitchc.

Pyrola sp.

Puccinia Clematidis (DC.) Lag............ Craigmyle, Sask.

Melampsora Pyrolae Schröt.........................

Pyrus baccata cerasiformis

Venturia inaequalis (Cke.) Wint........... Ottawa, Ont.

Ranunculus affinis $\mathrm{R}$. Br.

Puccinia Clematidis (DC.) Lag............ Craigmyle, Alta.

Ribes Cynosbati L.

Puccinia Pringsheimiana Kleb............Parry Sound, Ont., and

Sphaerotheca Mors-uvae (Schw.) B. et C......Lanark, Ont.

Rosa arkansana Porter

Phragmidium Rosae-arkansanae Diet........ Craigmyle, Alta.

Rosa suffulta Greene

Phragmidium Rosae-acicularis Liro......... "

Rumex occidentalis S. Wats.

Puccinia ornata Arth. et Holw............. "

Sabina horizontalis (Moench.) Rydb.

Gymnosporangium corniculans Kern......... Saskatoon, Sask.

Sanicula sp.

Puccinia marylandica............... Treesbank, Man.

Smilax herbacea $\mathrm{L}$.

Solidago sp.

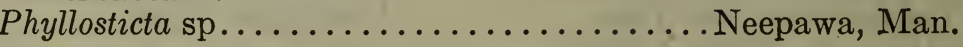

Coleosporium Solidaginis (Schw.) Thüm......Manitoba 
Solidago gilvocanescens (Rydb.) Smyth

Coleosporium Solidaginis (Schw.) Thüm...... Craigmyle, Alta.

Solidago glaberrima Martens

Coleosporium Solidaginis (Schw.) Thüm...... “ “

Puccinia Asterum (Schw.) Kern............ "

Puccinia Stipae Arth..................... "

Solidago nemoralis Ait.

Puccinia Stipae Arth..................... "

Sonchus arvensis L.

Septoria sonchifolia Cke...............Fisher Branch and

Winnipeg, Man.

Steironema ciliatum Raf.

Puccinia Distichlidis Ell. et Ev............ Yorkton, Sask.

Stipa comata Trin. et Rup.

Ustilago hypodytes (Schl.) Fr.............Beaver Creek and

Yorkton, Sask.

Stipa viridula Trin.

Puccinia substerilis................. Yorkton, Sask.

Taraxacum officinale Weber

Puccinia Taraxaci (Rabent.) Plowr......... Grandview, Man., Ontario and Quebec.

Sphaerotheca Humuli (DC.) Burr........... Winnipeg, Man.

Ramularia Taraxaci Karst.................

Thalictrum venulosum Trelease

Puccinia Clematidis (DC.) Lag............ Craigmyle, Alta.

Thalictrum sp.

Beaver Creek, Sask.

Puccinia Thalictri Chev................ Saskatchewan

Toxicoscordion gramineum Rydb.

Urtica sp.

Uromyces Zygadeni Pk................ Craigmyle, Alta.

Puccinia urticata.................... Canora, Sask.

Vicia Cracca L.

Uromyces Fabae (Pers.) de B............ Rainy River District, Ont.

Viola sp.

Puccinia Violae (Schum.) DC.............. Saskatoon, Sask.

Puccinia Ellisiana Thüm................. Sutherland,'Sask. 


\title{
APPENDIX I
}

\section{AN ANNOTATED LIST OF ANTHRACNOSES}

\author{
In the Genera: Gloeosporium, Colletotrichum, Marssonia, Septogloeum, \\ Cylindrosporium, of the Melanconiales
}

IN THE OPEN AND UNDER GLASS IN CANADA AND THE ADJOINING UNITED STATES.

Prepared by J. Dearness, M.A., London, Ontario.

The Melanconiales are a large order of the Fungi Imperfecti containing many important parasitic species. The mycelium grows within the host tissue. The fruiting mass, consisting of a flattish or shallow cup-like basal layer of fungous tissue - the stroma-with the conidia, often borne on short, narrow conidiophores, is called an acervulus, meaning a little heap. The expansion of the acervulus ruptures the cuticle or epidermis permitting the escape of the spores.

"The common name Anthracnose is applied to any disease caused by a member of this order."-(F. L. Stevens, p. 537.)

The anthracnoses come next to the rusts and smuts in importance as producers of plant diseases.

The ascigers of a number of them have been discovered. They are found in Gnomonia, Physalospora, Glomerella, and in some of the discomycetous genera.

Besides the five form-genera hereinafter synopsized, the order includes parasites in:-

Hainesia - with pezizoid or sub-tremelloid acervuli. Example-H. Lythri (Desm.) v. Höhn on Rubus, Fragaria, and other hosts.

Myxosporium - mostly on woody parts-twigs and branchlets of trees and shrubs. Examples-M. Mali, M. Pyri, M. corticolum, on malic fruit trees. .

Melanconium, brown or black spored. Examples-M. fuligineum on fruit and twigs of grape; $M$. Pandani on palms in greenhouses.

The above have non-septate conidia.

Pestalozzia, spores 2 or more septate, dark coloured and ciliate. Examples$P$. funerea on conifers and ginseng; P. uvicola on grape; P. Guepini Vaccinii on cranberry.

Coryneum, spores as in Pestalozzia but not ciliate. Examples-C. thujinum on arbor vitae; $C$. cinereum on pine.

\section{ABBREVIATIONS}

A.M...........Annales Mycologici Vols. 1 (1903)-22 .

D.............. Number in Dearness herbarium.

Dgr............. Fungous Diseases of Plants, 1909. B. M. Duggar.

Ec. F............ Exsic. Economic Fungi, Seymour and Earle.

F. Col............ Exsic. Fungi Columbiani, Ellis and others.

J.M............. Journal of Mycology, Vols. 1 (1885)-7; 8 (1902)-14.

M................ Mycologia Vols. 1 (1909)-16.

N.A.F............ Exsic. North American Fungi. Ellis and Everhart.

N.Y........... Annual Reports of the State Botanist; New York State Museum, 22 (1869)(1924).

P.P.A.......... Proceedings of the Academy of Natural Sciences, Philadelphia.

S................ Saccardo's Sylloge Fungorum.

Stv............. Fungi that cause Plant Disease, 1913. F. L. Stevens.

T.B.C........... The Journal of the Torrey Botanical Club.

Wisc........... Transactions of the Wisconsin Academy of Sciences, Arts and Letters. Papers on Parasitic Fungi. J. J. Davis. 


\section{GLOEOSPORIUM Desmazières and Montagne}

The name is suggested by the gluey masses in which the spores exude, often forming tendrils in dry weather. The almost colourless spores, ovoid, fusiform, bacillar or short oblong in shape, are borne on a stromatic cushion at first covered by the cuticle or epidermis. The conidiophores are usually short and quite narrow. The spore measurements in microns-thousands of a millimeter-are given for every species.

\section{Gloeosporium Desm. et Mont.}

1. acerinum Pass. on Acer dasycarpum, J.M. 3:21; Phleospora Aceris (Lib.) Sacc., J.M. 5:154; Septogloeum acerinum (Pass.) Sacc., F. Col. 1585. See A.M. 1924, p. 10-14, for discussion of Septomyxa acerina (West) v. Höhn. $18-22 \times 3$.

var. fructigenum E. et E. on samarae of $A$. pennsylvanicum F. Col. 681. $18-22 \times 3$.

2. Aceris Cke. on Acer rubrum Grev., $12: 26$; S. $3: 703.18 \times 5$.

3. acutiloba Dearn. et House on Hepatica, N.Y. 1919 , p. $35.4-8 \times 2-2 \frac{1}{2}$.

4. affine Ell. et Kell. on Sassafras, J.M. 3:113; syn. of Phyllosticta Sassafras Cke. Grev., 1883, p. 26; F.C. $291.5 \times 1 \frac{1}{2}$.

5. Ailanthi Dearn. et Barth. on Ailanthus, M. 9:355. 11-16 x 5-7.

6. alboferrugineum E. et E. on Acer saccharum, S. 11:562; P.P.A. 1894, p. 371. $12-14 \times 3-3 \frac{1}{2}$.

7. allantoideum Pk. on pumpkin rind, S. 11:564; N.Y. $45: 21$. 12-15 x 3-4.

8. Alni E. et E. on Alnus rugosa, S. 14:1010; Field Mus. 9:123, Ont. $12-16 \times 6-8$.

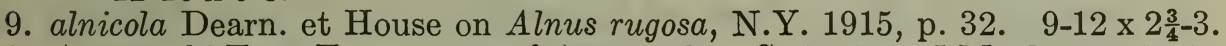

10. Amaranthi E. et E. on stems of Amaranthus, S. 18:454; J.M. 8:65. 12-15 x 5-6.

10a. amaranthicolum Dearn., on leaves of Amaranthusretroflexus (To be published). $6-8 \times 1-1 \frac{1}{2}$.

11. amentorum (Delacr.) Lind. on willow catkins (Fusarium), S. 11:650; G. Beckianum, S. 11:566; A.M. 1905, p. 341. 14-20 x 5-8. Probably the same as Calogloum Weirianum (Sacc.) Syd.

12. americanum E. et E. on Vicia, S. $11: 563$; P.P.A. 1893, p. 167; G. Ever-

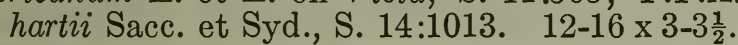

13. ampelophagum (Pass.) Sacc. on fr., leaf, and stem of grape, Stv., p. 541, N.J. Bull. 313:98. 5-6 x 2-3.

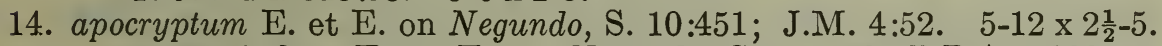

var. ramicolum E. et E. on Negundo, S. 11:563; P.P.A. 1893, p. 459. $12-15 \times 4-6$.

14a. A pocyni Dearn. et Overh. on Apocynum, D. 5654 (to be published). $10-15 \times 2 \frac{1}{2}-3$.

15. Argemonis E. et E. on Argemone, S. $10: 457$; J.M. $3: 129.22-40 \times 2 \frac{1}{2}-3$.

16. aridum Ell. et Holw. on Fraxinus americana, S. 10:452; J.M. $3: 21$. $5-8 \times 2 \frac{1}{2}-3 \frac{1}{2}$.

17. Armeriae Allesch. on Armeria, S. 14:1008. 5-9 x 2-4.

18. balsameae Davis on Abies balsamea, Wisc. 20:409. 16-33 x 4-6.

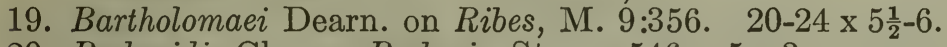

20. Berberidis Cke. on Berberis, Stv. p. $546.5 \times 3$.

21. Betae Dearn. et Barth. on sugar beets, M. $9: 356$. $3 \frac{1}{2}-5 \times 3-4$.

22. Betulae-luteae Sacc. et Dearn. on Betula lutea, A.M. $13: 125$. $6 \times 1 \frac{1}{2}$.

23. Betulae-papyriferae Dearn. et Overh. on B. papyrifera, M. 16:167. $3 \frac{1}{2}-5 \times 1.75-2$.

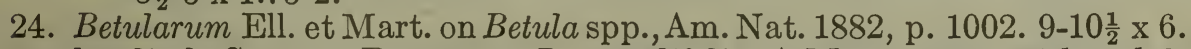

25. betulicola Sacc. et Dearn. on B. populifolia, A.M. 13:125. 6-7 $\frac{1}{2} \times 2 \frac{1}{2}-3$.

26. bicolor Davis on Quercus, bicolor Wisc. 20:427. 7-26 x 3-6. 
27. boreale E. et E. on Salix, S. 11:566; P.P.A. 1893, p. 459; M. 9:360. $7-12 \times 1 \frac{1}{2}-2$.

28. Bowmani Ell. et Dearn. on Epilobium coloratum, S. 11:564; Can. Rec. Sci. 1893, p. 270 . $5-6 \times 1 \frac{1}{2}-2$.

29. Cactorum Stonem. on cacti, S. 16:966; Bot. Gaz. 1898, p. 82 . 12-17 x 4-6.

30. canadense E. et E. on Quercus, S. 10:455; J.M. $5: 153$. 10-14 x $3 \frac{1}{2}-4 \frac{1}{2}$.

31. carpinicolum Ell. et Dearn. on Carpinus, S. 14:1011; Proc. Can. Inst.

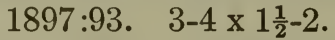

32. Caryae Ell. et Dearn. on Carya alba, S. $10: 455$; P.P.A. 1891, p. 82. $7-10 \times 1 \frac{1}{2}-2$.

Cylindrosporella Caryae (E. et D.) Petr., A.M. 1924, p. 161-2. Its asciger is Gnomonia Caryae Wolf., A. M. 1912, p. 491; M. 5:88.

33. castanicolum E. et E. on Castanea, S. 14:1011; P.P.A. 1895, p. 435. $20 \times 2-2 \frac{1}{2}$.

34. Castanopsidis Dearn. et House on Castanopsis, N.Y. 1917, p. 50.4 x $1.2-$ 1.5.

35. Catalpae E. et E. on Catalpa, S. 11:565; J.M. $7: 133$. 10-15 x 3-5.

36. caulivorum Kirch. on clover., Stv. p. 543; M. $2: 202$; N. J. Bull. $313: 98$. $12-22 \times 3-5.2$.

37. Celtidis E. et E. on Celtis, S. 10:456; P.P.A. 1891, p. 82 . 10-12 x 4-5.

38. Cerei Pass. on Cereus, J. M. 7:183.

39. Chamaedaphnis Dearn. on Chamaedaphne, M. 16:167. 15-18 x 7-9.

40. cinctum B. et C. on orchids, Sarracenia, etc., S. 3:721. (Glomerella cincta is its asciger, Stv. p. 269). $12-15 \times 2 \frac{1}{2}-4$.

41. cingulatum Atk. on Ligustrum., Cornell Bull. 49.=Glomerella cingulata (Alk.) S. et S. Stv. p. $268.10-20 \times 5-7$.

42. cladosporioides Ell. et Halst. on Hypericum, S. 10:458; J.M. 6:34. 10-14 x $3 \frac{1}{2}-4 \frac{1}{2}$.

43. concentricum Grev. spotting cabbage, cauliflower, Stv. p. 544.

44. confluens Ell. et Dearn. on Sagittaria, S. 14:1012; Proc. Can. Inst. 1897, p. $93 . \quad 8-10 \times 3-3 \frac{1}{2}$.

45. Coryli Desm. on Corylus, S. 3:43; S. 16:1004; J.M. 1:114. 12-15 x 5-7.

46. Crataegi Dearn. et Barth. on Crataegus, M. 9:356. 4-6 x 2-3.

47. crataeginum Sacc. on Crataegus Crus-galli, Ann. Myc. 13:117.

48. Cydoniae Mont. on quince, Stv. p. 542.

49. cylindrospermum (Bon.) Sacc. on Alnus (= Gnomoniella tubiformis, ill., Stv. p. 541.)

49a. cytosporeum Pass. on Populus alba, Ec. F. 192.

50. Davisii E. et E. on Vicia, S. 11: 563; P.P.A. 1893, p. 167 . $5-8 \times 3-4$.

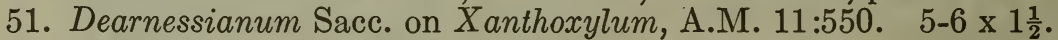

52. decipiens E. et E. on Fraxinus americana, S. $10: 453$; J. M. $3: 128$. 22-50 x 3-5.

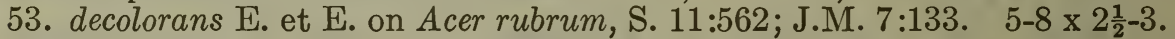

54. Diospyri E. et E. on Diospyros, S. 10:454; J. M. 3:129. 6-14 x 5-7.

55. divergens Pk. on Quercus alba, N.Y. 1911, p. 31. 10-15 x 4-6.

56. egenum Davis on Salix lucida Wisc., $21: 297$. 1-3 $\times 1-1 \frac{1}{2}$.

57. Equiseti E. et E. on Equisetum, S. 10:463; J.M. 4:52. 25-35 x 3.

58. Eriogoni E. et E. on Eriogonum, S. $14: 1010$; T.B.C. 1897 , p. 466 . 8-13 x 5-8.

59. Euphorbiae Halst. on ornamental Euphorbia, ill., N.J. Rept. 1893, p. 377.

60. Everhartii Sacc. et Syd. on Vicia, see G. americanum No. $12.12-16$ x 3-3 $\frac{1}{2}$.

61. Fagi (Desm. et Rob.) West. (var. americanum E. et E.) on beech, Stv. p. 545 , Ont. $15-20 \times 7-8$.

62. falcatum Dearn. et House, on Benzoin, N.Y. 1915, p. 33 . 24-32 x 8-12.

63. foetidophilum Stonem. on Spathyema, S. 16:1003; Bot. Gaz. 26:84. 7-15 x 2-3.

64. Fragariae (Lib.) Mont. on Fragaria Potentilla, S. 3:705; Stv. p. 542; cylindrical, 4-.. x 5-.., guttulate. 


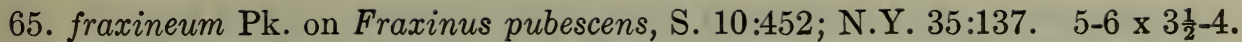
66. fructigenum Berk. on many fruits, see G. rufo-maculans, No. 135; S. 18:450. 67. fusarioides Ell. et Kell. on Asclepias, N.J. Bull. 313:100. see Colletotrichum fusarioides, M. 16:169, Ont.

68. Hamamelidis Cke. on Hamamelis, S. $3: 700$. $10 \times 2 \frac{1}{2}-3$.

69. hederaecolum Maublanc, English ivy, N.Y. 1917, p. 50.

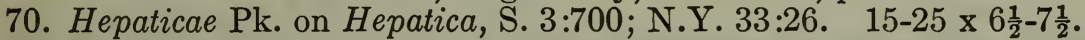

71. heterophylla E. et E. on Artemisia heterophylla, S. 18:452; J. M. 10:169. $14-18 \times 3-5$.

72. hyalino E. et E. on pear, (near G. melanconioides), S. 18:457.

73. Hydrophyli Dearn. et House, on Hydrophyllum, N.Y. 1915, p. 33, Ont. $5-9 \times 2-2 \frac{1}{2}$.

74. hysteroideum Dearn. et Barth. on Acer saccharum, M. 16 :168. 15-21 x 13-15, with bacillar conidia $4-8 \times 1 \frac{1}{2}$.

75. irregulare Pk. on Fraxinus americana, S. 10:452; N.Y. 42:31. 7-10 x 4-5.

76. laeticolor Berk. on peaches, J.M. 6:165; see G. rufo-maculans, No. 135.

77. lagenarium (Pass.) Sacc. on cucurbits, see Colletotrichum Lindemuthianum (Col. 16), var. Musarum E. et E. on banana, J.M. 5:155, Ont.

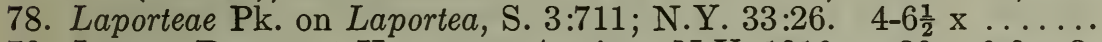

79. Lappae Dearn. et House, on Arctium, N.Y. 1916, p. 30. 6-9 × 3.

80. Lathami Dearn. on Quercus stellata, M. 16:168. $2 \frac{1}{2}-3 \times 1-1 \frac{1}{4}$.

81. Ledi Schröt. on Ledum, S. 10:454. 11-13 x 4.

82. leptospermum Pk. on Pteris, S. 10:463; N.Y. 43:32. 20-25 x 4.

83. Lindemuthianum Sacc. et Magn. on bean, see Colletotrichum No. 16, S. $3: 717$; ill., Stv. p. 548, Ont. $15-19 \times 3 \frac{1}{2}-5 \frac{1}{2}$.

84. Liriodendri E. et E. on Liriodendron, S. 10:449; J.M. 3:128. 12-16 x 5 .

85. lunatum on Opuntia, M. $8: 223$.

85a lupinicola Dearn., on Lupinus Cult. To be published. 6-12 x 3-5.

86. malicorticis Cordley, on apple, S. 16:998; Bot. Gaz. 1900, p. 57; cfr. Macrophoma curvispora Pk., T.B.C. 1900 , p. 21 ; ill. Stv. p. 542. 16-28 x 5-7.

87. Medicaginis Ell. et Kell. Medicago sativa, S. 10:459; J.M. 4:104. 15-20 x $3-4$.

88. melanconioides Pk. on pear tree, S. $18: 454 ;$ N.Y. 1899 , p. $848 ; 10-12 \times 6-7 \frac{1}{2}$. 88a melleum Dearn. et Overh., on Chenopodium album. To be published. $2 \frac{1}{2}-3 \times \frac{1}{2}$.

89. Melongenae Ell. et Halst. on egg-plant fruit, see G. rufo-maculans, No. 135.

90. minus Shear, on cranberry, S. $22: 1184$; T.B.C. 1907 , p. $315.6-9$ × 3-4.

91. Mollerianum Thm. var. asclepiadeum Sacc. on fruit of Asclepias, see Colletotrichum fusarioides, Col. 10; M. 16:169.

92. Morianum Sacc. on alfalfa, S. 10:458 (= M. Medicaginis (Voss) Magn.); S. 11:573, No. 17a; Stv. p. 543. 16-20 x 4 .

92a. multipunctatum Dearn. on Acer saccharinum L. (A. dasycarpum Ehrh.) (to be published). $6-9 \times 1 \frac{1}{4}-1 \frac{1}{2}$.

93. Musarum Cke. et Mass. on bananas, S. 10:461; Grev. 16:3, (?=Glomerella cingulata), see $G$. cingulatum, No. $41,10-12 \times 4$.

94. naviculisporum Stonem. on Rubus, S. $16: 998$; Bot. Gaz. 1898, p. 79. 12-15 x 6 .

95. necans E. et E. on Pteris, J.M. 4:104 (N.A.F. 2953 makes this syn. of G. Pteridis Hark.), see Marssonia necans $=$ Ascochyta necans (E. et E.) Davis, Wisc. $21: 273$. $12-22 \times 4-5$.

96. necator E. et E. on Rubus, S. 10:450; J.M. 3:129. 5-7 x 3 .

97. nervisequum (Fckl.) Sacc. on Platanus, S. 3:711. = Gnomonia veneta (Sacc. et Speg.) Kleb. ill., Stv. p. 274; M. 12:133; Dgr. p. 278: I.M. 5:51-58. $10-15 \times 4-6$.

98. oblongisporum Ell. et Dearn. on Acer saccharum, S. 11:562; Can. Rec. Sci. 1893, p. $270 . \quad 16-18 \times 2$.

99. obtegens Sacc. et Syd. on Pteris, A.M. 1904, p. 172 ; S. $18: 459$. 12-20 x $3-4 \frac{1}{2}$.

100. officinale E. et E. on Sassafras, S. 11:565: P.P.A. 1894, p. 370. 8-15 x 4-5. 
101. Opuntiae E. et E. on Opuntia, Stv. p. 544 ; S. 10:447. $13-18$ x 4-4.5. 101a. orbiculare Berk. on squash (fruit), N.A.F. 2670 ; S. $3: 720$. $5-9 \times 2 \frac{1}{2}-3$. 102. Osmaroniae Dearn. on Osmaronia, M. 16:168, Brit. Col. 5-7 $\frac{1}{2} \times 3-3 \frac{1}{2}$.

103. Osmundae Pk. on Osmunda cinnamomea, S. 11:568; P.P.A. 1893, p. 459; F. Col. $445.3 \times 3$.

104. ovalisporum E. et E. on Prunus serotina, S. 10:450; P.P.A. 1891, p. 83. $6-10 \times 5-7$.

105. paludosum Ell. et Galw. on Peltandra, S. $10: 462$; J.M. $6: 32$. 18-22 x 6-7.

106. paradoxum (De Not.) Fckl. on Hedera (=Trochila craterium), Stv. p. 541.

107. Pedicularis Rostr. on Pedicularis, S. 11:564. 12-15 x 3-4.

108. Pedicularis lanatae P. Henn. on P. lanata, S. $14: 1008$. $12-18 \times 3 \frac{1}{2}-4 \frac{1}{2}$.

108a. perennans Zeller et Childs producing canker on apple trees, Oreg. Bull. 217. $12-20 \times 4-6$.

109. phaeosorum Sacc. on blackberry, ref., N.Y. 1902:29, S. 3:715. 25-28 x 8 .

110. phomoides Sacc. on tomato, S. 3:718. 10-12 x 2.5-3.

111. phyllachoroides E. et E. on Artemisia, N.A.F. 3071 . 14-20 x 2.5-5.

112. Physalosporae Cav. on grapes, N.Y. 42:30. 14-20 x 4-6.

113. piperatum E. et E. on fr. "red pepper," N.J.R. 1891, p. 345; N.J. Bull. $313: 100$. 12-23 x 5-6. See Phytopathology 1926 pp. 333-345.

Its asciger is Glomerella, illus., Stv. p. 269.

114. podophyllinum E. et E. on Podophyllum, J.M. 4:103. Ovate, 12-15 x 5-7. oblong 20-35 x 4-7. A Septoriopsis.

115. Polygoni Dearn. et House on Polygonum, N.Y. 1921, p. $74 . \quad 5-7 \times 2$.

116. populinum Pk. on Populus grandidentata, S. $11: 566$; N.Y. $45: 20$. 25-40 x 3 . = Marssonia rhabdospora E. et E. Wisc., 19:674.

117. Potentillae (Desm.) Oud. on Potentilla, M. 10:262.

118. profusum E. et E. on (?) Corylus, J.M. 4:104, and Ulmus. Septogloeum fide Sacc. $25-30$ x 6-7.

The type recorded as on Corylus is said to be on Ulmus.

119. prunicolum E. et E. on Prunus virginiana, S. $10: 450$; J.M. 3:129. 4-6 $2 \frac{1}{2}$. 120. Psoraleae Pk. on Psoralea, N.Y. 1911, p. 48. 14-20 x 4-5.

121. Pteridis Hark. on Pteris, S. 3:721. See G. necans, No. 95. =G. leptospermum Pk. Wisc. 21 , p. 273 ; not G. Pteridis (Kalchb.) B. et K., S. $4: 31$. $\quad 10-24 \times 6-10$.

122. punctiforme E. et E. on Fraxinus americ., S. $10: 452$; J.M. 3:21. 15-22 x 7-8.

123. quercinum West. on Quercus, S. 3:714. $5-6 \times 2 \frac{1}{2}$.

124. quernum Hark. on Quercus, S. 3:714. 12-18 x 4-6.

125. ramosum E. et E. on Polygala Polygonum, S. $10: 459$; J.M. 5:154. 12-22 x $3-3 \frac{1}{2}$.

126. revolutum E. et E. on Robinia, S. $10: 451$; J.M. 5:153. $12-15 \times 3-4 \frac{1}{2}$.

127. rhoinum Sacc. on Rhus., M. 13:154 (Pezizella Lythri). 7-9 x 1.6-2.

128. ribicolum E. et E. on Ribes, S. 11:563; P.P.A. 1893, p. 167 . $7-12 \times 3-3 \frac{1}{2}$.

129. Ribis (Lib.) Mont. on Ribes, S. 3:706. $10 \times 5-6 .=$ Pseudopeziza Ribis Kleb., Dgr. p. 205.

130. Robergei Desm. on Carpinus, S. 3 : 712. 12-15 x 8-9.

131. Rosae Halst. on rose canes, Stv. p. 544.

132. rostratum E. et E. on Corylus, S. $10: 454$; J.M. $3: 129$. $35-45 \times 2 \frac{1}{2}-3$.

133. Rubi E. et E. on Rubus villosus, S. 10:450; J.M. 4:52. 10-16 x 4 .

134. rubicolum E. et E. on Rubus strigosus, S. 14:1006; Field Mus. 9:123. 12$16 \times 6-7$.

135. rufo-maculans (Berk.) Thm. on fruits-apples, grapes, tomatoes, etc. 10$28 \times 3 \frac{1}{2}-7$.

$=$ Nos. 66, 76, 89, 158. Stv. p. 539. (=Glomerella, Stv. p. 264-8) N.J. Bull. $313: 102$.

"Bitter-rot" of apple, fruit and branch, illus., Dgr., pp. 271-8.

In 1900 it was estimated that the apple loss in four counties in Illinois was $\$ 1,500,000$, Stv. \& Hall, p. 73 ; var. Vaccinii Shear on cranberry, U.S. Bureau of Plant Industry Bull. $110: 81, \mathrm{Pl}$. 3. $12-18 \times 4 \frac{1}{2}-6$. 


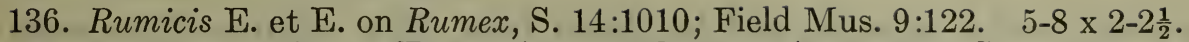

137. saccharinum E. et E. on Acer saccharum, A. nigrum, S. 10:451, P.P.A. 1891, p. $82 . \quad 6-7 \times 1 \frac{1}{2}-3$.

137a. Salicis West. on Salix, F. Col. 855, 4122; N.A.F. 2441; J.M. 1:113; M. $9: 360 . \quad 15-16 \times 7-8$.

138. Sambuci Dearn. et House, on Sambucus. = Ascochyta wisconsina Davis, Wisc., 18:101. $4-8 \times 2 \frac{1}{2}-3 \frac{1}{2}$.

139. Sanguinariae E. et E. on Sanguinaria, S. 11:562; P.P.A. 1894, p. 371. $8-15 \times 3-3 \frac{1}{2}$.

140. Sassafras (Cke.) E. et E. on Sassafras, see G. affine, No. 4, J.M. 3:113, Ont. $5 \times 1 \frac{1}{2}$.

141. Saururi Ell. et Dearn. on Saururus, S. 11:565; Can. Rec. Sci. 1893:270. $10 \times 3$.

142. Senecionis E. et E. on Senecio, S. 14:1007; T.B.C. 1897 , p. 290 . 12-23 x $3 \frac{1}{2}-4 \frac{1}{2}$.

143. septorioides Sacc. on Quercus, S. 10:455. $20 \times 1.7-2$

144. serotinum E. et E. on Prunus, S. 11:564; P.P.A. 1894, p. 371; N.A.F. 3177. $12-15 \times 4-5$.

145. stenosporum Ell. et Kell. on Populus monolifera, J.M. $2: 4$. 18-20 x $2 \frac{1}{2}$.

146. Thalictri Davis, on Thalictrum, S. 22:1177; Wisc. 16:760. 4-6 x 2-3.

May be microconidial form of Ascochyta clematidina Thm. var. Thalıctri Davis, Wisc. $20: 403$. $12-23 \times 3-6$.

147. Toxicodendri Ell. et Mart. on Rhus Tox. =Cylindrosporium No. 74, M. 8:105.

148. tremellinum Sacc. on Acer(=Hainesia = Pezizella Lythri), M. 13:146. 6-9x $1 \frac{1}{2}-2$.

149. tremuloidis E. et E. on Populus trem., S. 11:566; P.P.A. 1894, p. 370. $10-13 \times 5 \frac{1}{2}-6 \frac{1}{2}$.

150. Trifolii Pk. on Trifolium prat., N.Y. $33: 26$; S. 3:705. $15-23 \times 4-6.3$.

Davis, Wisc. 19:684, says this is probably Stagonospora Dearnessii Sacc., also Ascochyta Trifolii, Phleospora Trifolii Cav. et al.

151. Trillii E. et E. on Trillium, S. $11: 567$; P.P.A. 1894, p. $371,10-15 \times 2 \frac{1}{2}-3 \frac{1}{2}$.

152. ulmeum Miles on Ulmus, 5 spp., Bot. Gaz. 71:182. Dry, $5-6$ x 1-1 $\frac{1}{2}$; fresh, $8-10 \times 2-2 \frac{1}{2}$.

Associated with Gnomonia ulmea Schw. (E. et E. N. Am. Pyr. p. 608), the worst leaf disease of the elm.

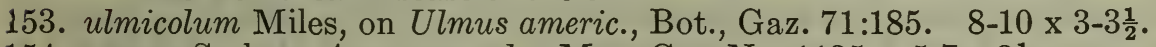

154. vagans Syd. on Acer pennsylv., Myc. Ger. No. 1135 . 5-7 x $2 \frac{1}{2}$.

155. valsoideum Sacc. on Platanus twigs., N.Y. 1911, p. 27; larger pyc. than No. 97. $11-13 \times 4$.

156. variabile Laub. on Ribes alpinum, Stv. p. 542. $25 \times 5.5-6$.

157. venetum Speg. on Rubus spp. (blackberry) syn. G. necator, J.M. 3:129, $13: 49$. $\quad 5-7 \times 3$.

157a. Veronicae Dearn. et House, on Veronica officinalis. To be published. $12-16 \times 3-3 \frac{1}{2}$.

$=$ Plectodiscella veneta, Burkholder, Phytopathology $7: 83$.

158. versicolor B. et C. on fruit of peach, S. $3: 718$; may be $G$. rufo-maculans, Stv. p. 539.

159. vexans Atk. on Melilotus, S. 14:1006; Corn. Univ. B. $97: 37$.

160. Violae B. et Br. on violets, J.M. 4:104. 8-12 × 3-5.

161. virgulatum Atk. on privet, S. $11: 565$; Corn. Univ. B. 49:314. 10-20 x 5-7.

162. yuccaegenum E. et E. on Yucca fil., S. 10:461; J.M. $3: 21$. 20-25 x 4-6.

\section{COLLETOTRICHUM, Corda}

A Colletotrichum is simply a bristle-bearing Gloeosporium. When acervuli, that would otherwise belong to the latter genus, bear few or numerous setae, usually in the margin, the fungus is referred to Colletotrichum. Bristles or 
setae may develop in some, and be absent from other cultures of the same fungus, hence a number of species have been described both as Gloeosporia and as Colletotricha.

\section{Colletotrichum, Cda.}

1. Antirrhini Stewart on Antirrhinum, Geneva, N.Y. Expt. Sta. 1900, Bull. 179, p. 105; Dgr., p. 329; Stv., p. 553. 16-21 x 4.

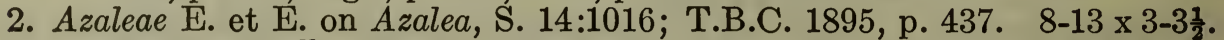

3. carpophilum Kell. et Sw. on Astragalus pods, J.M. 4:94. 16-22 × $2 \frac{1}{2}-4$.

4. cereale Manns, oats, other cereals, and grasses, Ohio Bull. 203:187; illus., Stv., p. 550; N.J. Bull. 313:104. See No. 12 . 12-26 x 3-4.

5. cinctum Stonem, on orchids (asciger, Glomerella cincta), N.J. Bull. 313:104. $12-15 \times 3-4$.

6. circinans (Berk.) Vogl. on onion (Vermicularia, F. Col. 2000), Gard. Chr. 1851, p. 595. $15-20 \times 3-4$.

7. Cyclamenae Halst. on Cyclamen (asciger, Glomerella rufo-maculans var.), Illus. N.J. Bull. 313:104. 12-15 x 4-5.

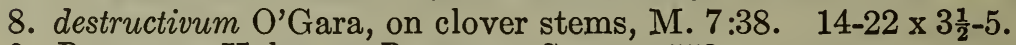

9. Dracaenae Halst. on Dracaena, Stv., p. 553.

9a. erumpens Sacc. on Rheum Rhaponticum, rhubarb cult. $25 \times 5$.

10. fusarioides (Ell. et Kell.) O'Gara on Asclepias, M. 16:169; J.M. 1:3 (=Glomerella cingulata). $17 \frac{1}{2}-35 \times 5-6$.

11. gloeosporioides Penz. on citrus plants in greenhouses, and in southern orchards, Dgr., p. 327; N.J. B. 313:104; U.S. Agr. B. 52, Stv., p. 549; severely destructive. $16-28 \times 4-6$.

12. graminicolum (Cesati) Wilson, on cereals and grasses, C. Bromi Jennings (Texas B. 9, 1890) and Nos. 4, 17, and 30 are said to be synonyms; N.J. Bull. 313:104. 18-26 × 3-4.

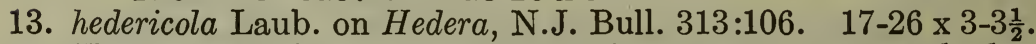

14. Helianthi Davis, on Helianthus, Wisc. $18: 89$. 25-35 $\times 2 \frac{1}{2}-3 \frac{1}{2}$.

15. lagenarium (Pass.) Ell. et Halst. on cucurbits, Dgr. p. 330; T.B.C. 1893; may be $C$. Lindemuthianum.

16. Lindemuthianum (Sacc. et Magn.) Br. et Cav., on bean, illus., Stv. p. 548; J.M. $3: 111$. $15-19 \times 3 \frac{1}{2}-5$.

The worst parasite of the bean.

17. lineola pachyspora Ell. et Kell., on grasses, N.J. B. 313:104; syn. of No. 12.

18. Lycopersici Chester, on Lycopersicum, S. 11:570; T.B.C. 1891:371; Sacc. 18.

18a. maculans (Link) Dickson on stems potato et al, M. $17: 214$. $\quad 17 \frac{1}{2}-20 \times 4-5$.

19. Malvarum (Br. et Casp.) Sacc. $=C$. Althaeae Southw., on hollyhock and other Malvoe, J.M. 6:46, 116; S. $10: 468$. 11-28 × 5.

20. Nephrolepis Faris, on Nephrolepis (Glomerella), M. 15:89-95. $12-18 \times 4-6 \frac{1}{2}$.

21. nigrum Ell. et Halst. on "capsicum fruit," S. 22:1203; N.J. R. 1885, p. 297. $18-26 \times 3-3 \frac{1}{2}$.

22. omnivorum Halst. on Aspidistra et al, S. 11:570; N.J. B. 313:108. $20-28 \times 3-5$.

23. phomoides (Sacc.) Chester, on tomato fruit, Dgr. p. 330; N.J. B. 313:108. 16-24 x 4 .

24. Pisi Patouil. on garden pea, Phytopathology $12: 500,11-18 \times$. . . .

25. Primulae Halst. on Primula, S. 14:1016.

26. Rhexiae E. et E. on Rhexia, S. 11:570; P.P.A. 1894, p. 372 . $12 \times 4$.

27. rubicolum E. et E. on canes, petioles, Rubus (=Glomerella rubicola) N.J. B. $313: 52$, Stv. p. 270 . 11-12 x 3-4.

28. Rudbeckiae Pk. on Rudbeckia, S. 18:466; N.Y. 1901:956. $12 \frac{1}{2}-15 \times 4$.

29. salmonicolor O'Gara, on Asclepias lvs. and fr., M. 7:40; M. 16:169=C. fusarioides No. 10 . $17 \frac{1}{2}-35 \times 5-6$.

30. sanguineum Ell. et Halst. on grasses, syn. of $C$. graminicolum No. 12 may be C. cereale Manns. I.M. 4:8; N.J. Bull. 313:104. 20-22 x 6.

31. Saniculae Dearn. on Sanicula, D. 4644. To be published. 20-24 x 3-4. 
32. Schizanthi Jones et Stewart on Schizanthus, Stv. p. 552.

33. Silphii Davis, on Silphium, Wisc. 19:686. 22-27 x $2 \frac{1}{2}-3$.

33a. Smilacinae Tehon et Daniels on Smilacina racemosa, M. 17:240. $19-23 \times 3-4$.

34. solanicolum O'Gara, on potato stems near and below the ground surface, M. $7: 39$. $17-22 \times 3 \frac{1}{2}-5$.

Gloeosporium Solani Ell. et Dearn. ined. from Craigellachie, B.C., in 1897, resembles this except in the setae and sclerotia. "The roots blacken and the stem sometimes falls over."-(J. A. Guignard).=C. atramentarium (Berk. et Br.) Taub. M. $17: 215$.

35. solitarium Ell. et Barth. on Solidago, S. 14:1016; T.B.C. 1897, p. 467. $12-14 \times 2 \frac{1}{2}-3$.

36. sordidum Davis, on Menispermum, Wisc. 18:265. 21-33 x 6 .

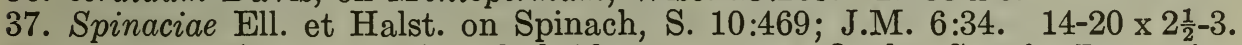

37a. tabificum (Hallier p.p.) Pethybridge, on potato, Quebec Soc. for Protection of Plants, 1924, pp. 123-137, illus. See Dickson, M. 17:213-217. $19-20 \times 3-4$.

38. Trifolii Bain, on stems of clover and alfalfa, S. 22:1201; J.M. 12:193. $11-13 \times 3-4$.

Dgr. p. 329; Stv. p. 389. "The most serious plant disease in Tennessee." -Bain.

39. Trillii Tehon, on Trillium, M. 16:141. 15-18 x 3-5.

40. vermicularia Sacc. et Dearn. on Bromus, S. 22:1207; A.M. 10:313. 20-22 x 4 . 40a. vermicularioides Halst. on Linaria, description with Ec. F. 342 . 12-15 x 4-5 41. Viciae Dearn. et Overh. on Vicia viscosa (to be published), D. 5627. $17-21 \times 3-4$.

42. Violae tricoloris R. E. Smith, on V. tricolor, S. 16:1006; Bot. Gaz. 1899, p. 203. $20 \times 5$.

N.J. Bull. 313, p. 108. 11-13 x 3-4.

43. Xanthii Halst. on stems of $X$. canadense. Description on label of Ec. F. 320 . $12-13 \times 4-5$.

MARSSONIA, Fisch.,

also written Marssonina and most frequently Marsonia, differs from Gloeosporium only in the fact that its conidia are two-celled; a septum or partition divides the plasma of the spore into two usually nearly equal portions. Sometimes the two cells are very unequal. All the species listed here are parasitic on the leaves of their hosts, rarely extending to the petioles.

1. Actaeae Bres. on Actaea, may be Ascochyta Actaeae Davis, Wisc. 19:699. $17-24 \times 5-6$.

2. apicalis E. et E. on Salix, S. 10:478; P.P.A. 1891, p. 84 . $12-20 \times 5-6$.

2a. Aquilegiae Dearn., on Aquilegia cult. To be published. 9-15 x 4 .

3. Baptisiae E. et E. on Baptisia, S. $14: 1021$; T.B.C. 1897, p. $291.14-18 \times 6-7$.

4. bracteosa Dearn. et Barth. on Ribes bracteosum, M. 9:357. 4-8 x 2-2 $\frac{1}{2}$.

5. brunnea E. et E. on Populus candicans S. 10:478; J.M. 5:154. 14-16 x 5-7.

May be M. Castagnei (Desm. et Mont.) Sacc., Wisc. 18:84, 19:705.

6. californica E. et E. on Juglans, S. 14:1022; Am. Nat. 1897, p. 429 . 20$27 \times 3$.

7. Castagnei (Desm. et Mont.) Sacc. on Populus (prob. Trochila Populorum Desm., S. 3:768; M. 2:169); said to be syn. of $M$. Populi (Lib.) Magn. No. 24.

8. Chamaenerii Rostr. on Epilobium angustifolium, S. 10:479. 28-34 x 8-9.

8a. coloradensis Dearn. et Barth., on Populus tremuloides. To be published. $10-12 \times 4-5$.

9. coronariae Sacc. et Dearn. on Pyrus coronaria, S. 22:1211; A.M. 10:313. $16-18 \times 5-6$.

syn. Ascochyta coronaria Ell. et Davis, Wisc. 14-94; each cell 9-15 x 5-8. 
10. Delastrei (de Lacr.) Magn. on Agrostemma, Lychnis, S. 3:770. 20-25 x 6-7.

11. Fraserae E. et E. on Frasera, S. $11: 574$; P.P.A. 1894, p. 373 . 12-20 x 5-6.

Sydow et Petrak, A.M. 22:397, say this is Ascochyta Fraserae Sacc. $17-26 \times 4 \frac{1}{2}-5 \frac{1}{2}$.

12. Fraxini Ell. et Davis, on Fraxinus sambucifolia, S. 18:472; Wisc. 14:97. $17-33 \times 2-3$.

13. graminicola E. et E. on grasses, S. 10:480; J.M. 5:154. 15-22 x 3-4.

Not M. graminicola Kirch., which is = M. Secalis (Oud.) Magn., S. 14:1022.

14. Juglandis (Lib.) Sacc. on Juglans, S. 3:768; (=Gnomonia leptostyla). 20-25 x 5 .

15. Kriegeriana Bres. on Salix, Wisc. $20: 404$. $13-17 \times 3 \frac{1}{2}-6$.

16. Lonicerae Hark. on Lonicera spp., J.M. 1:116. 25-30 x 6-8.

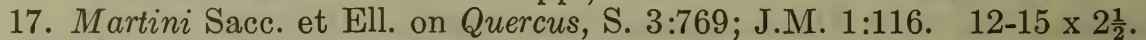

17a. Medicaginis (Voss) Magn. on alfalfa, S. 11:573; (=Gl. Morianum Sacc. No. 92). $\quad 16-20 \times 4$.

18. Meliloti Trel. on Melilotus, S. 3:771. 11-20 x 3-6.

Fide Davis, Wisc. 19:673=Ascochyta caulicola Laub. and A. lethalis, Ell. et Barth.

(=Mycosphaerella lethalis Stone, A.M. 10:587.)

19. necans (E. et E.) on Pteris, S. 10:480; J.M. 4:104. 12-22 x 4-5.

Is Ascochyta necans (E. et E.) Davis, Wisc. $21: 273$.

20. Neilliae Hark. on Spiraea spp., S. 3:769. 25-30 x 8 .

21. nigricans E. et E. on Salix, S. $10: 478$; P.P.A. 1891, p. 84 , 14-16 x 6 .

Fide Davis, Wisc. $20: 404$, the type host is Populus, and this fungus is $M$. Populi, No. 24.

22. ochroleuca B. et C. on chestnut, N.J. Bull. $313: 110$; see Septogloeum, No. 13. $20-25 \times 2 \frac{1}{2}-3$.

22a. Panattoniana (Berl.) Magnus on lettuce under glass, Lactuca. 15-20 x 3-4.

23. perforans E. et E. on lettuce under glass, S. $22: 1210$; Stv. et Hall, p. 246. $11-15 \times 2 \frac{1}{2}-3$.

24. Populi (Lib.) Magn. on Populus, S.•3:767. $\quad-20 \mathrm{x}-12$.

25. Potentillae (Desm.) Fisch. on Fragaria, S. $3: 770$. 20-25 x 7-9, 18 x 5-6,

Fide R. E. Stone, its asciger is Mollisia Earliana Sacc. var. Helleri Pk. on Drymocallis, S. 22:1211; T.B.C. 1906, p. 219 . 20-24 x 4 .

(Asciger is Venturia Potentillae (Fr.) Cke.)

var. Tormentillae Trail, on Rubus triflorus, 15-18 x 3-4.

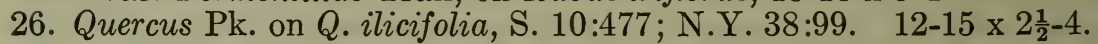

27. rhabdospora E. et E. on Populus grandidentata, S. 11:574; P.P.A. 1893, p. 168 . $20-30 \times 2$.

28. Rhamni E. et E. on Rhamnus Purshiana, S. 14:1020; P.P.A. 1895, p. 436. $6-8 \times 2 \frac{1}{2}-3$.

29. ribicola E. et E. on Ribes aurea, S. 11:574; Erythea, p. 201 . 10-14 x 5-6.

30. Rosae (Lib.) Trail, on Rosa, S. 5:424; 10:477; A.M. 10:146 (Actinonema). $18-20 \times 5$.

Asciger is Diplocarpon Rosae, Wolf, Bot. Gaz. 1912, p. 231.

31. rubiginosa E. et E. on Salix, S. $14: 1022$; P.P.A. 1895 , p. 436 . 11-13 x $2 \frac{1}{2}-4 \frac{1}{2}$.

Fide Davis, Wisc. 19:701, may be =No. 15, (Kriegeriana).

31a. Sonchi Dearn. et Bisby on Sonchus arvensis, to be published. 10-13 x 3-5.

32. stenospora (Ell. et Kell.) Sacc. on Populus, S. $10: 477$; J.M. $2: 4$. 18-20 x $2-2 \frac{1}{2}$.

33. Toxicodendri (E. et M.) Sacc., S. 10:476; J.M. 1:116. 12-15 x 5-6.

(=Cylindrosporium, No. 74), M. 8:105.

34. Veratri E. et E. on Veratrum, S. $11: 575$; P.P.A. 1894 , p. $373.18-22 \times 3-3 \frac{1}{2}$.

35. Violae (Pass.) Sacc. on Viola, Stv. p. 556. 15-18 x 5-6. 


\section{SEPTOGLOEUM Sacc.}

The conidia of Septogloeum have typically more than one septum and are sub-cylindrical or long fusoid in form. Otherwise the characters are similar to those of Marssonia and Gloeosporium. Petrak has redefined the genus in Annales Mycologici, Vol. 22:169, 1924.

1. Angelicae (Cke.) Sacc. on Angelica, S. 3:801. 40-60 × 8 .

2. A pocyni Pk. on A pocy. cannab., S. $3: 802$; N.Y. $34: 45$. $22-38 \times 2 \frac{1}{2}-4.6$.

3. Ampelopsidis (E. et E.) Sacc., on Ampelopsis, S. 10:496; J.M. 5:155, Ont. 30-35 x 4-5. A Phleospora fide Bubak Hedwigia 58:27.

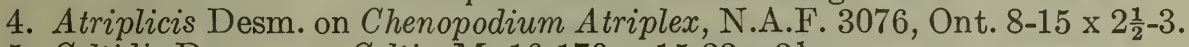

5. Celtidis Dearn., on Celtis, M. 16:170. 15-33 x $3 \frac{1}{2}$.

6. Convolvuli E. et E. on Convolvulus, S. 11:581; Erythea, 1894, p. 25. 20-36 x $3-3 \frac{1}{2}$.

7. defolians Hark., on Quercus, S. 10:496. $68 \times 4$.

7a. dimorphum Sacc., (Kriegeria Eriophori Bres. ?) on Scirpus.

8. Fraxini Hark., on Frax. oreg. (Sacc. 3082). 16-24 x 4-5̄. = Cylindrosporium californicum Earle.

9. Lupini E. et E. on Lupinus, S. 11:581; P.P.A. 1893, p. 461 . 12-22 x 4-5.

May be a form of Ascochyta Pisi, F.Col. 4506.

10. maculans Hark., on Salix lasiolepis, S. 3:803. 30-50 x 6-9.

11. Medicaginis (Rob. et Desm.) E. et E. on Medicago, P.P.A. 1893, p. 458; F.Col. $1355 . \quad 15-20 \times 3$.

Cfr. Gl. Medicaginis Ell. et Kell.

12. Nuttallii Hark. on Osmaronia S. 3:802; M. $9: 357$, B.C. $36-45 \times 4-5$.

$=$ Cylindrosporium conservans Pk. Cyl. No. 23.

13. ochroleucum (B. et C.) Dearn., on chestnut, N.Y. $1915: 51$; Marssonia No. 22. $20-25 \times 2 \frac{1}{2}-3$.

Cfr. Cryptosporium epiphyllum C. et E.

14. podophyllinum (E. et E.) Sacc., on Podophyllum, S. 10:498; J.M. 4:103. $12-15 \times 5-7$.

15. profusum (E. et E.) Sacc. on Ulmus, S. 10:497. 25-30 x 6-7.

Mississippi Bull. 38:418, type on Corylus, should be Ulmus; see Gloeosporium, No. 118.

16. querceum Davis, on Quercus bicolor, Wisc. 21:283. 35-50 x 5-7.

16a. rhopaloideum Dearn. et Bisby on Populus tremuloides, to be published. $48-60 \times 9-11$.

17. salicinum (Pk.) Sacc. on Salix sericea. S. 3:802; N.Y. 33:26; M. 9:361. $40-45 \mathrm{x} . . .$.

18. Salicis Fendlerianae Dearn. et Barth., on Salix F., M. 9:358. 15-50 x $3 \frac{1}{2}-6$.

19. Schizonoti Dearn., on Spiraea, Schizonotus, Sericotheca, M. 9:358, B.C. 30-45 x 5-7.

20. subnudum Davis, on Smilax herbacea, Wisc. $21: 297$. 20-40 x 7-11.

21. Tomassianum (Sacc.) v. Höhn. on Evonymus, Wisc. 21:260 (Bubak 381). $17-23 \times 7-14$.

\section{CYLINDROSPORIUM Unger}

The conidia are filiform or quite narrow in proportion to their length. They may be non-septate, or have one to several septa. In other respects the acervuli are like the preceding genera. In Ann. Myc. 11:541, Diedicke, and in Ann. Myc. 22:191, v. Höhnel have critically examined this genus.

1. acerinum Tr. et Earle, on Acer glabrum, S. 14:1032; Proc. Cal. Acad. 1895, p. 732 , B.C. $35-40 \times 1 \frac{1}{2}-2$.

In M. 16:164 this is referred to Septoria circinata, E. et E.

1a. acerinum Pk. on Acer pennsylvanicum, A. spicatum. I have examined the type of Septoria acerina Peck, N.Y. 25:87, 1873, and find that it is a Cylindrosporium, may be No. 13a. $30-40 \times 2 \frac{1}{2}-3$. 
2. Acori Pk. on Acorus, S. 11:584; N.Y. $46: 32$. 10-20 x 4 .

3. Alni Dearn., on Alnus tenuifolia (to be published), D. 5656, B.C. $32-45 \times 1 \frac{1}{4}-1 \frac{1}{2}$.

3a. Angelicae Dearn., on Angelica Lyallii. To be published. $40-80 \times 3-4$.

4. angustifolium Ell. et Kell. on Yucca, S. 10:505; J.M. 2:81. 65-80 x 4-5.

5. Apocyni E. et E. on Apocynum androsaemifolium, S. 10:504; J.M. 3:22. $50-80 \times 4-5$.

6. ariaefolium E. et E., on Spiraea, S. 16:1018; T.B.C. 1900, p. 575 . $35-45 \times 3 \frac{1}{2}-4$.

v. Höhn., A.M. $22: 199$, refers this to Phleospora.

7. Artemisiae Dearn. et Barth., on Artemisia, M. 9:358. 20-50 x 3-4.

Wisc. $20: 410$, sp. 40-60 long.

8. Baudysianum Sacc., on Alisma and Sagittaria, A.M. $12: 296$. $18-20 \times 2-2 \frac{1}{2}$.

Wisc. 20:420? = Rhynchosporium Alismatis (Oud.) Davis.

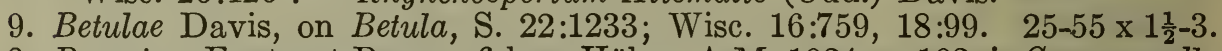

10. Brassicae Fautr. et Roum., fide v. Höhn., A.M. 1924, p. 193, is Cercosporella albomaculans E. et E., on cabbage; P.P.A. 1894, p. $378.40-65 \times 2-2 \frac{1}{2}$.

11. brevispina Dearn., on Crataegus, M. $16: 171$; M. 8:105, B.C. 45-50 x 3-4.

12. Calamagrostidis E. et E., on Calamagrostis, S. $11: 584$; P.P.A. 1893, p. 460. $40-60 \times 1 \frac{1}{2}-2$.

13. californicum Earle, on Fraxinus oreg., S. 18:492; N.Y. Bot. Gard. 1904:297, B.C. $35-40 \times 3-4$, prob. $=$ Septogloeum Fraxini Hark.

13a. canadense Bubak (= Phleospora canadensis Bubak et Dearness) on Acer spicatum, F. Col. 2374; D. 726 . $30-48 \times 2 \frac{1}{2}-3$.

14. Capsellae E. et E., on Capsella, S. 10:502; J.M. $3: 130$. 35-45 x 3 .

15. caryigenum E. et E., on Carya, S. 11:584; P.P.A. 1893, p. 168 . 25-40 x 3 .

v. Höhn., A.M. 22:201, makes this Cercosporella caryigena (E. et E.) v. $\mathrm{H}$.

16. Ceanothi E. et E., on Ceanothus, S. $10: 500$; P.P.A. 1891, p. 84. 35-45 x 4 . v. Höhn., A.M. 22:201, makes this the type species of Phloeosporella.

17. Celtidis Earle, on Celtis, S. $14: 1033$; T.B.C. 1897 , p. 29 . $20-25 \times 3$.

18. cercosporoides E. et E., on Liriodendron, S. 10:501; J.M. 3:22. 130-170 $x 3-3 \frac{1}{2}$.

19. Chrysanthemi Ell. et Dearn., on Chrysanthemum, cult., S. 11:583; Can. Rec. Sci. 1893, p. $271 . \quad 50-100 \times 3-4 \frac{1}{2}$.

v. Höhn., A.M. 22:199, says this may be an Entylomella; I have not observed anything to confirm his opinion.

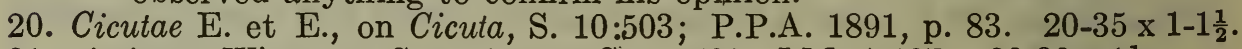
21. circinans Wint., on Sanguinaria, S. $10: 502$; J.M. $1: 127$. 20-30 $\times 1 \frac{1}{2}$.

"may be an Entylomella" v. Höhn.

22. Clematidis E. et E., on Clematis, S. 10:501; J.M. 3:22; Stv. p. 563. $75-80 \times 2 \frac{1}{2}-3$.

23. conservans Pk., on Osmaronia, =C. Nuttallii (Hark.) Dearn., M. 16:172. $30-50 \times 3$.

24. consociatum Dearn. on Acer glabrum, M. 16:172, B.C. $35-60 \times 2-2.25$.

Phleospora curvata (E. et E.) Petr. may be syn.

25. Crataegi E. et E. on Crataegus, S. $11: 582$; P.P.A. 1894, p: $372 . \quad 75-100 \times 3-3 \frac{1}{2}$.

25a. crescentum Barth., on Pastinaca sativa, description on label of F. Col. 3617 . 35-80 x 3-6. Septogloeum crescentum (Barth.) Dearn. in litt.

26. Dearnessii E. et E., on Carpinus and Ostrya, S. 10:499; P.P.A. 1891, p. 83., Ont. $35-40 \times 2 \frac{1}{2}-3$.

= Phleospora Dearnessii (E. et E.) v. Höhn., A.M. 22:200.

27. eminens Davis, on Helianthemum canadense, Wisc. $19: 687 . \quad 25-75 \times 2-3$.

28. Eryngii Ell. et Kell., on Eryngium, J.M. $3: 104$; Wisc. $17: 883$. 70-80 x 3-4.

29. Fairmanianum Sacc., on Spiraea, S. $22: 1232$; A.M. 1908, p. 566. $50-70 \times 1-2$. 
30. Filipendulae Sacc., on Spiraea, S. 3:738. 30-75 x 2-3.

fide v. Höhn. = Cercospora Spiraeae Thm.

= Phleospora dolichospora Sacc.

= Cercospora rubigo Cke. et Hark.

31. Fraxini (E. et K.) E. et E., on Fraxinus viridis, S. 10:499; J.M. 1:127. $70-100 \times 5-6$.

Davis, Wisc. 21:289-291, compares Septoria Besseyi Pk., Marssonia Fraxini Ell. et Davis, and this species.

v. Höhn., A.M. 22:200, puts this as Phloeochora Fraxini (E. et K.) v. Höhn. 31a. fraxinicolum Dearn. et House, on Fraxinus americana (1924), D. 5472. $18-30 \times 2$.

32. Gei Farlow on Geum, S. 3:738; J.M. 1:127. 75-115 x 3 .

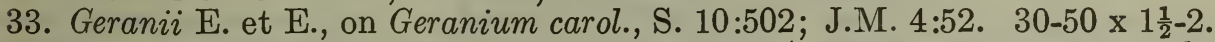

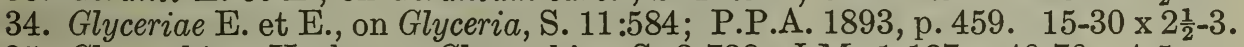

35. Glycyrrhizae Hark., on Glycyrrhiza, S. 3:738; J.M. 1:127. 40-70 x 4-5.

36. gnaphalicolum Atk., on Gnaphalium, S. 14:1033; Cornell Bull. 1897, p. 36. $50-90 \times 2 \frac{1}{2}-3$.

37. Heraclei E. et E., on Heracleum, S. 10:502; J.M. 4:52 ("40-55 x 3-4" Lind.). $20-25 \times 1$.

38. hiemalis Higgins, on cherry ( $P$. Avium, Cerasus pennsylvanicum) "shot hole" $45-65 \times 2 \frac{1}{2}-4$.

Cfr. C. Padi, No. 54, Amer. Jour. Bot. 1:164; asciger is Coccomyces hiemalis.

C. Pruni-Cerasi Massal., on P.Avium, is made the type of a new genus Libertina v. Höhn., A.M. 22:197.

39. Humuli E. et E., on Humulus, S. 10:504; J.M. 3:201. 40-50 x 3 .

40. infuscans E. et E., on Elymus, S. 18:492; J.M. 8:13. 40-55 x 3-4.

41. Iridis Ell. et Halst., on Iris, S. 10:504; J.M. $6: 34$. 15-22 × 1 .

42. Kelloggii E. et E., on Quercus Kelloggii, S. 14:1033; T.B.C. 1897, p. 291. $40-65 \times 2 \frac{1}{2}-3$.

43. Kerriae Stewart, on Kerria, Phytopathology, 1917, p. 405; asciger is Coccomyces Kerriae Stewart.

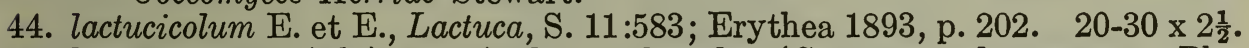

45. leptospermum (Pk.) on Aralia nudicaulis (Cercospora leptosperma $\mathrm{Pk}$., N:Y. 30:55) Wisc. 14:91. 45-90 x 1. = Septoriopsis leptosperma (Pk.) Davis, Wisc. $20: 401$.

46. longisporum Ell. et Dearn., on Lupinus, S. 11:582; Can. Rec. Sci. 1893,

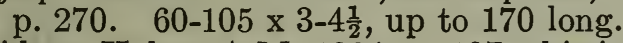

Fide v. Höhn., A.M. 1924, p. 197; this is a Cercospora.

47. Lupini E. et E., on Lupinus, S. $14: 1032$; T.B.C. 1897, p. 291 . 15-23 x $1 \frac{1}{4}-1 \frac{1}{2}$.

48. lutescens Higgins, on lvs. Prunus serotina, on lvs., fr. $P$. virginiana, $P$. Mahaleb, Jour. Am. Bot. 1:166, (asciger is Coccomyces lutescens H.). $50-87 \times 3 \frac{1}{2}-5$.

Cfr. C. Padi, No. 54.

49. microspilum Sacc. et Wint., on Quercus, S. 10:498; J.M. 1:127. 50-60 x 4.

50. minor Ell. et Kell., on Fraxinus viridis, may be=No. 81, S. 10:500, J.M. $3: 105$. 35-40 × 2-3.

v. Höhn., A.M. $22: 202$, makes this the type species of a new genus Phleosporina v. $\mathrm{H}$.

51. Negundinis E. et E. on Negundo, S. 11:582; Erythea 1894, p. 25 . 40-60 x $2 \frac{1}{2}-3$.

A Phleospora fide v. Höhn., A.M. 22:202.

52. Nuttallii (Hark.) Dearn., on Osmaronia, M. 16:172; M. 9:357, B.C. 30$50 \times 3$.

Syn. Septogloeum Nuttallii Hark., Cyl. conservans Pk. 
53. oculatum E. et E., on Populus, S. 10:499, J.M. 5:155; Wisc. 18:81-83. $30-50 \times 3$.

54. Padi Karst., on plum and cherry, Stv. p. 563; Jour. Am. Bot. 1:164-6. $48-60 \times 2-3$.

This probably covers Nos. $38,48,57$.

54a. pennsylvanicum E. et E. in litt. on Acer pennsylvanicum, A. spicatum=No. 1a.

55. Phaceliae E. et E., on Phacelia, S. 11:583; P.P.A. 1893, p. 167 . 15-40 x $3-3 \frac{1}{2}$.

55a. Phalaridis Sacc. et Dearn., on Phalaris, A.M. 13:125. 65-75 x 6-6 $\frac{1}{2}$.

56. Pomi Brooks, on apple fr. esp. Baldwin, Dgr. p. 341; T.B.C. 1908, p. 423456. $15-80 \times 2-2 \frac{1}{2}$.

57. prunophorae Higgins, on plums ( $P$. domestica, insititia, americana) Jour. Am. Bot. 1:165. 45-65 × $3 \frac{1}{2}-5$. Asciger is Coccomyces prunophorae Higgins, See No. 54 .

58. Rhamni E. et E. on Rhamnus, S. $14: 1032$; P.P.A. 1895 , p. 435 . 35-45 x $3 \frac{1}{2}-4 \frac{1}{2}$.

59. Ribis Davis, on Ribes, S. 22:1231; Wisc. $16: 759$. $50-80 \times 1 \frac{1}{2}$.

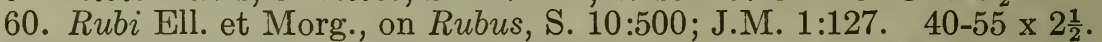

61. saccharinum E. et E., on hard maple Acer saccharinum Wang. S. 10:499;

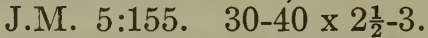

62. salicifoliae (Trel.) Davis, on Spiraea salicifolia, Wisc. 19:673, 20:428. $30-50 \times 2 \frac{1}{2}-3 \frac{1}{2}$.

63. salicinum (Pk.) Dearn., on Salix spp., N.Y. 25:87; A.M. $12: 299 ;$ M. 9:359.

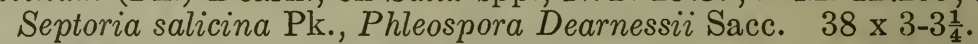

f. albaniensis (Thuem.). $33 \times 2 \frac{3}{4}-3$.

var. circinatum Dearn., on Salix lucida, M. $9: 360.40 \times 3-3 \frac{1}{2}$.

64. Scrophulariae Sacc. et Ellis, on Scrophularia, S. 3:739; J.M. 1:127. 30$40 \times 1 \frac{1}{2}-2$.

65. Shepherdiae Sacc., on Shepherdia, A.M. 11:551; Wisc. 18:105. B.C. $18-40 \times 3-4$.

65a. Sibiricum Dearn. et Bisby, on Apocynum Sibiricum. To be published. 22-45 x 2.75-3.5.

66. Smilacinae E. et E., on Smilacina, S. $16: 1018$; T.B.C. 1900 , p. $58 . \quad 50-70$ x $3 \frac{1}{2}-4 \frac{1}{2}$.

67. Smilacis E. et E., on Smilax, S. $16: 1019$; T.B.C. 1900 , p. $575 . \quad 20-30 \times 2 \frac{1}{2}$.

68. Sparganii (Pass.) E. et E., on Sparganium, Wisc. 17:882.

69. Spigeliae Dearn. et House, on Spigelia, N.Y. 1914, p. 34. 15-35 x 2.

70. spiraeicolum E. et E., on Spiraea, S. $14: 1033$; Wisc. 20:427; Am. Nat. 1897, p. 429 , B.C. $40-70 \times 3 \frac{1}{2}-5$.

71. Stachydis Ell., on Stachys, S. 11:583; J.M. 7202. 35-50 x 2.

72. Steironematis Atk., on Steironema, S. 14:1033; Conn. Bull. 1897, p. 36. $30-70 \times 1 \frac{1}{2}-2$.

73. Thalictri (E. et E.) Davis, on Thalictrum, Wisc. 17:882; J.M. 3:130. $30-60 \times 1 \frac{1}{4}$.

74. Toxicodendri (Curt.) E. et E., on Rhus Tox., S. $10: 354$; S. 11:582; P.P.A. 1893, p. 460; J.M. 1:116; J.M. 3:77; M. 8:105; N.Y. $29: 78 . \quad 21-60 \times 3-5$.

As Gloeosporium, Septoria, Marssonia, see M. 8:105.

75. Tradescantiae Ell. et Kell., on Tradescantia, S. 10:505; J.M. 2:81; Wisc. $20: 401.65-80 \times 4-5$.

76. Triostei Kell. et Sw., on Triosteum, S. 10:504; J.M. 5:73. 35-67 x 4-6.

76a. Tubeufianum Allesch., on fruit Prunus Virginiana., fide Sacc., 30-70, mostly $45-50 \times 2 \frac{1}{4}-2 \frac{3}{4}$.

77. ulmicolum E. et E., on Ulmus, Bot. Gaz. 71:190; S. 11:583; P.P.A. 1894, p. 372 . $45-65 \times 4$.

78. Urticae Dearn., on Urtica, M. $16: 173 . \quad 33-45 \times 2-2 \frac{1}{2}$. 
79. veratrinum Sacc. et Wint., on Veratrum, J.M. $1: 126$, N.B. 75-90 x 3-4. This fide v. Höhn., A.M. 1924, p. 198, is Cercosporella Veratri Peck. 80. vermiforme Davis on Alnus incana, Corylus, Wisc. 18:105. 150-250 x 4-5.

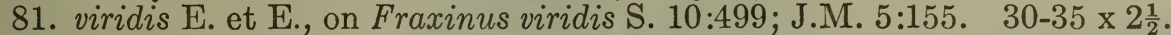
82. Ziziae E. et E., on Zizia, S. 10: 503; P.P.A. 1891, p. 83 . 40-60 x 5-6.

\section{INDEX OF HOSTS FOR THE ANTHRACNOSES}

\section{G.-Gloeosporium \\ Col.-Colletotrichum \\ M.-Marssonia \\ S.-Septogloeum \\ Cy1.-Cylindrosporium}

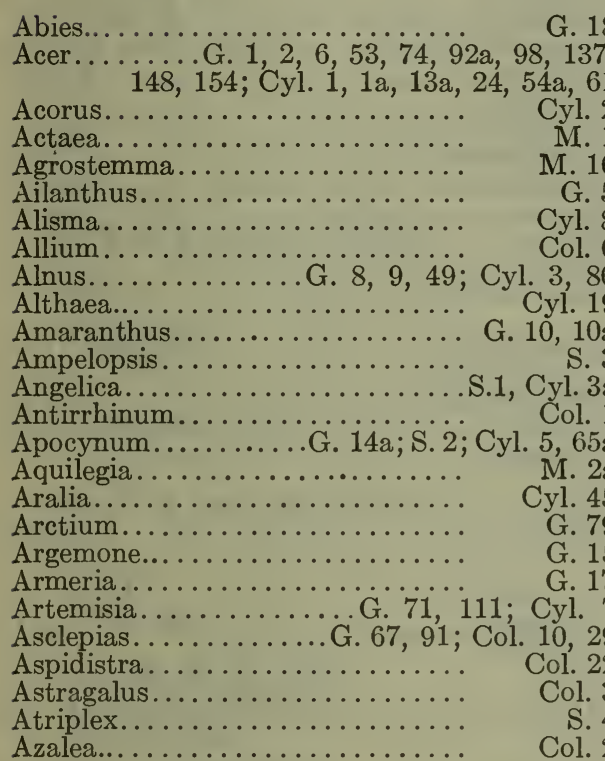

Azalea................. Col. 2

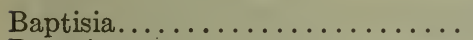

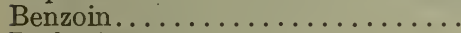

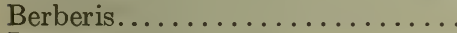

Beta. .

Betula............... 22, 23, 24, 25; Cyl. 9 Brassica.................... 43; Cyl. 10

Cacti

Capsella... G. $29,38,85,101$

Capsicum Cyl. 14 Carpinus.................. 31 , 130; Cyl. 26 Carya..................... 32 ; Cyl. 15 Castanea................. 33; M. 21; S. 13 Castanopsis................. G. 34 Catalpa.................... G. 35 Ceanothus......................... Cyl. 16 Celtis .................. 37 ; S. 5; Cyl. 17 Chamaedaphne............... G. 39 Chenopodium................... 88 . $;$ S. 4 Chrysanthemum.................... Cyl. 19 Cicuta...................... Cyl. 20 Citrus............................. Col. 11 Clematis..................... Cyl. 22 Convolvulus................. S. 6 Corylus................................ 45, 132

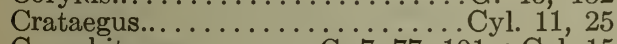
Cucurbitaceae........... 7, 77, 101a; Col. 15
Cyclamen................... Cydonia..................... G. 48

Diospyros.................... G. 54

Dracaena...................... Col. 9

Drymocallis................. M. 25

Epilobium.................G. 28; M. 8

Equisetum................. G. 57

Eriogonum................ G. G 58

Eryngium................... Cyl. 28

Euphorbia.................. G. 59

Evonymus.................. S. 21

Fagus.................. G. 61

Fragaria.................. $64 ;$ M. 25

Frasera................ M. 11

Fraxinus....... $6.16,52,65,75,122$; M. 12 ; S. 8 ; Cyl. 13, 31, 31a, 50, 81

Geranium................. Cyl. 33

Geum...................... Cyl. 32

Glycyrrhiza................. Cyl. 35

Gnaphalium................. Cyl. 36

Gramineae..Col. 4, 12, 17, 30,40 ; M. 13 ; Cyl. $12,34,40$

Hamamelis............... G. 68

Hedera..................... 69,106 ; Col. 13

Helianthemum.............. Cyl. 27

Helianthus................... Col. 14

Hepatica..................... G. 3,70

Heracleum................. Cyl. 37

Humulus..................... Cyl. 39

Hydrophyllum................ G. 73

Hypericum.................. G. G. 42

Iris.................. Cyl. 41

Juglans.................. M. 6, 14

Kerria................. Cyl. 43

Lactuca................ 22a, 23; Cyl. 44 Laportea.................... G. 78

Ledum...................... G. 81

Iigustrum.................. 41, 161

Liriodendron................ 84; Cyl. 18

Lonicera................. M. 16

Lupinus............. 85a; S. 9 ; Cyl. 46, 47

Lycopersicum............ 110, 135; Col. 18, 23

Malus........G. 66, 86, 108a, 135; Cyl. 56

Medicago................ 87 , 92; S. 11

Melilotus..................... 159; M.18 
Melongena

Menispermum

G. 89

Col. 36

G. 93

Negundo.

Nephrolepis.

G. 14 ; Cyl. 51

Col. 20

Orchids.................... 40 ; Col. 5

Osmaronia.......... 102; S. 12; Cyl. 23, 52

Ostrya.................... Cyl. 26

Osmunda.................... G. 103

Pastinaca

Cyl. 25a

Pedicularis G. 107,108

Peltandra.

G. 105

Persica G. 76,158

Phacelia. Cyl. 55

Phalaris........................ Cyl. 55a

Phaseolus...............8 3; Col. 16, 40a

Platanus.......................... 97, 155

Pisum........................... Col. 24

Podophyllum.................. 114; S. 14

Polygala....................... G. 125

Polygonum............... G. 115

Populus..G. 49a, 116, 145, 149; M. 5, 7, 8a,24, 27 , $32 ;$ S 16a; Cyl. 53

Potentilla............... 64, 117; M. 25

Primula................. Col. 25

Prunus....G. 104, 1190,144 ; Cyl. 38, 48, 54 ,

57, 76a

Psoralea................ G. 120

Pteris........... $82,95,99,121$; M. 19

Pyrus.................... 72, 88; M. 9

Quercus......G. 26, 30, 55, 80, 123, 124, 143; M. 17,26 ; S. 7, 16; Cyl. 42,49

Rhamnus.................. 28; Cyl. 58

Rheum............................... Col. $9 a$

Rhexia........................ Col. 26

Rhus............ 127, 147; M. 33; Cyl. 74

Ribes.......... 19, 156; M. 4, 29; Cyl. 59

Robinia....................... G. 126

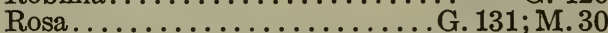

Rubus......... $94,96,109,133,134,157$;

Col. 27; M. 25; Cyl. 60

Rudbeckia.................. Col. 28

Rumex...................... G. 136
Sagittaria................... 44; Cyl. 8

Salix..... G. 11, 27, 56, 137a; M. 2, 15, 21,31:

S. 10, 17, 18; Cyl. 63

Sambucus...................... G. 138

Sanguinaria..................... 139; Cyl. 21

Sanicula............................ Col. 31

Sassafras......................... 4, 100, 140

Saururus....................... G. 141

Schizanthus..................... Col. 32

Schizonotus................. S. 19

Scirpus.................... S. $7 a$

Scrophularia................... Cyl. 64

Senecio........................ G. 142

Shepherdia...................... Cyl. 65

Silphium.................... Col. 33

Smilacina..................... 33 ; ; Cyl. 66

Smilax.................... S. 20; Cyl. 67

Solanum (potato)........... Col. 18a, 34, 37a

Solidago................... Col. 35

Sonchus....................... M.

Sparganium................... Cyl. 68

Spathyema................. G. 63

Spigelia........................ Cyl. 69

Spinacia................... Col. 37

Spiraea........ M. $_{20} ;$ S. $19 ;$ Cyl. $6,29,30,62,70$

Stachys.................... Cyl. 71

Steironema..................... Cyl. 72

Thalictrum................. 146; Cyl. 73

Tormentilla........................ M. 25

Tradescantia................... Cyl. 75

Trillium.............. 36,$150 ;$ Col. 8, 39

Triosteum................... Cyl. 76

Ulmus.......G. 118, 152, 153; S. 15; Cyl. 77

Urtica.................... Cyl. 78

Vaccinium.................. G. 90, 135

Veratrum................. 34 ; Cyl. 79

Veronica.................... G 157a

Vicia................ $12,50,60$; Col. 41

Viola................. 160; Col. 42; M. 35

Vitis..................... 13, 112, 135

Xanthium.................... Col. 43

Xanthoxylum.................... G. 51

Yucca..................... 162; Cyl. 4

Zizia................. Cyl. 82 


\title{
APPENDIX II
}

\section{THE PARASITIC FUNGI FOUND IN MANITOBA}

\author{
G. R. Bisby, I. L. Conners, and D. L. Bailey
}

This list includes the fungi and bacteria found to be parasitic upon wild and cultivated hosts in Manitoba, and serves as a summary of our plant disease survey activities during the past five years.

The report of a parasite is represented by one or more herbarium specimens in practically every case. In some instances, portions of the specimens have been submitted to specialists for determination: Dr. John Dearness and Dr. J. J. Davis deserve special mention because of their assistance with difficult identifications. The records are considered to be accurate except in those few instances in which question marks are appended to indicate uncertainty; these marks are placed before names that are in some doubt; when placed after the name of a fungus, uncertainty regarding its parasitism is indicated.

A very few records are from Kenora or Minaki, Ontario, only: these are specified. Cultivated plants are indicated by the abbreviation "cult:" or by the use of the common name.

This list of 520 records upon 281 hosts includes 14 bacteria, 21 Phycomycetes, 43 Ascomycetes, 143 Fungi Imperfecti, 25 smuts, 104 rusts, and 6 other Basidiomycetes, a total of 356 species of parasites.

The names of wild host plants have been taken from Rydberg or Britton and Brown, as used by Jackson, Higham \& Groh in their check list of Manitoba Flora. The names of cultivated plants are principally as given in Bailey's "Manual of Cultivated Plants."

\section{Parasites of vascular plants. (See parasites of fungi and insects below).}

Abies balsamea (L.) Mill.

Melampsorella elatina (A. et S.) Schw.

Acer Negundo $L$.

Lentinus lepideus Fr.

Phyllosticta Negundinis Sacc. et Speg.

Pleurotus ulmarius Fr.

Septoria Negundinis Ell. et Ev.

Acer spicatum Lam.

Phyllosticta minima (B. et C.) Ell. et Ev. (Minaki)

Rhytisma punctatum (Pers.) Fr. (Minaki)

Uncinula circinata Cke. \& Pk.

Actaea alba (L.) Mill.

Puccinia Clematidis (D.C.) Lag.

Actaea rubra (Ait.) Willd.

Puccinia Clematidis (DC.) Lag.

Ramularia Actaeae Ell. et Hol.

Agastache anethiodora (Nutt.) Britt. Sphaerotheca Humuli fuliginea (Schl.) Salm.

Agropyron caninum (L.) R. et S. Claviceps purpurea (Fr.) Tul.

Puccinia graminis Pers.

Agropyron cristatum (cult.) Claviceps purpurea (Fr.) Tul. Puccinia graminis Pers.

Agropyron repens (L.) Beauv. Claviceps purpurea (Fr.) Tul. Puccinia graminis Pers.

Agropyron Richardsonii Schrad. Claviceps purpurea (Fr. Tul.)

Puccinia graminis Pers.
Agropyron Smithii Rydb.

Ascochyta graminicola Sacc.

Claviceps purpurea (Fr.) Tul.

Puccinia graminis Pers.

Puccinia montanensis E. et E.

Agropyron tenerum Vasey

Claviceps purpurea (Fr.) Tul.

Puccinia Clematidis (D.C.) Lag.

Puccinia graminis Pers.

Ustilago Agropyri Clint. in litt.

Agrostis alba L.

Erysiphe graminis DC.

Agrostis stolonifera L.

Erysiphe graminis DC.

Alisma subcordata Raf.

Cladochytrium Alismatis Buesg.

Rhynchosporium Alismatis (Oud.) Davis

Allium Cepa L (Cult.)

Botrytis Allii Munn

Urocystis Cepulae Frost

Alnus incana (L.) Moench Septoria alnifolia E. et E.

Alopecurus aristulatus Michx. Uromyces Alopecuri Seym.

Alopecurus pratensis L Puccinia graminis Pers.

Althaea rosea Cav. (Hollyhock) Cercospora althaeina Sacc. Septoria malvicola E. et M.

Amaranthus retroflexus L. Albugo Bliti (Biv.) Kze.

Alternaria? Solani (E. et M.) J. et G. 
Ambrosia trifida L.

Entyloma Compositarum Farl.

Erysiphe Cichoracearum DC.

Puccinia Xanthii Schw.

Ambrosia sp.

Plasmopara Halstedii (Farl.) Berl. et De T.

Amelanchier alnifolia Nutt.

Dimerosporium Collinsii (Schw.) Thüm.

Gymnosporangium? juvenescens Kern

Gymnosporangium ? clavariaeforme (Jacq.) DC.

Amorpha canescens Pursh, Uropyxis Amorphae (M.A. Curt.) Schroet.

Andropogon furcatus Muhl.

Puccinia Ellisiana Thuem.

Sphacelotheca occidentalis (Seym.) Clint.

Anemone canadensis L.

Puccinia Clematidis (DC.) Lag.

Antirrhinum majus L. (cult.)

Puccinia Antirrhini D. et $\mathrm{H}$.

Apium graveolens L. (Celery)

Bacillus carotovorus Jones

Septoria Petroselini A pii Br. et Cav.

Apocynum androsaemifolium $\mathrm{L}$.

Cercosporella A pocyni (E. et K.) Trel.

Arabis sp.

Puccinia monoica Peck.

Aralia nudicaulis L.

Nyssopsora clavellosa (Berk.) Arth.

Arctium minus Schk.

Puccinia Bardanae Corda

Argentinia Anserina (L.) Rydb.

Ramularia arvensis Sacc.

Artemisia gnaphalodes Nutt.

Cylindrosporium Artemisiae D. et Barth.

Puccinia Absinthii DC.

Puccinia universalis Arth.

Asclepias sp.

Colletotrichum fusarioides (Ell. et Kell.) O'Gara

Asparagus officinalis L. (cult.)

Puccinia Asparagi DC.

Aster laevis L.

Coleosporium Solidaginis (Schw.) Thüm.

Aster Lindleyanus T. et G.

Erysiphe Cichoracearum DC.

Aster novae-angliae L.

Puccinia Asteris Duby

Aster spp.

Coleosporium Solidaginis (Schw.) Thüm.

Puccinia Asterum (Schw.) Kern.

Avena fatua L.

Puccinia graminis Pers.

Avena sativa L. (cult.)

Helminthosporium Avenae Eidam

Leptosphaeria avenaria Weber

Puccinia graminis Pers

Puccinia Rhamni (P. coronata Cda.)

Ustilago Avenae (Pers.) Jens.

Ustilago levis (K. et S.) Magn.

Beckmannia erucaeformis (L.) Host.

Puccinia graninis Pers.

Puccinia Rhamni (Pers.) Wettst.

Ustilago striaeformis (West.) Niessl.

Berberis vulgaris L. (cult.)

Puccinia graminis Pers.

Beta vulgaris L. (cult.)

Phoma Betae Fr.

Betula spp.

Polyporus betulinus Bull.

Bidens frondosa $\mathrm{L}$.

Septocylindrium concomitans (E. \& H.) Hals.
Brassica oleracea var. botrytis L. (Cauliflower) Bacillus carotovorus Jones

Brassica oleracea var, capitata L. (Cabbage) Bacillus carotovorus Jones.

Brassica sp. Albugo candida (Pers.) Kze.

Briza maxima $\mathrm{L}$ Puccinia graminis Pers.

Bromus ciliatus L.

Puccinia Clematidis (DC.) Lag.

Puccinia Rhamni (Pers.) Wettst.

Bromus inermis Leyss (Cult.) Claviceps purpurea (Fr.) Tul.

Septoria Bromi Sacc.

Septoria bromigena Sacc.

Bromus latiglumis (Shear) Hitch. Puccinia Clematidis (DC.) Iag.

Bursa Bursa-pastoris (L.) Britton Peronospora parasitica (Pers.) Tul.

Calamagrostis canadensis (Michx.) Beauv. Claviceps purpurea (Fr.) Tul Puccinia Rhamni (Pers.) Wettst.

Calamovilfa longifolia (Hook.) Hack. Puccinia amphigena Dietel

Callistephus chinensis Nees. (cult. Aster) Coleosporium Solidaginis (Schw.) Thüm. Fusarium conglutinans Callistephi Beach Septoria Callistephi Gloyer

Caltha palustris L. Puccinia calthaecola Schr.

Carex Douglasii Boot. Puccinia universalis Arth.

Carex durifolia Bailey Puccinia eminens Kern

Carex praegracilis W. Boott. Puccinia universalis Arth.

Carex Sartwelli Dewey Puccinia Peckii (De T.) Kell.

Carex scoparia Schk. Puccinia Asterum (Schw.) Kern

Carex varia Muhl. Cintractia Caricis (Pers.) Magn.

Carex vesicaria $\mathrm{L}$. Phyllosticta Caricis (Fckl.) Sacc. Septoria Caricis Pass. Stagonospora? albescens Davis

Carex spp. Puccinia Grossulariae (Schum.) Lagerh. $P$. hieraciata (Schw.) Jackson $P$. urticata (Link) Kern

Celastrus scandens $\mathrm{L}$. Ramularia Celastri E. et M.

Cerastium arvense L. Melampsorella elatina (A. et S.) Schw.

Chaetochloa glauca (L) Scribn. Ustilago neglecta Niessl.

Chaetochloa sp.

Piricularia? grisea (Cke.) Sacc. Sclerospora graminicola (Sacc.) Schroet.

Chamaesyce sp. Uromyces proeminens (DC.) Pass.

Chamaenerion angustifolium Scop. Puccinia gigantea P. Karst Puccini Castrum Abieti-chamaenerii Kleb. Pucciniastrum Abieti-Chamaenerii Kleb. Ramularia punctiformis (Schl.) Hoehn.

Cheirinia cheiranthoides (D.) Link Peronospora parasitica (Pers.) Tul.

Chrysanthemum sp. (cult.) Oidium Chrysanthemi Rab.

Cicuta maculata L. Puccinia Cicutae Thuem. 
Cirsium arvense (L.) Scop. Albugo Tragopogonis (DC.) S.F.G. Pyrenochaeta? erysiphoides Sacc. Sclerotinia sclerotiorum (Lib.) Massee

Cirsium Flodmanii (Rydb.) Arth. Puccinia Cirsii Lasch.

Clematis sp. Cylindrosporium Clematidis E. et E.

Comandra pallida A. DC.

Cronartium Comandrae Peck.

Puccinia Androgogonis Schw.

Convolvulus sepium L.

Puccinia Convolvuli (Pers.) Cast.

Septoria Convolvuli Desm.

Cornus stolonifera Michx.

? Phyllactinia corylea (Pers.) Karst.

Septoria cornicola Desm.

Corylus americana Walt.

Gnomoniella Coryli (Batsch) Sacc.

Septoria corylina Peck

Crataegus spp.

Gymnosporangium? germinale (Schw.) Kern Phyllosticta Crataegi (Cooke) Sacc.

Cucumis sativus L. (cult.)

Bacterium lacrymans Sm. et Bryan

Bacillus tracheiphilus E. F. S.

Cladosporium cucumerinum $\mathbf{E}$. et A.

Dactylis glomerata $\mathrm{L}$

Claviceps purpurea (Fr.) Tul.

Puccinia graminis Pers.

Dasystephana Andrewsii (Griseb.) Small Asteroma Gentianae Fckl.

Daucus Carota var. sativa DC. (cult.) Sclerotinia sclerotiorum (Lib.) Massee

Delphinium (sult.) Erysiphe Polygoni DC.

Diervilla Diervilla (L.) MacMill Septoria ? diervillicola E. et E. (Minaki)

Distichlis stricta (Torr.) Rydb. Puccinia subnitens Diet.

Doellingeria umbellata (Mill.) Nees. Coleosporium Sclidaginis (Schw.) Thuem.

Eleagnus argentea Pursh. Aecidium Allenii Clint.

Eleocharis sp.

Puccinia Eleocharidis Arth.

Elymus canadensis L.

Claviceps purpurea (Fr.) Tul.

Phyllachora graminis (Pers.) Fckl.

Puccinia Clematidis (DC.) Lagerh.

Puccinia graminis Pers.

Puccinia montanensis Ellis.

Elymus innovatus Beal Claviceps purpurea (Fr.) Tul

Elymus Macounii Vasey

Claviceps purpurea (Fr.) Tul.

Puccinia Clematidis (DC.) Lagerh.

Puccinia graminis Pers.

Elymus virginicus L.

Phyllachora graminis (Pers.) Fckl.

Elymus sp.

Urocystis Agropyri (Preuss.) Schr.

Epilobium adenocaulon Haussk. Pucciniastrum Epilobii (DC.) Otth.

Eupatorium purpureum L. Puccinia Eleccharidis Arth.

Falcata comosa (L.) Kuntze Woroniella aecidioides (Peck) Syd.

Festuca elatior L.

Puccinia graminis Pers.
Fragaria spp. (cult. and wild)

Botrytis? cinerea Pers.

Ramularia Tulasnei Sacc.

Rhizopus nigricans Ehr.

Fraxinus pennsylvanica Marsh

Fomes igniarius $\mathrm{Fr}$.

Hysterographium Fraxini (Pers.) De Not.(?)

Phyllosticta viridis E. et K.

Piggotia Fraxini B. et C.

Septoria Besseyi Pk.

Galium boreale L.

Puccinia rubefaciens Johans.

Glycyrrhiza lepidota Nutt. Uromyces Glycyrrhizae (Rab.) P. Magn.

Grindelia squarrosa (Pursh) Dunal Puccinia Asterum (Schw.) Kern

Hedysarum boreale Nutt.

Uromyces Hedysari-obscuri (DC.) Carest. et Picc.

Helenium autumnale $\mathrm{L}$.

Septoria Helenii E. et E.

Helianthus annuus L. (sult.)

Erysiphe Cichoracearum DC.

Puccinia Helianthi-mollis (Schw.) Jackson

Sclerotinia sclerotiorum (Lib.) Massee

Septoria Helianthi E. et K.

Helianthus petiolaris, Nutt. Septoria Helianthi E. et K.

Helianthus tuberosus $\mathrm{L}$.

Sclerotinia sclerotiorum (Lib.) Massee

Heracleum lanatum Michx.

Phyllosticta Heraclei E. et D.

Ramularia Heraclei (Oud.) Sacc.

Hieracium canadense Michx.

Puccinia hieraciata (Schw.) Jackson

Holcus Sorghum sudanensis Hitchc. (cult.)

Bacillus Sorghi Burr.

Piricularia? grisea (Cke.) Sacc.

Hordeum jubatum L.

Erysiphe graminis DC.

Puccinia Clematidis (DC.) Lagerh.

Puccinia graminis Pers.

Ustilago Lorentziana Thuem.

Hordeum vulgare L. (cult.)

Bacterium translucens J. J. et R.

Claviceps purpurea (Fr.) Tul.

Erysiphe graminis DC.

Helminthosporium gramineum Rab.

Helminthosporium sativum P. K. et B.

Helminthosporium teres Sacc.

Puccinia anomala Rostr.

Puccinia graminis Pers.

Septoria Passerinii Sacc.

Ustilago Hordei (Pers.) K. et S.

Ustilago nuda (Jens.) K. et S.

Humulus lupulus L.

Phyllosticta Humuli Sacc. et Speg.

Impatiens spp.

Plasmopara obducens Schr.

Puccinia Impatientis (Schw.) Arth.

Iris sp. (cult.)

Heterosporium gracile (Wal.) Sacc.

Iva xanthifolia Nutt.

Basidiophora Kellermanii (E. et H.) Wilson

Sclerotinia sclerotiorum (Lib.) Massee

Septoria ivaecola E. et E.

Juncus balticus Willd.

Uromyces Junci (Desm.) Tul.

Juncus filiformis L.

Uromyces Junci (Desm.) Tul. 
Juniperus sibirica Burgsd. Gymnosporangium germinale (Schw.) Kern

Lactuca pulchella (Pursh) D.C. Bremia Lactucae Regel

Puccinia hemisphaerica (Peck.) E. et E.

Lactuca sativa L. (cult.)

Alternaria sp.

Botrytis cinerea Pers.

Puccinia hieraciata (Schw.) Jackson

Sclerotinia sclerotiorum (Lib.) Massee

Lathyrus ochroleucus Hook.

Uromyces Fabae (Pers.) de Bary

Lathyrus odoratus L. (cult.)

Microsphaera ? diffusa Cke. et Peck

Rhizoctonia Solani Kuehn.

Lathyrus venosus Muhl. Cercospora Lathyri D. et $\mathrm{H}$. Septoria Astragali Rob.

Ledum groenlandicum Oeder Melampsoropsis ledicola (Peck) Arth.

Leontodon Taraxacum L. Puccinia Taraxaci (P. Hieracii (Schum.) Mart.)

Ramularia Taraxaci Karst.

Sphaerotheca Humuli fuliginea (Schl.) Salm.

Lepargyraea argentea (Nutt.) Greene Cercospora manitobana Davis

Lepargyraea canadensis (L.) Greene Aecidium Allenii Clinton

Lepidium densiflorum Schrad. Peronospora parasitica (Pers.) Tul.

Linum Lewisii Pursh Melampsora Lini (Schum.) Desm.

Linum usitatissimum L. (cult.) Fusarium Lini Bolley Melampsora Lini (Schum.) Desm.

Lonicera glaucescens Rydb. Cercospora antipus E. et $\mathrm{H}$.

Lonicera spp. Microsphaera Alni (Wall.) Salm.

Lychnis chalcedonica L. (cult.) Septoria Melandrii Pass.

Lycopersicum esculentum L. (cult.) Alternaria Solani (E. et M.) J. et G. Cladosporium fulvum Cke. Septoria Lycopersici Speg.

Lygodesmia juncea (Pursh) D. Don. Puccinia Grindeliae Peck

Malva rotundifolia $\mathrm{L}$. Septoria heterochroa Desm.

Malvastrum coccineum (Nutt.) A. Gray Puccinia Sherardiana Koern.

Matteuccia Struthiopteris (L.) Tod. Uredinopsis Struthiopteridis Stoerm.

Medicago sativa L. (cult.) Ascochyta Medicaginis Bres. Peronospora Trifoliorum de B. Pleosphaerulina Briosiana Pol. Pseudopeziza Medicaginis (Lib.) Sacc. Pyrenopeziza Medicaginis Fckl. Sclerotinia sclerotiorum (Lib.) Massee

Melilotus alba Desr. (cult.) Ascochyta Meliloti (Trel.) Davis Cercospora Davisii Ell. et Ev.

Menispermum canadense Cercospora Menispermi E. et $\mathrm{H}$. Entyloma Menispermi Farl. et Trel.

Mentha canadensis L.

Puccinia angustata Peck. Puccinia Menthae Pers.

Mentha glabrior (Hook.) Rydb. Puccinia Menthae Pers.
Micrampelis lobata (Michx.) Greene Septoria Sicyi Peck

Monarda fistulosa L.

Puccinia Menthae Pers

Muhlenbergia mexicana (L.) Trin. Phyllachora graminis (Pers.) Fckl.

Nabalus albus (L.) Hook.

Puccinia hieraciata (Schw.) Jackson

Septoria? Nabali B. et C.

Naumburgia thyrsiflora (L.) Duby Puccinia lysimachiata (Link) Kern.

Nicotiana sp. (Ornamental) Alternaria sp.

Oenothera biennis L. Puccinia Peckii (De Toni) Kell. Septoria Oenotherae West.

Padus virginiana (L.) Mill. Cylindrosporium lutescens Higgins Phyllosticta virginiana (E. et H.) Seaver Podosphaera Oxyacanthae (DC.) de Bary

Paeonia sp. (cult.) Botrytis Paeoniae Oud.

Panicularia grandis (S. Wats.) Nash Claviceps purpurea (Fr.) Tul.

Panicum capillare L.

Phyllachora graminis (Pers.) Fckl.

Panicum miliaceum L.

Sorosporium Syntherismae (Peck) Farl.

Parthenocissus quinquefolia (L.) Planch. Uncinula necator (Schw.) Burr.

Pastinaca sativa L. (cult.)

Sclerotinia sclerotiorum (Lib.) Massee

Pelargonium (cult.)

? Bacillus caulivorus Pril. \& Del.

Botrytis cinerea Pers.

Persicaria Hartwrightii (A. Gray) Greene Puccinia Polygoni-amphibii Pers.

Persicaria Muhlenbergii (Meisn.) Small Puccinia Polygoni-amphibii Pers.

Phalaris arundinacea L.

Puccinia Majanthae (Schum.) Arth.

Phalaris canariensis L. (cult.)

Puccinia graminis Pers.

Phaseolus vulgaris L. (cult.)

Colletotrichum Lindemuthianum (Sacc. et Magn), Br. et Cav.

Pseudomonas Phaseoli E. F. S.

Phleum pratense L.

Claviceps purpurea (Fr.) Tul.

?Heterosporium Phlei Gregory

Puccinia graminis Pers.

Scolecotrichum graminis Fckl

Phragmites Phragmites (L.) Karst.

Puccinia Magnusianum Koern.

Puccinia rubella (Pers.) Arth.

Ustilago sp.

Physalis heterophylla Nees.

Puccinia Physalidis Pk.

Physalis virginiana Mill.

Puccinia Physalidis Pk.

Picea Abies Karst. (cult.)

Peridermium coloradense (Diet.) Arth. et Kern

Picea Mariana (Mill.) B.S.P.

Melampsoropsis ledicola (Peck) Arth.

Pinus Banksiana Lamb

Coleosporium? Solidaginis (Schw.) Thuem.

Hypodermella ampla (Davis) Dearn.

Lophodermium Pinastri (Schr.) Chev.

Pisum sativum L. (cult.)

Ascochyta Pisi Lib.

Colletotrichum Pisi Pat. 
Pisum sativum L. (cult.)-con. Erysiphe Polygoni DC.

Pseudomonas Pisi Sack. Septoria flagellifera Ell. \& Ev. Septoria Pisi West. Uromyces Fabae (Pers.) de Bary

Plantago major L. Erysiphe Cichoracearum DC. Septoria Plantaginis Pass.

Poa arida Vasey Puccinia Clematidis (DC.) Lagerh.

Poa pratensis L. Claviceps purpurea (Fr.) Tul. Colletotrichum cereale Manns. Erysiphe graminis DC.

Puccinia epiphylla Wettst. (P. Poarum Niels.) Sporotrichum Poae $\mathrm{Pk}$.

Polygonum aviculare $\mathrm{L}$. Cercospora avicularis Wint. Erysiphe Polygoni DC. Uromyces Polygoni (Pers.) Fckl.

Populus balsamifera L. Septoria musiva Pk.

Populus tremuloides Michx. Cladosporium subsessile Ell. et Barth. Fomes igniarius Fr. Napicladium Tremulae (Fcl.) Sacc. Septoria musiva $\mathrm{Pk}$.

Populus spp. Cytospora chrysosperma (Pers.) Fr. Melampsora? Medusae Thuem. Uncinula Salicis (DC.) Wint.

Portulaca oleracea L. Albugo Portulaceae (DC.) Kuntze

Potentilla bipinnatifida Dougl. Phragmidium Potentillae (Pers.) Karst.

Potentilla glabrella Rydb. Phragmidium Potentillae (Pers.) Karst.

Potentilla pennsylvanica $\mathrm{L}$. Phragmidium Potentillae (Pers.) Karst.

Potentilla strigosa Pall. Phragmidium Potentillae (Pers.) Karst.

Prunus Besseyi Bailey Sclerotinia cinerea (Bon.) Wor.

Prunus pennsylvanica L.f. Exoascus Pruni Fckl. Cylindrosporium hiemale Higg.

Prunus spp. (cult. and wild) Cephalothecium roseum Cda. ?Cladosporium carpophilum Thuem. Cylindrosporium hiemale Higg. Exoascus Pruni Fckl. Nectria cinnabarina (Tode) Fr. (?) Plowrightia morbosa (Schw.) Sacc. Podosphaera Oxyacanthae (DC.) de Bary Saccharomyces sp.

Sclerotinia cinerea (Bon.) Wor. Stereum purpureum Pers.

Pulsatilla ludoviciana (Nutt.) Heller Polythelis Pulsatillae (Rostr.) Arth. Urocystis Anemones (Pers.) Wint.

Pyrola americana Sweet Melampsoropsis Pyrolae (DC.) Arth. Pucciniastrum Pyrolae (Pers.) Diet.

Pyrus Malus L. (cult.)

Bacillus amylovorus (Burr.) Trev. Penicillium spp.

Physalospora Cydoniae Arn. Venturia inaequalis (Cke) Wint.
Quercus macrocarpa Michx. Marssonia Martini (Sacc. et Ell.) Magn. Microsphaera Alni (Wallr.) Wint. Phyllosticta livida E. \& E.

Radicula palustris (L.) Moench. Albugo candida (Pers.) Kuntze

Ranunculus abortivus L. ?Puccinia Eatoniae Arth.

Ranunculus Macounii Britton Uromyces Alopecuri Seym.

Ranunculus sceleratus L. Uromyces Alopecuri Seym.

Raphanus sativus L. (cult.) Albugo candida (Pers.) Kuntze Pythium de Baryanum Hesse

Rhamnus alnifolia L'Hér. Puccinia Rhamni (Pers.) Wettst.

Rhamnus cathartica L. (cult.) Puccinia coronata Corda

Rheum Rhaponticum L. (Cult.) Phyllosticta straminella Bres.

Ribes nigrum L. (cult.)

Puccinia Grossulariae (Schum.) Lagerh. Septoria Ribis Desm.

Ribes odoratum Wendl. (cult.) Septoria aurea E. et E.

Ribes spp. (cult. and wild) Puccinia Grossulariae (Schum.) Lagerh. Septoria Ribis Desm.

? Sphaerotheca Mors-uvae (Schw.) B. et C.

Roripa Armoracia Hitchc. (cult.) Ramularia Armoraciae Fckl.

Rosa acicularis Lindl. Phragmidium Rosae-acicularis Liro

Rosa blanda Ait., R. spp. (wild) Cercospora rosaecola Pass.

Earlea speciosa (Fr.) Arth.

Phragmidium montivagum Arth.

Rosa spp. (cult.)

Phragmidium americanum Diet.

Phragmidium disciflorum (Tode) J. F. James ? Sphaerotheca pannosa (Wallr.) Lév.

Rubus strigosus Michx.

Didymosphaeria manitobiensis $\mathrm{E}$. et $\mathrm{E}$.

Phragmidium imitans Arth.

Rubus triflorus (R. pubescens Raf.)

Discosia artocreas (Tode) Fr. (?)

Gymnoconia interstitialis (Schl.) Lagerh.

Pucciniastrum arcticum (Lag.) Tranz.

Rubus spp. (cult. \& wild)

Coniothyrium Fuckelii Sacc.

Phoma sp. (Mycosphaerella rubina (Pk) Jacz.)

Septoria Rubi (Mycosphaerella Rubi Roark) Sphaerotheca Humuli fuliginea (Schl.) Salm.

Rudbeckia laciniata L.

Phyllosticta Rudbeckiae E. et E.

Plasmopara Halstsdii (Farl.) Berl. et de T.

Ramularia Rudbeckiae Pk.

Septoria Rudbeckiae E. \& H.

Uromyces Rudbeckiae A. et $\mathrm{H}$.

Rumex crispus L.

Ramularia decipiens $\mathrm{E}$. et $\mathrm{E}$.

Rumex mexicanus Miesn.

Puccinia rubella (Pers.) Arth.

Rumex occidentalis S. Wats.

Puccinia rubella (Pers.) Arth.

Salix spp.

Fomes igniarius Fr.

Melampsora Bigelowii Thuem. 
Salix spp.-con. Rhytisma salicinum Fr. Septoria ? salicina $\mathrm{Pk}$. Uncinula Salicis (DC.) Winter

Sanicula marylandica L. Puccinia marylandica Lindl

Schizachyrium scoparium (Michx.) Nash Puccinia Andropogonis Schw.

Scirpus microcarpus Presl. Puccinia angustata Peck.

Scolochloa festucacea (Willd.) Link Claviceps purpurea (Fr.) Tul. Puccinia Rhamni (Pers.) Wettst.

Secale cereale L. (cult.) Claviceps purpurea (Fr.) Tull. Erysiphe graminis DC. Puccinia Asperifolii (Pers.) Wetts. Puccinia graminis Pers. Urocystis occulata (Wallr.) Rab.

Sium cicutaefolium Gmel. Fusicladium depressum (B. et Br.) Sacc.

Smilax herbacea L.

Puccinia amphigena Diet.

Stagonospora Smilacis (E. et M.) Sacc.

Vermicularia Liliacearum West.

Soja max Piper (cult.)

Bacterium glycineum Coerper or B. Sojae Wolf

Fusarium sp.

Solanum Melongena L. (cult.) Alternaria sp.

Solanum tuberosum L. (cult.) Actinomyces scabies (Thaxt.) Güssow Alternaria Solani (E. et M.) J. et G. Bacillus atrosepticus v. Hall Colletctrichum atramentarium (B. et B.) Taub. Corticium vagum B. et C.

Fusarium coeruleum (Lib.) Sacc.

Fusarium discolcr sulphureum (Schl.) A. et W.

Fusarium oxysporum Schl.

Spondylocladium atrovirens Harz

Stysanus stemonitis Corda (?)

Verticillium albo-atrum McA.

Solidago spp.

Coleosporium Solidaginis (Schw.) Thuem.

Puccinia Asterum (Schw.) Kern

Sonchus arvensis L.

Sclerotinia sclerotiorum (Lib.) Massee Septoria sonchifolia Cke.

Sorbus americana Marsh Gymnosporangium cornutum (Pers.) Arth.

Spartina cynosuroides (L.) Roth.

Claviceps purpurea (Fr.) Tul.

Spartina Michauxiana Hitchc.

Puccinia Distichlidis E. et E.

Uromyces acuminatus Arth.

Spiraea alba Du Roi

Septoria Salicifoliae (Trel.) E. et E.

Stachys palustris L.

Erysiphe Galeopsidis DC.

Steironema ciliatum (L.) Raf.

Phyllosticta decidua E. et K.

Puccinia Distichlidis E. et E.

Septoria conspicua E. et M.

Stipa comata Trin. et Rup.

Puccinia Stipae Arth.

Stipa viridula Trin.

Puccinia substerilis E. et E.

Ustilago hypodytes (Schl.) Fries
Symphoricarpos spp.

Microsphaera diffusa Cke. et Pk.

Puccinia abundans (Peck) Jackson Septoria Symphoricarpi E. et E.

Syringa vulgaris L. (Lilac) Microsphaera Alni (Wallr.) Wint.

Thalictrum dasycarpum Fisch. et All. Puccinia Clematidis (DC) Lagerh.

Thalictrum venulosum Trel. Polythelis Thalictri (Chev.) Arth. Puccinia Clematidis (DC.) Lagerh.

Tiniaria cilinodis (Michx.) Small Ramularia cilinodis (Minaki)

Tiniaria Convolvulus (L.) Webb et Moq. Puccinia Polygoni-amphibii Pers. Septoria Polygonorum Desm. Ustilago anomala (Kuntze) Wint.

Torresia odorata (L.) Hitchc. Puccinia graminis Pers.

Toxicodendron radicans (L.) Kuntze Cercospora rhoina C. et E. Pileolaria Toxicodendri (B. et R.) Arth.

Trientalis americana Pursh Septorià increscens Pk. (Minaki)

Trifolium hybridum L. (cult.) Polythrincium Trifolii Kze. Uromyces hybridi Davis

Trifolium medium L. (cult.) Uromyces Trifolii (Hedw.) Lév.

Trifolium pratense L. (cult.) ?Erysiphe Polygoni DC.

Uromyces Trifolii (Hewd.) Lév.

Trifolium repens L. (cult.) Cercospora zebrina Pass. Polythrincium Trifolii Kze. Uromyces Trifolii repentis (Cast.) Liro

Trisetum spicatum (L.) Richter Puccinia monoica (Peck) Arth.

Triticum spp. (wheat) Bacterium atrofaciens $\mathrm{McCulloch}$

Bacterium translucens undulosum S. J._et: Cladosporium graminum Corda (?)

Claviceps purpurea (Fr.) Tul.

Erysiphe graminis DC.

Fusarium culmorum (W. Sm.) Sacc.

Giblerella Saubinetii (Mont.) Sacc.

Helminthosporium sativum P. K. et B.

Puccinia graminis Pers.

Puccinia triticina Eriks.

Septoria nodorum Berk.

Septoria Tritici Desm.

Tilletia laevis Kuehn

Tilletia Tritici (Bjerk.) Wint.

Ustilago Tritici (Pers.) Jens.

Ulmus americana $\mathrm{L}$.

Gnomonia Ulmea (Schw.) Thuem.

Pleurotus ulmarius Fr. (?)

Unifolium canadense (Desf.) Greene Puccinia Majanthae (Schum.) A.'. et H.

Urtica gracilis Ait.

Puccinia urticala (Link) Kern

Ramularia Urticae Ces.

Vaccinium sp.

Calyptospora columnaris (A. et S.) Kuehn (Minaki)

Vagnera stellata (L.) Morong

Phyllosticta Convallariae Pers.

Puccinia Majanthae (Schum.) A. et H.

Uromyces acuminatus Arth.

Viburnum Lentago L.

Microsphaera Alni (Wallr.) Wint. 
Viburnum Opulus L.

Cercospora Opuli (Fel.) v. $\mathrm{H}$.

Vicia americana Muhl.

Peronospora Viciae (Berk.) de Bary

Uromyces Fabae (Pers.) de Bary

Uromyces porosus (Peck) Jackson

Viola tricolor var. hortensis DC. (cult.)

Cercospora Violae-tricoloris Br. et Cav.

Sphaerotheca Humuli fuliginea (Schl.) Salm.
Viola spp.

Puccinia Ellisiana Thuem.

Puccinia Violae (Schum.) DC.

Zea Mays L. (cult.) Bacillus Sorghi Burr Puccinia Sorghi Schw. Ustilago Zeae (Beck.) Ung.

Zizia aurea (L.) Koch Puccinia Angelicae (Schum) Fckl.

\section{Parasites of fungi and insects.}

Lactarius piperatus Fr.

Hypomyces lactifluorum (Schw.) Tul.

Lentinus lepideus Fr.

Sporodinia grandis Link (?)

Mushroom

Eleutheromyces subulatus (Tode) Fckl.

Podosphaera Oxyacanthae (DC.) de Bary Ciccinobolus sp.

Polyporus versicolor (L.) Fr.

Hypomyces aurantius (Pers.) Tul.

Uredineae

Darluca filum (Biv.) Cast.
Valsa sp.

Nectria episphaeria (Tode) Fr.

Aphid (on sunflower)

Empusa Aphidis Hoffm.

Ctenucha virginica (N. sedge Moth)

Entomophthora Grylli

Dissoteira carolina (grasshopper) Entomophthora Gryli

Melanopus sp. (grasshopper)

Entomophthora Grylli

Musca domestica (house fly)

Empusa Muscae Cohn. 



\section{GENERAL INDEX}

Alfalfa............................ Pagk

Ascochyta Medicaginis Bres............... 15

Peronospora Trifoliorum de Bary........ 15

Pleosphaerulina Briosiana Pollacci....... 15

Pseudopeziza Medicaginis (Lib.) Sacc... 15

Pyrenopeziza Medicaginis Fckl......... 15

Sclerotinia Trifoliorum Eriks.......... 15

Uromyces Medicaginis Pass............. 15

White spot......................... 15

AMPELOPSIS (Ampelopsis quinquefolia Michx.) Uncinula necator (Schw.) E. et E.

Anthracnoses................... Appendix I

APPLE.

Armillaria mellea (Vahl.) Quél............

Bacillus amylovorus (Burr.) Trev.......

Bacillus tumefaciens E.F.S. et Town....

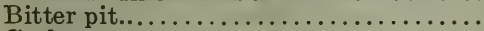

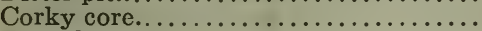

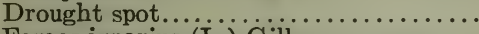

Fomes ignarius (i.) Gill.................

Gloeodes pomigena (Schw.) Colby.......

Glomerella cingulata (Stonem, S. et

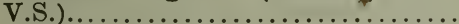

Gymnosporangium germinale (Schw.)

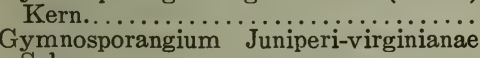

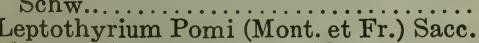

Myxosporium corticolum Edg...........

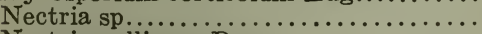

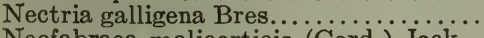

Neofabraea malicorticis (Cord.) Jack..

Phyllosticta sp.....................

Physalospora Cydoniae Arn...

Podosphaera leucotricha (E. et E.) Salm.

Sclerotinia americana (Wormald) Norton et Ezekiel

Sclerotinia cinerea (Bon.) Schr............

Sclerotinia fructicola (Wint.) Rehm......

Stereum purpureum Pers...............

Venturia inaequalis (Cke.) Wint..............

Winter injury........................

Apricot.

Silver leaf.$\ldots \ldots \ldots \ldots \ldots \ldots \ldots \ldots \ldots \ldots \ldots \ldots \ldots$

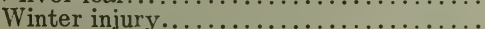

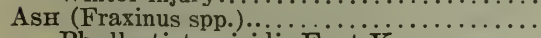

Phyllosticta viridis $\mathrm{E}$. et $\mathbf{K} \ldots \ldots \ldots \ldots \ldots$

Piggotia Fraxini B. et C...............

Septoria Besseyi Pk................

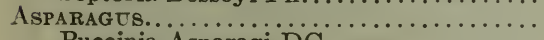

Puccinia Asparagi $\dddot{\mathrm{D}} \mathrm{C} . \ldots \ldots \ldots \ldots \ldots \ldots \ldots$

Rusty tips...............................
Aster (Callistephus chinensis Nees)

Coleosporium Solidaginis (Schw.) Thüm

Fusarium conglutinans Callistephi Beach

Sclerotinia libertiana Fckl.

Sclerotinia sclerotiorum (Lib.) Mass.....

Septoria Callistephi Gloyer.............

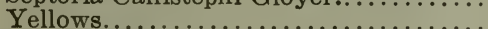

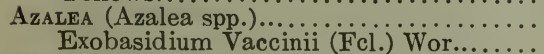

Balsam Fir (Abies balsamea (L.) Miller)...

Armillaria mellea (Vahl) Quél...........

Polyporus balsameus Pk..............

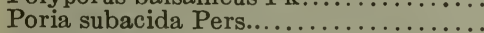

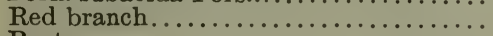

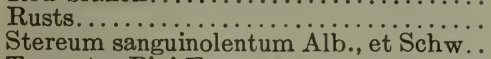

Trametes Pini Fr....................

BaRBERRY (Berberis spp.)...................

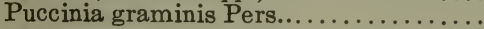

BARLEY

Bacterium translucens J. J. et $\mathrm{R} . . . \ldots \ldots$

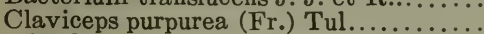

Dilophospora graminis Desm.............
BARLEY-Con.

Erysiphe graminis DC............. 13

False stripe........................ 13

Helminthosporium gramineum Rab.... 12

Helminthosporium sativum P.K. et B.. 13

Helminthosporium teres Sacc.......... 13

Puccinia glumarum (Schm.) Er. et Henn. 12

Puccinia graminis Pers............... 12

Puccinia simplex (Koern.) Eriks. et

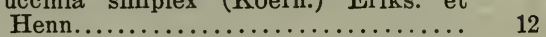

Rhynchosporium Secalis (Heins.) Davis. 13

Septoria Passerinii Sacc............... 13

Ustilago Hordei (Pers.) K. et S............ 12

Ustilago nuda (Jens.) K. et S........... 12

Basswood (Tilia americana L.)........... 48

Gloeosporium Tiliae Oud............ 48

BEAN............................................ 32

Colletotrichum Lindemuthianum (Sace. et Magn.) Br. et Cav.................

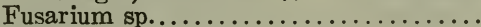

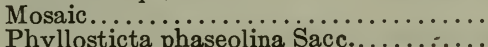
Rhizoctonia sp...................... Sclerotinia libertiana Fckl.................
Uromyces appendiculatus (Pers.) Lév..

Actinomyces scabies (Thax.) Güssow... 34

Cercospora beticola Sacc.............. 33

Phoma Betae Frank................. $\quad 33$

Rhizoctonia sp....................... 34

Birches (Betula alba var. papyrifera (Marsh) Spach. and Betula lutea Michx.)...... Fomes fomentarius Fr................

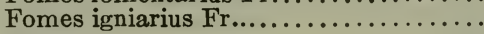

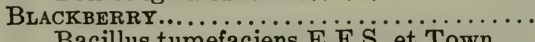
Bacillus tumefaciens E.F.S. et Town... Gloeosporium venetum Speg......... Mosaic.

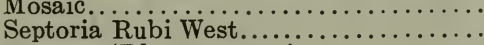

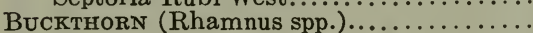
Puccinia coronata Cda..

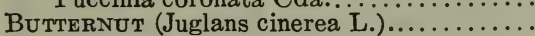

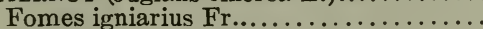

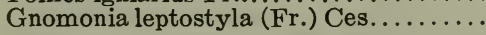

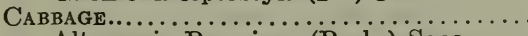

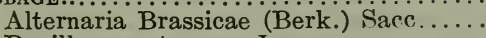
Bacillus carotovorus Jones.

Bacterium campestre (Pammel) E.F.S.

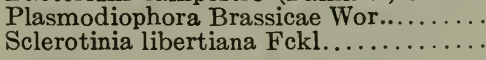

CANTALOUPE.

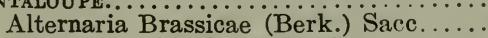
Bacillus tracheiphilus E.F.S.

Peronoplasmopara cubensis (B. et C.) Clint.

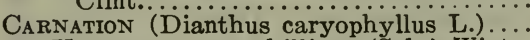
Uromyces caryophillinus (Sch.) Wint..

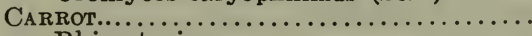

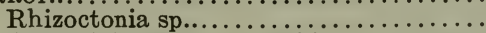
Sclerotinia libertiana Fckl.............

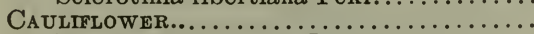
Bacillus carotovorus Jones............ Bacterium campestre (Pammel) E.F.S.

Cedar (Thuja occidentalis L.).............. Keithia thujina Durand..................

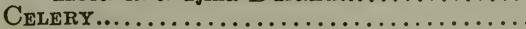

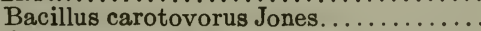

Cercospora Apii Fr..................

Fusarium sp.......................

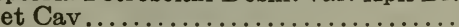

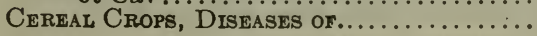


Cherry

Breakdown...................... 26

Coccomyces hiemalis Higgins........... 25

Coryneum Beijerinckii Oud............ 26

Exoascus Cerasi Fckl................. 25

Plowrigh via morbosa (Schw.) Sace..... 25

Podosphaera Oxyacanthae (Fr.) deB.... 25

Sclerotinia americana (Wormald) Norton

et Ezekiel........................

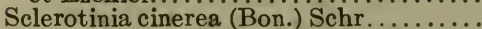

Sclerotinia fructicola (Wint.) Rehm.....

Winter injury.

Chestnut (Castanea dentata (Marsh)Borkh.) Endothia parasitica (Murr.) And.......

Chrysanthemum (Chrysanthemum spp.). .

Cylindrosporium Chrysanthemi Ell. et

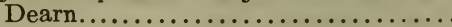

Clovers

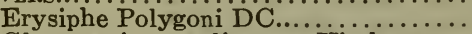

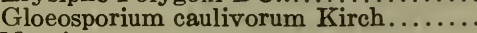

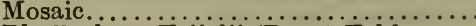

Phyllachora Trifolii (Pers.) Fckl........

Pseudopeziza Trifolii Fckl..............

Sclerotinia Trifoliorum Eriks...........

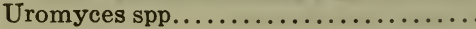

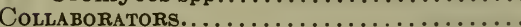

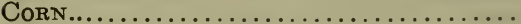

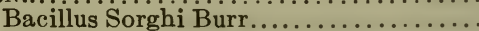

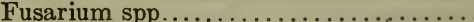

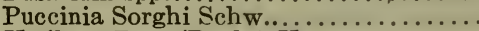

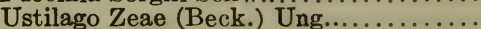

Crataegus (Crataegus spp.).

Gymnosporangium globosum Farl.......

Cucumber.

Bacillus tracheiphilus E.F.S...........

Bacterium lachrymans Sm. et Bryan...

Colletotrichum lagenarium (Pass.) E. et H...

Cladosporium cucumerinum Eil. et Arth. Fusarium sp......................... Mosaic.

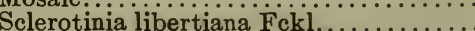

Currant.............

Cercospora angulata Wint.

Cronartium ribicola F. de Wald ..........

Mycosphaerella Grossulariae (Fr.) Lind.

Nectria cinnabarina (Tode) Fr.........

Pseudopeziza Ribis Kleb

Puccinia Pringsheimiana Kleb.

Sphaerotheca Mors-uvae (Schw.) B.et C.

Currant, Flowering (Ribes aureum Pursh.) Mycosphaerella aurea Stone........... Septoria aurea E. et E.

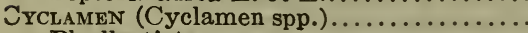

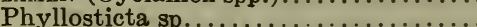
Thielavia basicola (B. et Br.) Zopf........

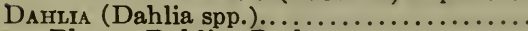
Phoma Dahliae Berk...

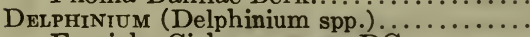
Erysiphe Cichoracearum DC..........

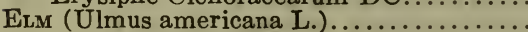

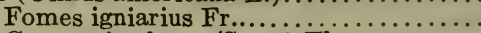

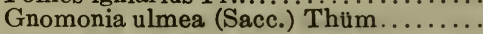

FLAX.

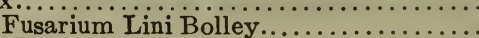
Heat canker.

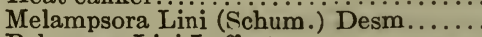
Polyspora Lini Lafferty..............

Forage and Fibre Crops, Diseases of.....

Forest and Shade Trees, Diseases of.....

Fruit Crops, Diseases of................

Gradiolus (Gladiolus spp.).

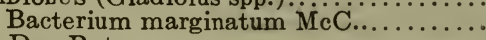
Dry Rot

Septoria Gladioli Pass..................

Gooseberry...................... (Fir) Lind. Pseudopeziza Ribis Kleb..............

Puccinia Pringsheimiana Kleb.............

Sphaerotheca Mors-uvae (Schw.) B. et

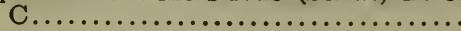

Grape........................................

27

Guignardia Bidwellii (Ell.) V. et R.... 27

Plasmopara viticola (B. et C.) Berl. et de

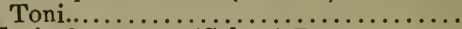

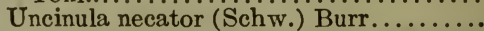

Grasses (Cu litrated) For wild grasses see under Miscellaneous Plants, Diseases

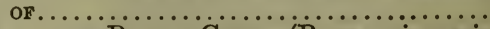

Awnless Brome Grass (Bromus inermis

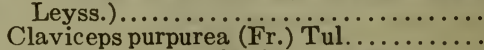

Puccinia Clematidis (DC. ) Lag..........

Septoria bromigena Sacc................
KeNtucky Bude Grass (Poa pratensis L.) Claviceps purpurea (Fr.) Tul............

Meadow Fescue Grass (Festuca elatior

Helminthosporium dictyoides Drechsler

ORChARD GRASS (Dactylis glomerata L.). Claviceps purpurea (Fr.) Tul..........

Puccinia graminis Pers.. $\ldots \ldots \ldots \ldots \ldots \ldots$
Perennial Rye Grass (Lolium perenne

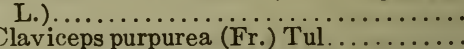

Claviceps purpurea (Fr.) Tul.............
Sudan Grass (Holcus Sorghum sudanensis

(Piper) Hitchc.).........................

Pseudomonas sp .......................

(L.) Beauv.)........................

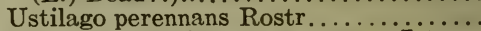

Timothy Grass (Phleum pratense $\mathrm{L}$. . .... Claviceps purpurea (Fr.) Tul............. Heterosporium Phlei Gregory...........

Puccinia graminis Phlei-pratensis Er. et

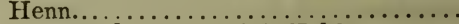

Scolecotrichum graminis Fckl...........

Western Rye Grass (Agropyron tenerum

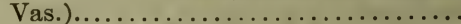
Claviceps purpurea (Fr.) Tul .............. Puccinia Clematidis (DC.) Lag........... Puccinia graminis Pers.................. Puccinia montanensis E. et $\mathrm{E} . \ldots \ldots \ldots$ Ustilago Agropyri Clinton. ..............

HoLLYносK (Althaea rosea Cav.) ............ Cercospora althaeina Sacc.............. Puccinia Malvacearum Mont...........

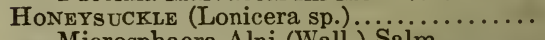
Microsphaera Alni (Wall.) Salm............

Horse Chestrut (Aesculus Hippocastanum

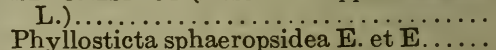

Horse Radish....................... Cercospora Armoraciae Sacc.............. Ramularia Armoraciae Fckl...........

INTRODUCTION........................

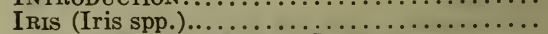

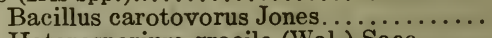
Heterosporium gracile (Wal.) Sacc......

IroNwood (Ostrya virginiana (Mill.) Koch).

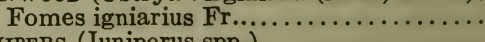

JuNIPERS (Juniperus spp.)................. Gymnosporangium globosum Farl...... Gymnosporangium juvenescens Kern....

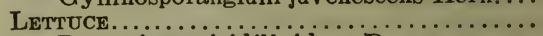

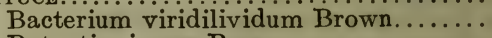

Botrytis cinerea Pers..................

Bremia Lactucae Regel....................

Marssonia Panattoniana (Beri.) Magnus.

Puccinia hieraciata (Schw.) Jackson....

Sclerotinia libertiana Fckl.............

Tip burn...........................

LILAC (Syringa vulgaris $\mathrm{L}$.) $\ldots \ldots \ldots \ldots \ldots \ldots \ldots$ Microsphaera Alni (Wali.) Salm .........

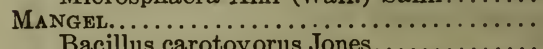
Bacillus carotovorus Jones........... Pacillus tumefaciens E.F.S. et Town....

Root blight.

Manitoba, Parasitic F pNai of. . Appendix II
27
27
17

17 


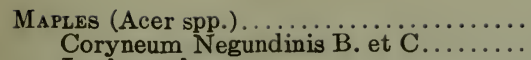

Page

Leaf scorch Phyllosticta minima (B...et C.) E. et E. Phyllosticta Negundinis Sacc. et Speg. Rhytisma acerinum Fr...............

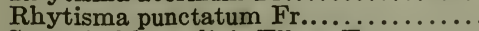
Septoria Negundinis Ell. et Ev........

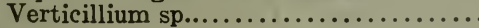

MrLlet.............................

Miscellaneous Plants, Diseases of.......... (In alphabetical order in the text)..... OAк (Quercus spp.)........................

$$
\text { Long.... }
$$

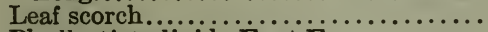
Phyllosticta livida E. et E................ Polyporus sulphureus Fr...............

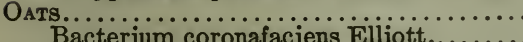
Blasting of heads.................... Colletotrichum cereale Manns........... Erysiphe graminis DC............... Fusarium sp....................................

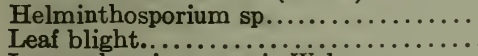

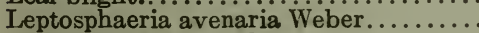

Puccinia coronata Cda................

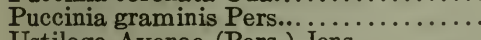

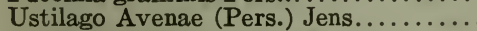

Ustilago levis (K. et S.) Magn...........

ONION.

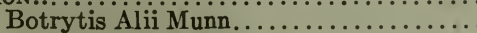

Fusarium Malli Taub.

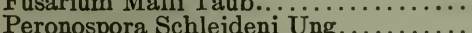

Urocystis Cepulae Frost..............

Ornamental Plants, Diseases of............

Pea

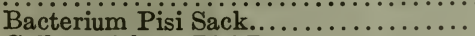

Colletotrichum Pisi Pat................

Erysiphe Polygoni DC..................

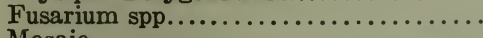

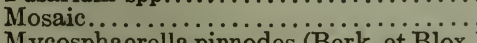

Mycosphaerella pinnodes (Berk. et Blox.)

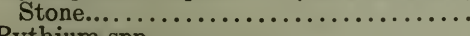

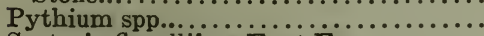

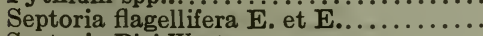

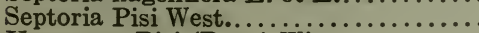

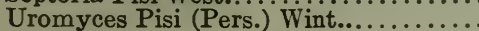

Peach.........................................

Bacterium Pruni E.F.S................

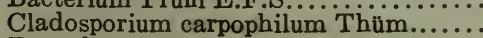

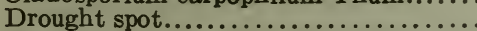

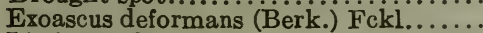

Little peach............................

Sclerotinia americana (Wormald) Norton

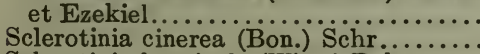
Sclerotinia fructicola (Wint.) Rehm...... Sphaerotheca pannosa (Wal.) Lév.......

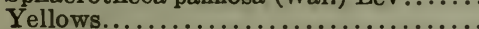

Pear............................................... Bacillus amylovorus (Burr.) Trev...... Core rot............................

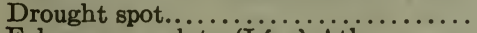
Fabraea maculata (íév.) Atk............ Mycosphaerella sentina (Fr.) Schr...... Podosphaera leucotricha (E. et E.) Salm Venturia pyrina Aderh.................

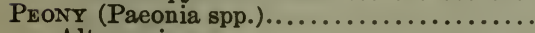

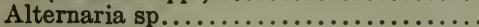

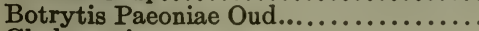

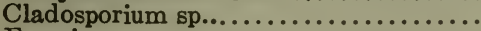

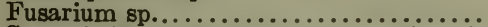
Septoria Paeoniae West var. berolinensis Allesch...........................
PAGE

PePper.............................. ${ }_{38}$

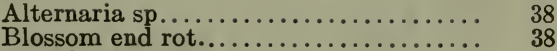

Phцox (Phlox spp.)......................... $\quad{ }_{56}$ Erysiphe Cichoracearum DC......... 56

Pines (Pinus spp.)................... 51 Cronartium cerebrum (Pk.) Hedgc. et Long........................ 52 Cronartium Comptoniae Ärth.............. 52 Cronartium pyriforme (Pk.) Hedgc. et Long.............................. 51 Cronartium ribicola $\mathbf{F}$. de Wald.......... 51 Needle blight...................... 51 Peridermium Harknessi Moore.......... 51 Trametes Pini Fr................. $\quad 51$

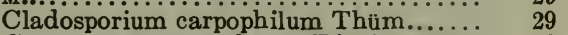
Coccomyces prunophorae Higgins....... 29 Drought spot...................... 29 Exoascus Pruni Fckl.................. 29 Plowrightia morbosa (Schw.) Sace..... 29 Sclerotinia americana (Wormald) Norton et Ezekiel.....

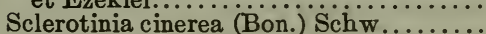
Sclerotinia fructicola (Wint.) Rehm.....

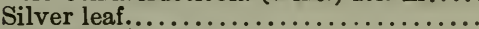

Poprars (Populus spp.). Cladosporium subsessile Ell. et Barth.. 52 Cytospora chrysosperma Pers.......... 52 Dothichiza populea Sacc. et Briard...... 52 Fomes igniarius Fr................. 52 Melampsora Medusae Thüm............... 52 Napicladium Tremulae (Frank) Sacc.. 52 Septoria musiva Pk................ 52

Actinomyces scabies (Thax). Güssow... 41 Alternaria Solani (E. et M.) J. et G..... 40 Armillaria mellea (Vahl) Quél......... 41 Arsenical injury.................... 43 Bacillus solanisaprus Har............. 41 Botrytis cinerea Pers................ 41 Bronzing ............................ 43 Colletotrichum tabificum (Hallier p.p.) Pethybridge.................... 41 Corticium vagum B. et C............... 40 Curly dwarf....................... 42 Fusarium oxysporum Schl............... 40 Hollow heart.................... 42 Hopper burn............................ 42 Leaf roll............................... 42 Mosaic.............................. 41 Net necrosis............................ 42 Oospora pustulans Owen et Wakf ........... 41 Phytophthora infestans (Mont.) de Bary 39 Sclerotinia libertiana Fckl........... 40 Sclerotinia sclerotiorum (Lib.) Mass.... 40 $\begin{array}{ll}\text { Spindling tuber...................... } & 42 \\ \text { Spondylocladium atrovirens Harz...... } & 40\end{array}$ $\begin{array}{ll}\text { Spondylocladium atrovirens Harz....... } & 40 \\ \text { Spongospora subterranea (Wallr.) Johns. } & 41\end{array}$ $\begin{array}{ll}\text { Spongospora subterranea (Wallr.) Johns. } & 41 \\ \text { Streak............................... } & 42\end{array}$ Tip burn................................. 42 Verticillium albo-atrum Reinke et Berth $\quad 40$

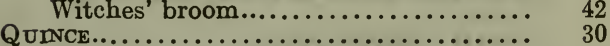
Fabraea maculata (Lév.) Atk......... 30 Gymnosporangium germinale (Schw.)

Kern.......................... 30

RasPBERRY..................... 30

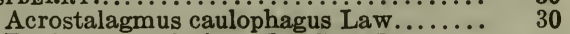
Bacillus tumefaciens E.F.S. et Town.... 31 Gloeosporium venetum Speg. ............ 30

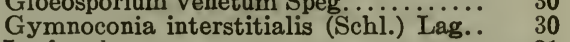
Leaf curl............................ 31 Sacc............................. 30 Mosaic.................................... 31 Mycosphaerella Rubi (West.) Roark.... 30 Mycosphaerella rubina (Pk.) Jacz....... 30 Phragmidium imitans Arth........... 31 
RASPBERRY-Con.

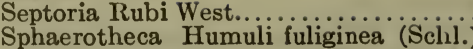

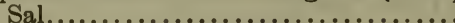

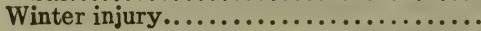

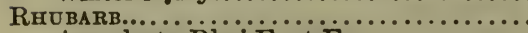

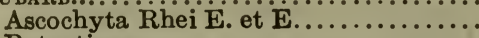

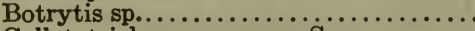

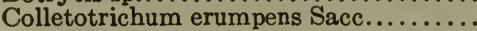

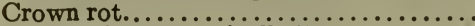

Phyllosticta straminella Bres............

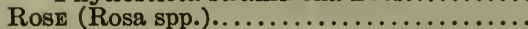
Bacterium tumefaciens E.F.S. et Town. Cercospora rosicola Pass................ Coniothyrium Wernsdorffiae Laubert.... Diplocarpon Rosae Wolf...............

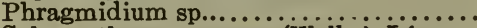
Sphaerotheca pannosa (Wailir.) Lêv....

RYE..

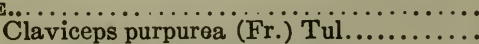

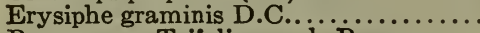
Peronospora Trifoliorum de Bary......... Puccinia dispersa Eriks............... Puccinia graminis Pers................. Urocystis occulta (Wallr.) Rab..........

Saskatoon BerRy (Amelanchier alnifolia

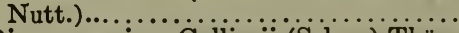
Dimerosporium Collinsii (Schw.) Thüm Gymnosporangium corniculans Kern....

SNAPDRAGON (Antirrhinum spp.)........... Puccinia Antirrhini D. et H.............

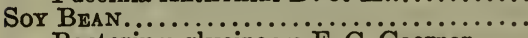

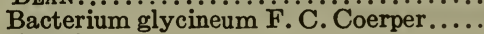
Fusarium sp........................ Mosaic

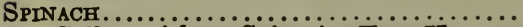
Colletotrichum Spinaciae E. et $\mathbf{H} . . . .$. Peronospora effusa (Grév.) Rab........ Puccinia subnitens Dietel...............

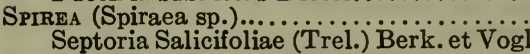

SpRUCE (Picea spp.)....................... Melampsoropsis abietina (A. et S.) Arth.

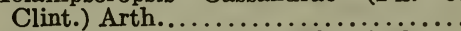
Melampsoropsis ledicola ( $\mathrm{Pk}$.) Arth.... Red branch........................

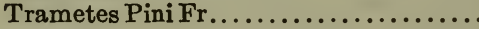

STRA WBERRY...$\ldots \ldots \ldots \ldots \ldots \ldots \ldots \ldots \ldots \ldots \ldots$

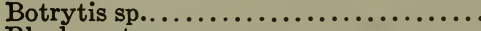

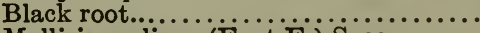

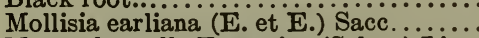
Mycosphaerella Fragariae (Schw.) Lin... Rhizopus sp.......................

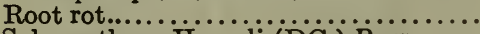

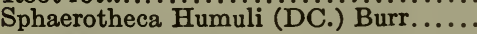

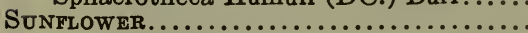

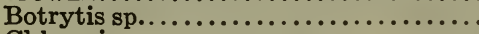

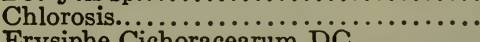

Erysiphe Cichoracearum DC Plasmopara Halstedii (Farl.) Berl. et de Plasmopara Halstedii (Farl.) Berl. et de

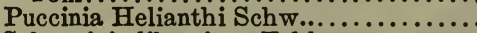
Sclerotinia libertiana Fckl.............. Sclerotinia sclerotiorum (Lib.) Mass.... Septoria Helianthi E. et K..............

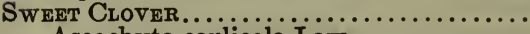
Ascochyta caulicola

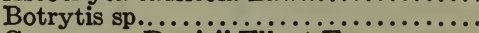
Cercospora Davisii Eil. et Ev..............

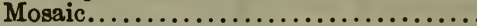

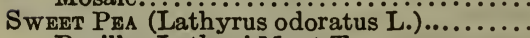
Bacillus Lathyri M. et T................

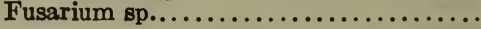

PAGE
Sweet Pea-Con.

P.IGE

Microsphaera Alni (Wallr.) Salm....... Mosaic.

Товассо .

Bacterium angulatum Fromme et Mur-

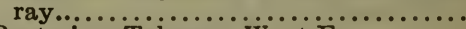

Bacterium Tabacum W. et $\mathbf{F} . . . . . . . . .$.

Early blossoming.....................

Fertilizer burn.........................

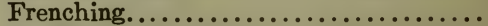

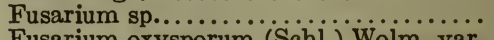

Fusarium oxysporum (Schl.) Wolm. var.

Nicotianae John...................

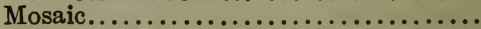

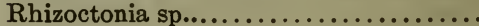

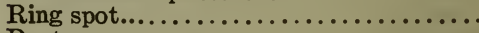

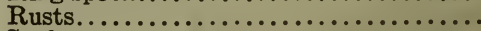

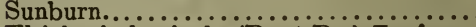

Thielavia basicola (B. et Br.) Żopf.....

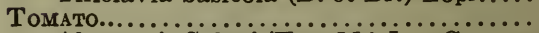

Alternaria Solani (E. et M.) J. et G........

Aplanobacter michiganense E.F.S......

Blossom end rot.

Cladosporium fulvum Cke..............

Colletotrichum phomoides (Sacc.) Chest

Mosaic.

Phytophthora infestans (Mont.) de Bary

Phytophthora terrestris Sherb..........

Sclerotinia libertiana Fckl.............

Sclerotinia sclerotiorum (Lib.) Mass....

Septoria Lycopersici Speg..............

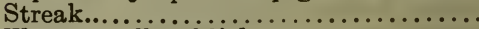

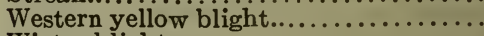

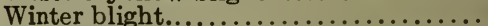

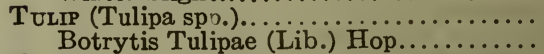

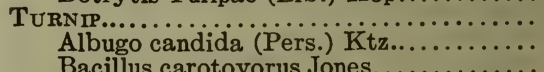
Bacterium campestre (Pammel) E.F.S.

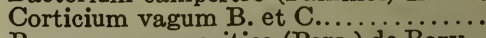
Peronospora parasitica (Pers.) de Bary. Plasmodiophora Brassicae Wor.......... Storage rots.

Vegetable and Field Crops, Diseases of...

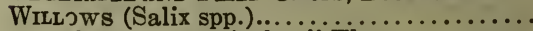

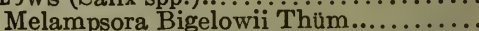
Melampsora confluens (Pers.) Jackson... Rhytisma salicinum Fr............... Uncinula Salicis (DC.) Winter.............

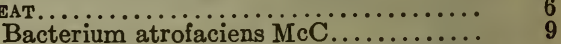

Bacterium translucens undulosum S..... et $R . . . \ldots \ldots \ldots \ldots \ldots \ldots \ldots \ldots \ldots \ldots$.

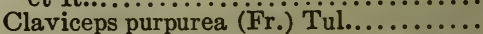
Erysiphe graminis DC................ Frost injury......................... Fusarium spp........ $\ldots \ldots \ldots \ldots \ldots$

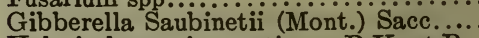
Helminthosporium sativum P.K. et B... Helminthosporium spp................ Krinkle joint......................

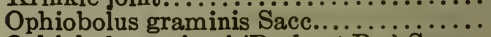
Ophiobolus cariceti (Berk. et Br.) Sacc... Puccinia glumarum (Schum.) E. et H.. Puccinia graminis Pers................. Puccinia triticina Eriks................ Septoria nodorum Berk................ Septoria Tritici Desm............... Tilletia laevis Kuhn ................... Tilletia Tritici (Bjerk.) Wint............... Ustilago Tritici (Pers.) Jens.............. White tip.............................. Wojnowicia graminis (MicAilp.) Sacc. et
D. Sacc........................... 


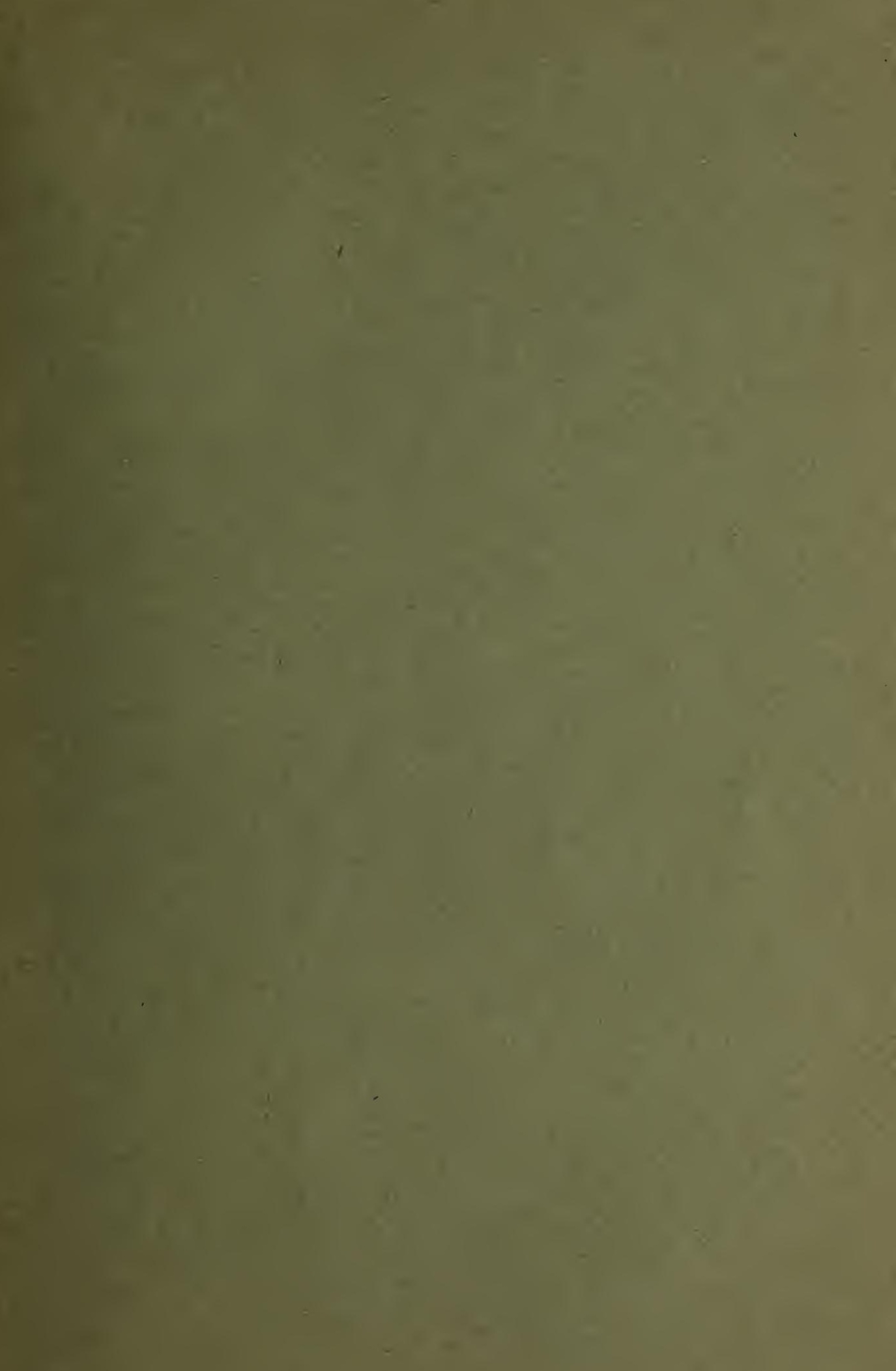


